\title{
ANDROGEN RECEPTOR PHOSPHORYLATION
}

\author{
ANDROGEENRECEPTOR FOSFORYLERING
}

\section{PROEFSCHRIFT}

ter verkrijging van de graad van doctor

aan de Erasmus Universiteit Rotterdam

op gezag van de Rector Magnificus

prof.dr. P.W.C. Akkermans M.A.

en volgens besluit van het College voor Promoties.

De openbare verdediging zal plaatsvinden op

woensdag 12 april 1995 om 13.45 uur

door

Georgius Gerardus Johannes Maria Kuiper

geboren te Maastricht 


\title{
PROMOTIECOMMISSIE
}

\author{
Promotor: \\ Prof. dr. J.A. Grootegoed \\ Co-promotor: \\ Dr. A.O. Brinkmann \\ Overige leden: \\ Prof. dr. G. Verhoeven \\ Dr. H.R. de Jonge \\ Prof. dr. ir. Th.J. Visser
}

Dit proefschrift werd bewerkt binnen het Instituut Endocrinologie \& Voortplanting van de Faculteit der Geneeskunde en Gezondheidswetenschappen, Erasmus Universiteit Rotterdam.<smiles>C1CCC1</smiles>

Gedrukt bij Offsetdrukkerij Ridderprint B.V., Ridderkerk 


\section{CONTENTS}

ABBREVIATIONS 5

SCOPE OF THIS THESIS

SUMMARY

SAMENVATTING 11

$\begin{array}{lll}\text { CHAPTER } 1 & \text { THE ANDROGEN RECEPTOR } & 13\end{array}$

$\begin{array}{lll}1.1 & \text { Introduction } & 14\end{array}$

1.2 Demonstration of the androgen receptor 14

1.3 Characterization and purification of the androgen receptor 16

1.4 Structure of the androgen receptor 20

$1.5 \quad$ Interaction of the androgen receptor with target genes 25

1.6 Conclusions 31

CHAPTER 2 STEROID HORMONE RECEPTOR PHOSPHORYLATION 33

2.1 Introduction 34

$2.2 \quad$ Indirect evidence for a role of steroid hormone receptor 35

phosphorylation

2.3 Basal and hormone-dependent phosphorylation of steroid 38 receptors

2.4 Location of phosphorylation sites in steroid hormone 42

receptor proteins

$2.5 \quad$ Identification of phosphorylation sites 43

2.6 Protein kinases involved in steroid hormone receptor 46

phosphorylation

$2.7 \quad$ Steroid hormone receptor phosphorylation and receptor 48

function

$\begin{array}{lll}2.8 & \text { Conclusions } & 57\end{array}$

$\begin{array}{ll}\text { REFERENCES } & 63\end{array}$ 
CHAPTER 3

CHAPTER 4

CHAPTER 5

CHAPTER 6

CHAPTER 7

7.1

7.2

7.3

7.4
SYNTHESIS AND POST-TRANSLATIONAL MODIFICATION OF THE ANDROGEN

RECEPTOR IN LNCaP CELLS

LOCALIZATION AND HORMONAL STIMULATION OF PHOSPHORYLATION SITES IN THE LNCaP CELL ANDROGEN RECEPTOR

PHOSPHOTRYPTIC PEPTIDE ANALYSIS OF THE HUMAN ANDROGEN RECEPTOR: DETECTION OF A HORMONE-INDUCED PHOSPHOPEPTIDE

IN VITRO TRANSLATION OF ANDROGEN

RECEPTOR cRNA RESULTS IN AN

ACTIVATED ANDROGEN RECEPTOR PROTEIN 


\section{ABBREVIATIONS}

\begin{tabular}{|c|c|}
\hline Ala & alanine \\
\hline AR & androgen receptor \\
\hline ARE & androgen responsive element \\
\hline ATP & adenosine $5^{\prime}$-triphosphate \\
\hline BSA & bovine serum albumin \\
\hline cAMP & adenosine $3^{\prime}: 5^{\prime}$-cyclic-monophosphate \\
\hline (c)DNA & (complementary) deoxyribonucleic acid \\
\hline $\mathrm{CHO}$ & chinese hamster ovary cell line \\
\hline $\operatorname{COS}$ & monkey kidney cell line \\
\hline cpm & counts per minute \\
\hline $\mathrm{CV}-1$ & monkey kidney cell line \\
\hline $\mathrm{DHT}$ & 50 -dihydrotestosterone ( $17 \beta$-hydroxy-5 $\alpha$-androstan- 3 -one) \\
\hline DOC & sodium deoxycholate \\
\hline $\mathrm{dpm}$ & disintegrations per minute \\
\hline DTT & dithiothreitol \\
\hline EDTA & ethylenediaminetetra acetic acid \\
\hline GRE & glucocorticoid responsive element \\
\hline HeLa & human cervix carcinoma cell line \\
\hline HPLC & high performance liquid chromatography \\
\hline HRE & hormone responsive element \\
\hline hsp70 & $70 \mathrm{kDa}$ heat-shock protein \\
\hline hsp90 & $90 \mathrm{kDa}$ heat-shock protein \\
\hline $\mathrm{kDa}$ & kilo Dalton \\
\hline $\mathrm{LNCaP}$ & lymph node carcinoma of the prostate \\
\hline MEM & minimum essential medium \\
\hline mibolerone & $7 \alpha-17 \alpha$-dimethyl-19-nortestosterone \\
\hline MMTV.LTR & mouse mammary tumor virus long terminal repeat \\
\hline (m)RNA & (messenger) ribonucleic acid \\
\hline NMR & nuclear magnetic resonance \\
\hline PAGE & polyacrylamide gel electrophoresis \\
\hline PCR & polymerase chain reaction \\
\hline PMSF & phenylmethylsulfonyl fluoride \\
\hline $\mathrm{R} 1881$ & $17 \beta$-hydroxy-17 $\alpha$-methyl-4,9,11-estratrien-3-one \\
\hline RPMI & Roswell Park Memorial Institute \\
\hline$S$ & Svedberg unit \\
\hline SDS & sodium dodecylsulphate \\
\hline Ser & serine \\
\hline $\mathrm{T}$ & testosterone (17 $\beta$-hydroxy-4-androsten-3-one) \\
\hline $\mathrm{T} 47 \mathrm{D}$ & mammary tumor cell line \\
\hline TCA & trichloroacetic acid \\
\hline Thr & threonine \\
\hline TFA & trifluoroacetic acid \\
\hline TLC & thin layer chromatography \\
\hline TLCK & N-tosyl-L-lysine-chloromethyl ketone \\
\hline TPCK & $\mathrm{N}$-tosyl-L-phenylalanine chloromethyl ketone \\
\hline
\end{tabular}




\section{SCOPE OF THIS THESIS}

Steroid hormone receptors are trans-acting gene regulatory proteins, involved in the accomplishment of steroid hormone-induced cellular responses. Upon binding of hormone, the receptor-hormone complex undergoes a conformational change, which is thought to precede binding of the complex to hormone responsive elements in the target cell genome. This results in the up- or downregulation of the expression of target genes. Hence steroid hormone receptors can be viewed as ligand-activated transcription factors. The activities of transcription factors are often regulated through protein phosphorylation. Evidence has been provided that progesterone, glucocorticoid, estrogen, 1,25dihydroxyvitamin $D_{3}$, and androgen receptors also exist as phosphoproteins in the cell.

The aim of the work presented in this thesis was to gain more insight in the possible functional role of androgen receptor phosphorylation.

To achieve this goal, studies were carried out to determine in detail the effect of ligand binding on androgen receptor phosphorylation, and attempts were made to identify individual receptor phosphorylation sites.

After an introduction on the role of the androgen receptor in the mechanism of action of androgens, and a detailed overview of steroid receptor phosphorylation (Chapters 1 and 2), investigations are described on androgen receptor protein heterogeneity, on the location of phosphorylation sites in the androgen receptor, and on the effect of ligand on androgen receptor phosphorylation (Chapters 3 to 6 ).

Finally, various possible functional roles of androgen receptor phosphorylation are considered (Chapter 7). 



\section{SUMMARY}

Many physiological processes in organisms are regulated by a relatively small number of steroid hormones. Androgens are the so-called male sex steroid hormones which control growth, differentiation and functions of male reproductive and accessory sex tissues. Androgens are mainly produced in the testis and circulate in the blood. They diffuse in and out of all cells, but are retained with high affinity and specificity in target cells by an intranuclear binding protein, termed the androgen receptor. Once bound by androgens, the androgen receptor undergoes a conformational change allowing the receptor to bind with high affinity to DNA and to modulate transcription of certain genes. The androgen receptor appears to be a transcription factor, regulated by androgenic steroids. Phosphorylation is the predominant cellular mechanism for reversible modification of proteins, and the fact that many transcription factors are phosphoproteins suggests a regulatory role of phosphorylation. In this thesis, studies on phosphorylation of the androgen receptor in human prostate tumor cells (LNCaP) are described. In LNCaP cells, the androgen receptor protein is present as two isoforms with apparent molecular masses of 110 and $112 \mathrm{kDa}$ during SDS-PAGE. The $112 \mathrm{kDa}$ isoform reflects the phosphorylated receptor, whereas the $110 \mathrm{kDa}$ isoform is the non-phosphorylated receptor. Both isoforms are able to bind androgens with high affinity and can subsequently be transformed to the DNA binding form. It appears to be unlikely that phosphorylation is involved in the regulation of steroid- or DNA binding affinity. Upon incubation of the prostate tumor cells with androgens, the phosphorylation degree of the androgen receptor was rapidly increased. Multiple phosphorylation sites on serine residues are located in the N-terminal transactivation domain and not in the DNA- and ligand binding domains. Tryptic phosphopeptide maps of the androgen receptor show induction of 
phosphorylation at a novel site(s) by hormone treatment. It is proposed that this extra phosphorylation in the $\mathrm{N}$-terminal domain causes a conformational change, enabling protein-protein contacts of the trans-activation domain with other transcription factors or co-activators on a target gene promoter. 


\section{SAMENVATTING}

De steroidhormonen testosteron en 50-dihydrotestosteron (androgenen) zijn betrokken bij de ontwikkeling en het behoud van de mannelijke geslachtskenmerken, inclusief de vorming van zaadcellen. Androgenen oefenen hun werking uit door binding aan een eiwit, de androgeenreceptor, dat aanwezig is in de kern van androgeen doelwitcellen. Binding van androgenen aan de receptor geeft aanleiding tot een aantal structurele veranderingen in het receptor eiwit, waardoor dit in staat is een interactie aan te gaan met bepaalde DNA sequenties in het promotor gebied van androgeen doelwitgenen. Dit resulteert uiteindelijk in stimulatie of remming van de transcriptie van gereguleerde genen. De androgeenreceptor kan dan ook opgevat worden als een hormoon-gereguleerde transcriptiefactor.

Fosforylering is een van de belangrijkste modificaties die eiwitten in de cel kunnen ondergaan, en het feit dat vele transcriptiefactoren fosfo-eiwitten zijn doet vermoeden dat fosforylering betrokken is bij de regulatie van de funktie van deze eiwitten. Ook de androgeenreceptor is een fosfo-eiwit. In dit proefschrift is de fosforylering van de androgeenreceptor in prostaat tumorcellen onderzocht. De androgeenreceptor is in deze cellen aanwezig als twee isovormen met molecuulmassa's van 110 en $112 \mathrm{kDa}$, zoals blijkt na SDS-PAGE. De 112 $\mathrm{kDa}$ isovorm ontstaat uit de $110 \mathrm{kDa}$ isovorm door fosforylering. Beide isovormen zijn in staat om specifiek androgenen te binden, en ondergaan in de cel vervolgens een transformatie tot de DNA bindende vorm. Incubatie van prostaat tumorcellen met androgenen heeft een snelle toename van de fosforyleringsgraad van de androgeenreceptor tot gevolg. Bij nadere analyse blijkt dat de androgeen- receptor uitsluitend fosforylering ondergaat op serine residuen, en wel in het aminoterminale trans-activatie domein. Tevens blijkt dat hormoonbinding de fosforylering op één of meer nog niet gefosforyleerde serine 
residue(n) tot gevolg heeft, terwijl de fosforyleringsgraad van andere plaatsen niet of nauwelijks verandert. Het is zeer goed mogelijk dat de hormoongestimuleerde fosforylering de trans-activatie capaciteit van de androgeenreceptor (mede)-bepaalt. 


\section{CHAPTER 1}

\section{THE ANDROGEN RECEPTOR}




\subsection{Introduction}

Many physiological processes in organisms are regulated by a relatively small number of steroid hormones, all synthesized from cholesterol. Being small hydrophobic molecules, they are thought to be able to cross the plasma membrane of the cell by simple diffusion. In the cell, steroid hormones bind to specific intracellular receptor proteins, converting these proteins to functional transcription factors, which are then able to regulate in the nucleus the expression of specific genes (Jensen and DeSombre, 1973). The steroid hormones include gonadal hormones (estrogens, progestins and androgens) and adrenal cortical hormones (glucocorticoids and mineralocorticoids). This chapter is devoted to the mechanism of action of androgens and to the androgen receptor. Androgens (testosterone and 5 $\alpha$-dihydrotestosterone) control the growth, differentiation and function of reproductive and accessory sex tissues in the male, such as the prostate, epididymis, seminal vesicle, vas deferens, and penis. They also influence many other tissues such as skin, bone marrow, hair follicles, pituitary gland, hypothalamus, and behavioural centers in the brain. Testosterone (T) is, in combination with follicle-stimulating hormone (FSH), required for the initiation and maintenance of normal spermatogenesis (Marshall and Nieschlag, 1987; Roberts and Zirkin, 1991). Most prostate tumors are initially androgen dependent, and tumor growth can be arrested by removal of circulating androgens. However, at a later stage these prostate tumors usually become androgen independent and start growing again (Menon and Walsh, 1979).

\subsection{Demonstration of the androgen receptor}

Early attempts to demonstrate selective uptake and retention of androgens in 
vivo, using ${ }^{14} \mathrm{C}$-labeled steroids with low' specific activity, did reveal some accumulation of androgens in target organs of the rat, such as the prostate and seminal vesicles, in comparison with other tissues (Harding and Samuels, 1962). Only when $T$ labeled with tritium of high specific activity became available, a significant affinity of androgens for their target tissues could be demonstrated in vivo. In the period 1967-1969, the selective accumulation of ${ }^{3} \mathrm{H}$-testosterone or metabolites thereof in the prostate and seminal vesicles of the guinea pig and rat, was described (Resko et al., 1967; Anderson and Liao, 1968; Bruchovsky and Wilson, 1968; Mainwaring, 1969). The ${ }^{3} \mathrm{H}$-labeled steroid was found mainly in the nucleus, as was shown by subcellular fractionation and by dry-mount autoradiography (Anderson and Liao, 1968; Sar et al., 1970). An important advance in the understanding of the interaction of androgenic steroids with target tissues came with the discovery that the radioactivity which bound specifically in the prostate and in the seminal vesicles was not T but DHT (Anderson and Liao, 1968; Bruchovsky and Wilson, 1968). Reduction of T to DHT takes place in many target tissues but also in non-target tissues. However, some androgen responsive tissues in the human, such as muscle and the wolffian duct, show little capacity to reduce $\mathrm{T}$ to DHT, and in these organs $\mathrm{T}$ itself appears to interact directly with the receptor (Bardin and Catterall, 1981). The discovery that several sexual behavioural responses in the rat are stimulated by $\mathrm{T}$ but not by DHT, suggested that $\mathrm{T}$ acts directly on the androgen receptor in the brain. However, this situation is complicated by the fact that T, unlike DHT, is converted in the brain to estrogen which may produce the response (Sheridan, 1991, and references therein). DHT is responsible for virilization of the urogenital sinus and genital folds during embryogenesis, and for the development of most male secondary sex characteristics during puberty (Griffin and Wilson, 1992). DHT binds more tightly to the androgen receptor than T, and formation of DHT might therefore serve as an amplifying mechanism for 
androgen action (Griffin and Wilson, 1992).

The DHT bound in nuclei of rat prostate exposed to T either in vivo or during tissue incubations, could be extracted with salt containing buffers as part of a complex sedimenting at $3 \mathrm{~S}$ in sucrose density gradients (Liao and Fang, 1969). Cytosolic fractions of prostate contained a complex of 8-9S which dissociated to $3.5 \mathrm{~S}$ by salt treatment (Liao and Fang, 1969, and references therein). These studies provided the first evidence for the existence of androgen receptor protein. The uptake of androgenic steroids into nuclei of minced prostatic tissue was found to be strongly temperature dependent, with essentially no uptake taking place at $0-2^{\circ} \mathrm{C}$ (Liao and Fang, 1969). Isolated nuclei from rat prostate or epididymis incubated at $37^{\circ} \mathrm{C}$ did not bind androgenic steroids. However, after the addition of cytosol to the incubation mixture the formation of an extractable 3S complex containing DHT was reported (Liao and Fang, 1969, and references therein). Further studies showed that cytosols from a variety of androgen target tissues promote the binding of ${ }^{3} \mathrm{H}$-DHT to isolated chromatin (Mainwaring and Peterken, 1971). From these and many other studies it was concluded that androgen receptor complexes bound in target cell nuclei to chromatin, are derived from an initial complex formed in the cytoplasm, and that hormone binding is essential for the conversion of the receptor to a form that has high affinity for chromatin. This process, which was also described for the other steroid hormone receptors, was termed transformation (Gorski et al. 1968).

\subsection{Characterization and purification of the androgen receptor}

Upon homogenization in hypotonic buffers, the cytoplasmic androgen receptor from rat prostate has sedimentation coefficients between $7 \mathrm{~S}$ and $12 \mathrm{~S}$ (Liao et al., 1975). These large forms can be converted to the slower sedimenting 3-5S forms by incubation at $20-30^{\circ} \mathrm{C}$ or by raising the salt concentration to $0.4 \mathrm{M} \mathrm{KCl}$ 
(Mulder et al., 1983; Tindall et al., 1984). Also from human prostate tissue, human genital skin fibroblasts, human hyperplastic prostate tissue, sheep seminal vesicle, and calf uterine tissue, androgen receptors with similar properties could be isolated (Foekens et al., 1981; Kovacs et al., 1983; Wilbert et al., 1983; Murthy et al., 1984; de Boer et al., 1986A). Steroid binding was specific for androgens, and the affinity decreased in the sequence R1881 (methyltrienolone, a synthetic steroid) $>$ DHT $>$ T $>>$ progesterone $>$ estradiol $>$ cortisol (Bonne and Raynaud, 1975; Murthy et al., 1984). Androgen receptors have a high affinity for $\mathrm{DHT}$ and $\mathrm{T}(\mathrm{Kd} \sim 0.5 \mathrm{nM}$ ), and a finite binding capacity. A protein fraction designated " $8 \mathrm{~S}$ androgen receptor promoting factor", that promoted the conversion of the 3-5S androgen receptor to the $8 \mathrm{~S}$ androgen receptor form, was purified and found to inhibit the binding of the 3-5S androgen receptor to isolated nuclei and DNA cellulose in a concentration dependent manner (Colvard and Wilson, 1981; Colvard and Wilson, 1984). This study and others supported the hypothesis that the $8 \mathrm{~S}$ androgen receptor is a complex of the $3-5 \mathrm{~S}$ androgen receptor monomer with a non-steroid binding protein that renders the receptor incapable of binding to nuclei and DNA. Molybdate was found to stabilize the 8-10S androgen receptor forms in vitro (Rowley et al., 1984; de Boer et al., 1986B). The transition of the molybdate-stabilized 8-10S non-transformed receptor form into the transformed receptor (DNA binding form) is accompanied by a decrease in sedimentation value to $4 S$ (Kovacs et al., 1983; de Boer et al., 1986A; Wilson et al., 1986; Colvard and Wilson, 1987). Transformation can be accomplished in vitro by treatment with salt, ammonium sulphate precipitation of cytosols, or incubation of cytosols at $20-30^{\circ} \mathrm{C}$, and is associated with a strong increase in DNA cellulose binding capacity (Kovacs et al., 1983; de Boer et al., 1986B; Wilson et al., 1986). In-cell free binding experiments, transformed androgen receptors of rat ventral prostate cytosol bound with high affinity $(\mathrm{Kd}$ $\sim 0.1 \mathrm{nM}$ ) to a saturable number of binding sites associated with the nuclear 
matrix of the prostate. This binding was relatively high in prostate, but liver nuclear matrix, in contrast, contained only $15 \%$ of the sites found in the prostate nuclear matrix (Barrack, 1983; Buttyan et al., 1983; Colvard and Wilson, 1984).

Purification to homogeneity of the androgen receptor appeared to be a very difficult task, largely due to the relatively low expression level of androgen receptor protein in target tissues. In addition, the androgen receptor appeared to be very sensitive to proteolytic degradation. Two approaches have been used for the purification of the androgen receptor: differential chromatography with polyanion resins, and steroid affinity chromatography. In the first approach selective adsorption of the transformed androgen receptor by polyanions as DNA cellulose, phosphocellulose, heparin agarose, and ADP-sepharose is used after elimination of contaminating proteins, using the low affinity of non-transformed receptor for polyanions. Using chromatography on polyanion matrices a considerable purification of the androgen receptor from sheep seminal vesicle, calf uterus and rat prostate could be obtained (Mulder et al., 1979; Foekens et al., 1982; Mulder et al., 1985; van Loon et al., 1988). A complete purification of androgen receptor of rat ventral prostate was obtained by the introduction of a steroid affinity chromatography step after the polyanion chromatography steps (Chang et al., 1983; Davies and Thomas, 1984). The androgen receptor was purified approximately 120,000 fold and silver nitrate staining of a SDS-PAGE gel revealed a major polypeptide band migrating at 86,000 dalton (Chang et al. 1983).

Affinity labeling of the androgen receptor was used during various purification protocols to determine the molecular mass of the androgen receptor under denaturing (SDS-PAGE) conditions. Affinity labeling of steroid binding proteins can be performed either through electrophilic steroid affinity labels or through 
photoactivation of highly conjugated synthetic steroid ligands (Katzenellenbogen et al., 1984; Gronemeyer and Govindan, 1986). Affinity labeling with the low affinity ligand $\left[{ }^{3} \mathrm{H}\right]$-dihydrotestosterone $17 \beta$-bromoacetate revealed a molecular mass of 86,000 dalton under denaturing conditions for the androgen receptor of rat prostate and of 118,000 dalton for the receptor in the R3327 Dunning prostate tumor (Chang et al., 1984; Rowley et al., 1984). Photoaffinity labeling of the androgen receptor with $\left[{ }^{3} \mathrm{H}\right]$-methyltrienolone (R1881) from calf uterine tissue, human genital skin fibroblasts and prostatic tumor cells (LNCaP cells), revealed molecular masses of $85,000-110,000$ dalton under denaturing conditions (Brinkmann et al., 1985; Gyorki et al., 1986; Stamatiadis et al., 1987; Brinkmann et al., 1988; Gyorki et al., 1988). Limited proteolysis of androgen receptors by various proteases in vitro, and characterization of the resulting receptor fragments with regard to ligand- and DNA binding properties, revealed three different receptor domains, which are involved in steroid binding, DNA binding, and modulation of DNA binding (de Boer et al., 1987).

Because of the great difficulties in purifying the androgen receptor in sufficient amounts to serve as an immunogen, antibodies became only available with delay, in comparison with other steroid receptors. A surprise was the discovery of autoantibodies in the blood of patients with prostatic disease (Liao and Witte, 1985). The antibodies from serum samples were associated with a purified IgG fraction, and interacted with the $3.8 \mathrm{~S}$ cytosolic androgen receptor complexes of rat ventral prostate to form 9 to $12 \mathrm{~S}$ units. The antibodies interacted with the nuclear and cytosolic androgen receptor, either the DNA binding or the nonDNA binding form, but not with receptors for estrogen, progesterone or cortisol from several sources. By immortalizing blood lymphocytes of similar patients, cell lines were developed that produced monoclonal antibodies that reacted with human and rat androgen receptors. These antibodies identified the human 
androgen receptor as an $118 \mathrm{kDa}$ protein on Western blots (Young et al., 1988).

\subsection{Structure of the androgen receptor}

With the availability of purified progesterone-, estrogen-, and glucocorticoid receptors, and of specific antibodies that reacted with these proteins, it became possible to clone and express the cDNAs encoding these receptors. The amino acid sequence of these receptors was deduced from the nucleotide sequences of the respective cDNA clones. Expression cloning was carried out for the glucocorticoid receptor from human (Hollenberg et al., 1985; Govindan et al., 1985), rat (Miesfeld et al., 1986) and mouse (Danielsen et al., 1986), and for the human estrogen receptor (Green et al., 1986). In the same way the cDNAs for the progesterone receptor from rabbit (Loosfelt et al., 1986), chicken (Conneely et al., 1986; Gronemeyer et al., 1987) and human (Misrahi et al., 1987) were cloned. On the basis of the highly homologous sequences encoding the DNA binding domain of related receptors, it was assumed that the androgen receptor DNA binding domain would fall in the group that also contains the glucocorticoid, estrogen, and progesterone receptor. Using oligonucleotides corresponding to the most conserved region of the DNA binding domain, several investigators independently cloned the androgen receptor. First the human androgen receptor was cloned (Chang et al., 1988A; Chang et al., 1988B; Lubahn et al., 1988A; Lubahn et al., 1988B; Trapman et al., 1988; Faber et al., 1989; Tilley et al., 1989) and the rat androgen receptor (Chang et al., 1988B; Tan et al., 1988). Later the mouse androgen receptor was cloned (Gaspar et al,, 1990; He et al., 1990; Faber et al., 1991A).

The open reading frame of the human androgen receptor cDNA encodes a 
protein of 910-919 amino acid residues, with a calculated molecular mass of 99 kDa (Chang et al., 1988B; Lubahn et al 1988B; Brinkmann et al., 1989; Tilley et al., 1989). The $\mathrm{N}$-terminal domain of the androgen receptor contains a variety of homopolymeric amino acid stretches, most notably glutamine and glycine stretches. For the human androgen receptor there is an intraspecies variation in the length of these stretches, resulting in variation in the length of the androgen receptor protein (910-919 amino acid residues) (Sleddens et al., 1992). The human androgen receptor gene has been localized on the $\mathrm{X}$ chromosome (Lubahn et al., 1988A; Trapman et al., 1988; Brown et al., 1989). The coding part of the gene is distributed over 8 exons. Based on the homology with other steroid receptors, it was concluded that the first exon encodes the whole $\mathrm{N}$ terminal domain, exons 2 and 3 the DNA binding domain, while the information for the ligand binding domain is split over exons 4 to 8 (Kuiper et al., 1989; Lubahn et al., 1989). The promoters of the human (Tilley et al., 1990; Faber et al., 1991B; Mizokami et al., 1994), rat (Baarends et al., 1990) and mouse (Faber et al., 1991A) androgen receptors were characterized, and were found to be located approximately $1 \mathrm{~kb}$ upstream from the translation initiation codon in exon 1. The:e has only one androgen receptor gene been found, despite the fact that there are two ligands.

Using cDNA constructs encoding deletion mutants and their transient expression in $\operatorname{COS}$ cells, it was possible to identify individual domains in the androgen receptor molecule (Figure 1.1). Similar to all members of the steroid receptor superfamily, the human androgen receptor consists of a central DNA binding domain, a C-terminal ligand binding domain, and an $\mathrm{N}$-terminal domain which is important for transcriptional activity (Jenster et al., 1991; Simental et al., 1991). 


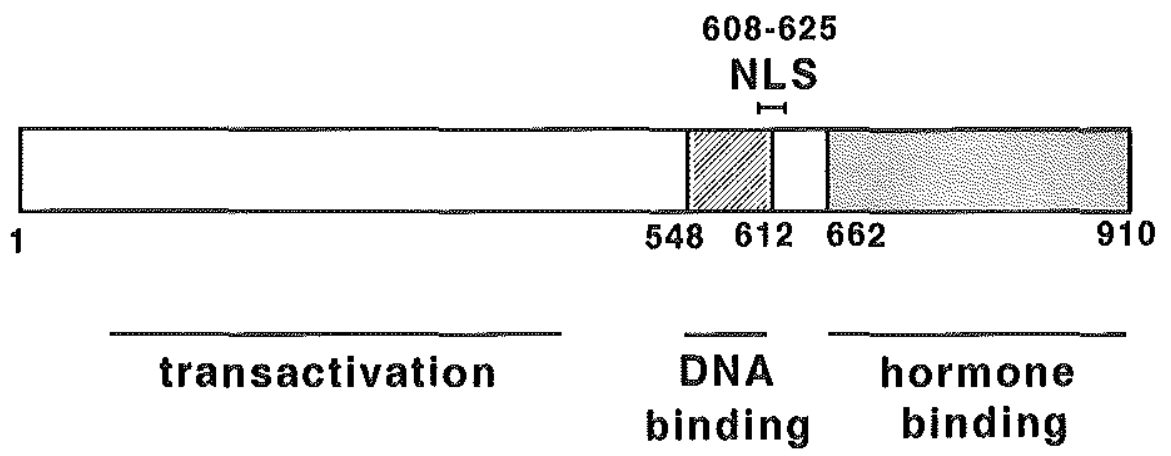

Figure 1.1. Structure of the human androgen receptor.

Indicated are the N-terminal trans-activation domain, the DNA binding domain, the nuclear localization signal (NLS), and the hormone binding domain. The DNA binding domain (amino acid residues 548 to 612) contains two zinc fingers and is $100 \%$ homologous to the DNA binding domain of the rat and mouse androgen receptors. The same accounts for the hormone binding domain (amino acid residues 662 to 910 ).

Apart from the glutamine and glycine amino acid repeats, another important characteristic of the androgen receptor $\mathrm{N}$-terminal domain is the relatively high content of acidic amino acid residues (Faber et al., 1989; Faber et al., 1991A). Acidic regions in transcription factors are directly involved in activation of transcription (Ptashne, 1988; Mitchell and Tjian, 1989; Latchman, 1990). The $\mathrm{N}$-terminal domain of the androgen receptor was indeed found to be essential for transcriptional activation by the androgen receptor, during transient expression experiments in COS and HeLa cells, with cotransfection of an androgen regulated reporter gene (Rundlett et al., 1990; Jenster et al., 1991; Simental et al., 1991; Palvimo et al., 1993). Deletion of a large part of this 
domain ( $\Delta 51-211)$ inactivated the androgen receptor trans-activation capacity (Jenster et al., 1991). The importance of the $\mathrm{N}$-terminal domain of the androgen receptor deduced from these transfection experiments, was confirmed in vivo in an individual with complete androgen insensitivity, who showed a large truncation of the N-terminal domain but no structural changes in the DNA- and hormone binding domains (Zoppi et al., 1993).

The ligand binding domain of the androgen receptor consists of approximately 250 amino acid residues, and binds the ligand in a hydrophobic pocket (Jenster et al., 1991). The integrity of the complete ligand binding domain is important for receptor activity. Deletions in the steroid binding domain as well as truncation of the last $12 \mathrm{C}$-terminal amino acid residues abolished hormone binding (Jenster et al., 1991). Point mutations in the androgen receptor ligand binding domain are a frequent cause of $\mathrm{X}$-linked androgen insensitivity (Brinkmann and Trapman, 1992; Ris-Stalpers et al., 1994).

One of the motifs which have evolved for protein-DNA interactions are autonomously folding zinc binding domains, which require zinc for folding and for DNA binding activity (Klug and Rhodes, 1987). A certain type of so-called zinc fingers has been described in the steroid nuclear receptor family. This motif binds two zinc atoms to form a single folded domain of 66 amino acids, with four cysteine residues acting as ligands for each zinc atom (Schwabe and Rhodes, 1991). The crystal structures of the glucocorticoid- and estrogen receptors zinc fingers bound to their specific DNA target sequences have been determined (Luisi et al., 1991; Schwabe et al., 1993). The structures are very similar to those of the estrogen receptor and glucocorticoid receptor zinc finger domains as determined by NMR-spectroscopy, and show that the receptor binds to DNA as a dimer (Schwabe et al., 1990; Härd et al., 1990). Sequence specific DNA interactions occur through an $\alpha$-helix, which lies in the major groove of the DNA. The most important amino acid residues in this regard are identical 
for the glucocorticoid and androgen receptors, and the androgen receptor therefore can be expected to interact in a similar way with target DNA (Härd and Gustafsson 1993, and references therein).

The androgen receptor undergoes homodimer formation in association with DNA binding (Wong et al., 1993; De Vos et al., 1994; Kallio et al., 1994). The dimerization domain is located within the DNA binding domain and the hinge region of the receptor (Wong et al., 1993). Mutational analysis of the mouse estrogen receptor ligand binding domain has identified a subregion near the $\mathrm{C}$ terminal end, involved in receptor dimerization (Fawell et al., 1990). Although this region is conserved in other receptors, the general importance of this region in steroid receptor dimerization remains to be confirmed for other receptors.

The cloning of the human androgen receptor cDNA, and the elucidation of the androgen receptor primary structure, have provided information to generate androgen receptor specific antibodies, using synthetic peptides as antigens in rabbits or mice (van Laar et al., 1989; Husmann et al., 1990; Shan et al., 1990; Zegers et al., 1991). In this way polyclonal and monoclonal antibodies were obtained against epitopes in the $\mathrm{N}$-terminal domain, the DNA binding domain, and the ligand binding domain of the androgen receptor (van Laar et al., 1989; Zegers et al., 1991; Veldscholte et al., 1992B). The androgen receptor antibodies appeared to be a powerful research tool. For example, they were used to investigate nuclear import of the androgen receptor after transient expression of deletion and substitution mutants in various cell lines (Jenster et al., 1991; Simental et al., 1991; Kemppainen et al., 1992; Jenster et al., 1993; Zhou et al., 1994B). Expression of the wild type androgen receptor in different cell lines revealed a cell line-specific subcellular distribution of the unliganded receptor between the nuclear and cytoplasmic compartments (Jenster et al., 1993). However, upon addition of hormone the androgen receptor was located 
exclusively in the nucleus, independent of the cell line used (Jenster et al., 1993). Mutagenesis studies revealed a bipartite nuclear targeting signal at amino acid residues 608-625 of the human androgen receptor (Figure 1.1), consisting of two clusters of basic amino acid residues (Jenster et al., 1993; Zhou et al., 1994B). Such a nuclear localization signal is present in many other nuclear proteins, including all steroid receptors (Dingwall and Laskey, 1991; Robbins et al., 1991). The human androgen receptor was also visualized immunohistochemically, using a mouse monoclonal antibody directed against a fragment of the $\mathrm{N}$-terminal domain, in various human tissues and in prostate cancer tissue (Ruizeveld de Winter et al., 1991; van der Kwast et al., 1991). In all tissues investigated, nuclear localization of the androgen receptor was predominant if not exclusive, irrespective of the presence or absence of hormone.

\subsection{Interaction of the androgen receptor with target genes}

When it was recognized that hormone-induced transformation of steroid receptors caused them to interact with chromatin, many attempts were made to identify the acceptor sites to which the transformed receptors become attached (Jensen, 1979; Spelsberg et al., 1987; Rejman et al., 1991).

With regard to the chemical composition of the androgen receptor acceptor sites, non-histone proteins and DNA have been implicated as the major components (Mulder and Brinkmann, 1985, and references therein). On the basis of the relative binding affinities for androgen receptors, evidence was obtained for at least two classes of acceptor sites in rat ventral prostate chromatin (Davies and Thomas, 1984; Davies et al., 1985). One class has a high affinity and low capacity for the androgen receptor and is functionally associated with transcriptionally active chromatin, whereas the other class has a lower affinity but higher capacity for the androgen receptor (Davies et al., 1985). Studies 
involving covalent cross-linking with formaldehyde of rat prostate androgen receptors bound to chromatin acceptor sites in situ, have supported the existence of two distinct classes of acceptor sites (Foekens et al., 1985; Rennie et al., 1987). These cross-linking experiments showed that only about $20 \%$ of the androgen receptor molecules are in a configuration allowing direct contact with acceptor DNA, whereas the remaining $80 \%$ is associated with acceptor proteins (Foekens et al., 1985). However, it is not certain whether these two fractions are indicative of acceptor sites associated with transcriptionally active and inactive regions of prostatic chromatin, respectively.

Studies with reconstituted systems using genomic DNA fragments have indicated preferential binding of purified androgen receptors to specific regions and nucleotide sequences of genes regulated by androgens. One such an androgenregulated gene encodes prostatein, also known as prostatic binding protein (PBP) or prostatic secretion protein, which is the major secretory protein of rat ventral prostate (Forsgren et al., 1979; Peeters et al., 1982; Viskochil et al., 1983). This protein consists of three different subunits: $\mathrm{C} 1, \mathrm{C} 2$ and $\mathrm{C} 3$, arranged as two heterodimers ( $\mathrm{C} 1 \mathrm{C} 3$ and $\mathrm{C} 2 \mathrm{C} 3$ ). The $\mathrm{C} 3$ subunit of rat prostatein can be encoded by two genes, but only one of these genes appears to be transcribed (Parker et al., 1983). It has been demonstrated that C3 mRNA is regulated acutely by androgens, and regulation appears to be at the levels of transcription and mRNA tumover (Peeters et al., 1980; Page and Parker, 1982). This regulation was thought to involve the interaction of the transformed androgen receptor with specific binding sites at or near the $\mathrm{C} 3$ gene transcription start site. Partially purified androgen receptor from rat prostate or prostatic adenocarcinoma bound to two DNA fragments from within the C3 subunit gene as shown in DNA cellulose competition assays (Perry et al., 1985; Rushmere et al., 1987; van Dijck et al., 1989). The specific sequences bound by the androgen 
receptor were not identified in these studies. However, both fragments, i.e. the $0.3 \mathrm{~kb}$ fragment 5 '-upstream of the transcription initiation site and the $0.5 \mathrm{~kb}$ fragment of the first intron, contained 15 bp imperfect palindromic sequences resembling a GRE (glucocorticoid responsive element).

DNA sequences responsible for regulation by steroid hormones have been found in inducible genes by gene transfer experiments (Yamamoto, 1985, and references therein). In these experiments, a chimaeric gene is constructed consisting of a putative regulatory DNA fragment cloned in front of a reporter gene and subsequently introduced into a heterologous steroid hormone responsive cell line. In this way, a 15 -mer consensus sequence for the glucocorticoid responsive element (GRE) and a 13-mer consensus sequence for the estrogen responsive element (ERE) were identified (Beato, 1989, and references therein). Subsequently, it was shown that the GRE is also able to mediate induction of a reporter gene by progesterone and testosterone (Strähle et al., 1987; Ham et al., 1988). Mutations within the GRE-like sequence in the $0.5 \mathrm{~kb}$ intron fragment of the $\mathrm{C} 3$ gene eliminated the response to androgens during transfer experiments in T47D cells, thus confirming that this sequence could function as an androgen responsive element (Claessens et al., 1989). The androgen responsive element in the first intron of the $\mathrm{C} 3$ gene was further investigated in transfection experiments, using CVI and COS cells after cotransfection of an androgen receptor expression vector (Tan et al., 1992).

Additional examples of androgen regulated genes are the genes encoding human prostate specific antigen (Riegman et al., 1991A; Wolf et al., 1992), mouse sex limited protein (Adler et al., 1992), rat ornithine decarboxylase (Crozat et al., 1992), rat S-adenosylmethionine (Maric et al., 1992), rat probasin protein (Rennie et al., 1993), rat cystatin-related glycoproteins (De Vos et al., 1993), mouse vas deferens aldo-keto reductase (Fabre et al., 1994), human and rat prostate specific acid phosphatase (Virkkunen et al., 1994), and the human 
glandular kallikrein-1 (hKLK2) protein (Riegman et al., 1991B; Murtha et al., 1993). Sequences, similar to the GRE were found in the promoter regions of all these genes, and from functional analysis a consensus ARE was defined as 5'GGA/TACAnnnTGTTCT, which is very similar to the consensus GRE 5'GGTACAnnnTGTTCT (Roche et al., 1992; Kallio et al., 1994). The recognition of a GRE-like sequence by the androgen receptor probably reflects the highly conserved $\mathrm{P}$ and $\mathrm{D}$ boxes in the DNA binding domains of the androgenand glucocorticoid receptors. The $\mathrm{P}$ box recognizes a specific half site DNA sequence, while the D box facilitates binding of two receptors to the GRE by protein-protein interactions leading to receptor dimerization (Umesono and Evans, 1989; Freedman, 1992). Intact human and rat androgen receptors, or fragments thereof containing the DNA binding domain, have been produced in E.Coli, insect cells, COS cells or by in vitro translation, and were used for analysis of the androgen receptor DNA binding properties in vitro (Young et al., 1990; De Vos et al., 1991; Tan et al., 1992; Yan-Bo Xie et al., 1992; Kuiper et al., 1993; Palvimo et al., 1993; De Vos et al., 1994; Kallio et al., 1994; Krempelhuber et al., 1994). In all studies, sequence specific binding of androgen receptor to GRE/ARE containing oligonucleotides was shown, and evidence was provided that the receptor binds as a homodimer to DNA (Kallio et al., 1994). Segments flanking the DNA binding domain were reported to influence the stability of receptor-DNA complexes (Palvimo et al., 1993; Kallio et al., 1994), indicating that protein-protein contacts involving the $\mathrm{N}$-terminal domain are stabilizing the dimeric receptors bound to DNA.

Although the presence of hormone was not needed for specific androgen receptor-DNA complex formation in vitro, the presence of androgens altered the mobility of receptor-DNA complexes during electrophoretic mobility shift analysis (Kaspar et al., 1993; Palvimo et al., 1993). This implies that binding of 
ligand induces a conformational change in the androgen receptor, at least when bound to DNA. Nevertheless, there seems to be a discrepancy between the in vitro situation where hormone is not essential for receptor-DNA complex formation, and the in vivo situation where hormone is essential. The general model for steroid hormone action involves binding of the hormone to the receptor followed by a conformational change, called transformation, which leads to binding to chromatin (Jensen et al., 1968). This model was confirmed by genomic footprinting studies in which the hormone responsive element of the hepatic tyrosine aminotransferase gene was shown to be occupied only after hormone administration (Becker et al., 1986). One possible explanation for this apparent discrepancy is that in vivo the steroid free receptor is associated with hsp90, which prevents the receptor from binding to chromatin (Groyer et al., 1987; Denis et al., 1988; Pratt, 1990; Smith and Toft, 1993). Upon binding of the hormone, hsp90 dissociates, leaving the DNA binding domain of the receptor free to bind to chromatin. Also the androgen receptor is associated with hsp90, both in intact cells and after recovery of the unliganded receptor in hypotonic cell lysates. Furthermore, androgens promote the temperature dependent dissociation of androgen receptors from hsp90 (Veldscholte et al., 1992A; Veldscholte et al., 1992B).

The DNA binding domain of the androgen receptor has a high degree of amino acid sequence similarity with progesterone and glucocorticoid receptors, and as a consequence the receptors recognize very similar hormone responsive elements. However, the ligands of these different receptors elicit biological responses that are ligand specific, suggesting that accessory factors interacting with regions outside the DNA binding domain are important determinants for steroid- and receptor-specific actions. The mouse sex limited protein gene (Slp) is a duplicated complement $\mathrm{C} 4$ gene, whose expression in several tissues is 
androgen dependent due to the influence of an inserted provirus (Stavenhagen and Robins, 1988; Adler et al., 1992). Within the 5' proviral long terminal repeat, which functions as a hormone-dependent enhancer, a GRE is present. However, the enhancer is activated by androgens and not by glucocorticoids or progestins (Adler et al., 1992). Potent androgen induction requires both the glucocorticoid responsive element and auxiliary elements also present within a 120 bp DNA fragment (Adler et al., 1992; Adler et al., 1993). Co-transfection assays with the glucocorticoid receptor revealed that the glucocorticoid receptor can bind to the responsive element, but is unable to trans-activate. The positive effect of the androgen receptor appears to require the $\mathrm{N}$-terminal domain of the androgen receptor. Thus, the exclusive transcriptional response to androgens derives from interactions between cell specific non-receptor factors and the androgen receptor. These interactions are determined by the context of the receptor binding site, rather than by the sequence of the binding site itself.

It is generally accepted that steroid receptors are trans-acting regulatory factors with an enhancer function on steroid target genes (Beato, 1989). As outlined above, also for the androgen receptor clear evidence is available for the interaction with nucleotide sequences upstream of steroid regulated genes, and subsequent receptor-mediated stimulation of transcription initiation. This does not exclude, however, a possible participation of chromatin structure and alterations of chromatin structure in the mechanism of action of androgens. Upon castration of rats, ventral prostate chromatin regions containing acceptor sites and androgen responsive genes, are withdrawn into a more compact structure, inaccessible to micrococcal nuclease (Davies and Rushmere, 1988). This trend is reversed in vivo by administration of andiogens (Davies et al, 1985). The androgen receptor is obviously able to alter chromatin structures into a transcriptionally more favourable form, and could act as a competence factor, 
enabling separate factors to act as enhancers on certain genes. Detailed evidence has been presented for a role of the glucocorticoid receptor in removal of promoter repression due to nucleosome positioning on the MMTV promoter. In this mechanism of action, there is no direct interaction between the receptor and other transcription factors (Truss et al., 1992; Eriksson and Wränge, 1993).

\subsection{Conclusions}

Androgenic steroids circulate in the blood and diffuse in and out of cells, but are retained in target cells by binding with an intranuclear binding protein, termed androgen receptor. The androgen receptor binds its specific steroid with high affinity, having an equilibrium dissociation constant $(\mathrm{Kd})$ in the range of $10^{-9}$. $10^{-10} \mathrm{M}$. The androgen receptor can be isolated from the cytosol of target cell extracts as a large non-transformed (i.e. non-DNA binding) $8 \mathrm{~S}$ oligomeric complex, which contains hsp90. Once bound by androgens, the androgen receptor undergoes a conformational change termed "transformation", which involves dissociation of heat-shock proteins from the $8 \mathrm{~S}$ complex. This transformation allows the androgen receptor to bind with high affinity to specific sites (acceptor sites) on the chromatin. The result of the binding to nuclear acceptor sites by the androgen receptor is the alteration of gene transcription (Figure 1.2). In which way the androgen receptor, once positioned on a hormone responsive element in the promoter of a target gene, precisely modulates transcriptional efficiency, is poorly understood. This probably requires functional interactions between receptor molecules as well as interactions with other essential transcription factors (Figure 1.2). 


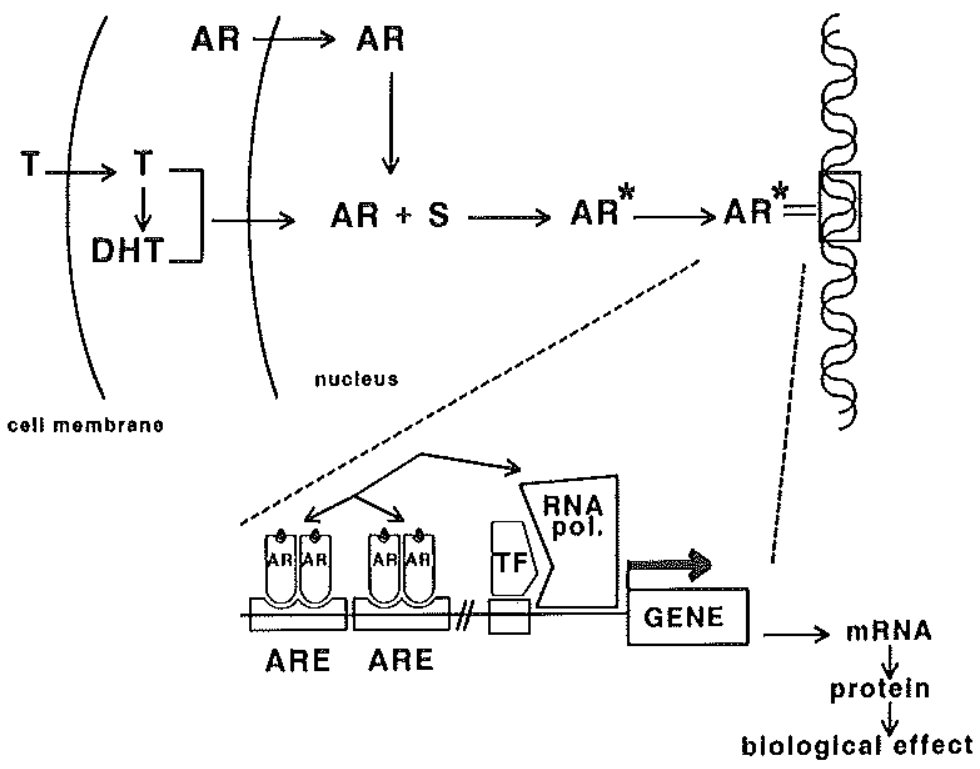

Figure 1.2. Schematic representation of the mechanism by which androgens regulate gene expression.

Testosterone ( $\mathrm{T}$ ) enters the cell and can be metabolized to $5 \alpha$-dihydrotestosterone (DHT). T or DHT $(=S)$ can bind to the androgen receptor (AR) which subsequently undergoes transformation. The transformed androgen receptor $\left(\mathrm{AR}^{*}\right)$ binds to androgen responsive elements (AREs) in front of androgen regulated genes and interacts with other transcription factors (TF), and RNA polymerase.

References : see end of Chapter 2. 


\section{CHAPTER 2}

STEROID HORMONE RECEPTOR PHOSPHORYLATION 


\subsection{Introduction}

Protein phosphorylation is generally acknowledged as an important way of acute regulation of protein function in eukaryotic cells. Thousands of proteins are expressed in a typical eukaryotic cell, of which about a third is thought to be a phosphoprotein. Two hundred protein kinases and some hundred protein phosphatases have been identified, and it is estimated that $3 \%$ of all eukaryotic genes may code for protein kinases and phosphatases (Hubbard and Cohen, 1993). Protein phosphorylation is often concerned with switching of a cellular activity from one state to another. It is the major mechanism by which cells respond to extracellular signals, and it is responsible for the timing of events which must occur at defined stages during the cell cycle, such as DNA synthesis and mitosis.

Among the phosphoproteins, the nuclear proteins are a special group (Meek and Street, 1992). These include transcription factors as CREB, Jun, Fos, NFxb, Myc and Myb; tumor suppressor proteins as $\mathrm{p} 53$, and the retinoblastoma susceptibility gene protein product (pRB), and viral proteins as the SV40 large tumor antigen. Each of these proteins can be phosphorylated at multiple sites, most often by different kinases. In some cases phosphorylation at a certain site occurs in response to different signals. For transcription factors three main mechanisms of regulation by phosphorylation can be identified (Hunter and Karin, 1992). First, the DNA binding affinity of transcription factors can be modulated negatively or positively by phosphorylation. Second, phosphorylation can affect the interaction of trans-activation domains of transcription factors with components of the transcription initiation complex. Third, phosphorylation can influence the shuttling of transcription factors between the nuclear and cytoplasmic compartments, thereby regulating indirectly the activity of transcription factors in the nucleus. These mechanisms ate by no means 
mutually exclusive, and (de)phosphorylation at different sites by different kinases or phosphatases can result in differential regulation of a single transcription factor by several mechanisms (Jackson, 1992). Most members of the nuclear receptor superfamily, including the glucocorticoid, estrogen, progesterone, androgen, 1,25-dihydroxyvitamin $\mathrm{D}_{3}$ and mineralocorticoid receptors are phosphoproteins. These receptors become rapidly extra phosphorylated upon binding of their respective ligands, suggesting that phosphorylation has an important role in the regulation of steroid receptor activity. The goal of this chapter is to describe the state of art of the rapidly advancing field of steroid receptor phosphorylation, and to indicate in which way phosphorylation might regulate steroid receptor activity.

\subsection{Indirect evidence for a role of steroid hormone receptor phosphorylation}

The first indications that steroid hormone receptor function might be regulated through phosphorylation processes came from studies, showing that cortisol binding by the glucocorticoid receptor in thymus cells varied with intracellular ATP levels (Munck and Brinck-Johnsen, 1968; Bell and Munck, 1973). Similarly, decrease of DHT binding in prostatic tissue homogenates after incubation of tissue slices with compounds causing loss of ATP (2,4-dinitrophenol, cyanide, or azide) and subsequent increase of DHT binding by incubation of the homogenates with ATP, suggested that an ATP requiring process was involved in androgen receptor function (Liao and Fang, 1969; Liao et al., 1975; Rossini and Liao, 1982). These, and several other studies, led to a model of receptor cycling, in which an inert (non-ligand binding) form of the receptor is produced from the transformed receptor in the nucleus. Subsequently, an ATP-dependent process restores the ability to bind steroid and the receptor 
is recycled to the nucleus after steroid binding (Rossini, 1984). Further indications for a possible role of phosphorylation in steroid hormone action came from studies involving phosphatases and phosphatase inhibitors. The loss in hormone binding capacity of glucocorticoid-, estrogen- and progesterone receptors that occurs on incubation of cytosolic extracts of target cells at 15$25^{\circ} \mathrm{C}$, was prevented by phosphatase inhibitors such as molybdate and fluoride (Nielsen et al., 1977A; Auricchio and Migliaccio, 1980; Grody et al., 1980). Loss of hormone binding capacity also occurred on treatment of the glucocorticoid receptor with purified alkaline phosphatase, and on treatment of mouse uterus estrogen receptor with a purified nuclear phosphatase (Nielsen et al., 1977B; Auricchio et al., 1985). The binding ability of the mouse uterus estrogen receptor after phosphatase treatment could be restored by incubation with ATP and a kinase preparation purified from uterus (Auricchio et al., 1985). Collectively, these studies indicated that the steroid binding capacity of receptors was lost either by dephosphorylation of receptors or of associated proteins and could be restored by rephosphorylation.

More evidence that steroid hormone receptors are phosphoproteins came from studies in which partially purified receptor preparations were incubated with purified kinases. In experiments with cAMP-dependent protein kinase, it was shown that the progesterone receptor from chicken oviduct can undergo phosphorylation in vitro (Weigel et al., 1981; Singh et al., 1986). Also, the purified glucocorticoid receptor from rat liver could be phosphorylated in vitro by incubation with cAMP-dependent protein kinase (Singh and Moudgil, 1985). Purified estrogen receptor from calf uterus was shown to be phosphorylated in vitro by an purified calcium/calmodulin dependent protein kinase on tyrosine residues (Auricchio et al., 1985). Androgen receptor from rat prostate was suggested to be phosphorylated by a cAMP-independent protein kinase, although 
in this study no direct evidence was provided that the phosphoprotein represented the androgen receptor (Goueli et al., 1984). Clearly, these studies, using partially purified receptor preparations, were limited by the difficulty of separating receptors from other proteins, including endogenous kinase and phosphatase activities.

In another series of experiments, target cells or target tissue slices were incubated with $\left[{ }^{32} \mathrm{P}\right]$-orthophosphate, and thereafter attempts were made to purify the respective steroid receptors. This purification involved "classical" methods as chromatography on DNA cellulose or phosphocellulose columns, and steroid affinity chromatography. In this way it was demonstrated that the glucocorticoid receptor (90-94 $\mathrm{kDa}$ ) becomes phosphorylated in rat liver slices and in intact mouse L cells (Housley and Pratt, 1983; Grandics et al., 1984; Singh and Moudgil, 1985). Also the progesterone receptor was shown to be phosphorylated after incubation of chicken oviduct minces with $\left[{ }^{32} \mathrm{P}\right]$-orthophosphate and purification via affinity chromatography (Dougherty et al.,1982). In most of these studies molybdate-stabilized receptor forms have been used. Subsequent studies have shown that this form of receptor is associated with a non-hormone binding $90 \mathrm{kDa}$ heat-shock protein (Joab et al., 1984). This protein was found to be phosphorylated in mouse fibroblasts (Housley et al., 1985). Therefore, a portion of the $90-94 \mathrm{kDa}{ }^{32} \mathrm{P}$-labelled proteins observed in these reports could in fact belong to the $90 \mathrm{kDa}$ non-hormone binding protein co-purifying with the glucocorticoid and progesterone receptors. Phosphorylation of the estrogen receptor $(65 \mathrm{kDa})$ on tyrosine residues was observed after incubation of rat uterine tissue with $\left[{ }^{32} \mathrm{P}\right]$-orthophosphate and purification of the estrogen receptor with steroid affinity chromatography (Migliaccio et al., 1986). Considerable progress in the studies on steroid receptor phosphorylation occurred at the time when specific polyclonal and monoclonal antibodies suitable to purify receptors 
from target cells or tissues became available.

\subsection{Basal and hormone dependent phosphorylation of steroid receptors}

When steroid target cells in culture or target tissue slices are incubated with $\left[{ }^{32} \mathrm{P}\right]$-orthophosphate, steroid hormone receptors can be shown to be phosphorylated after immunopurification and SDS-PAGE. The use of antibodies for the purification of receptors has the great advantage that rigorous washing steps (high salt and detergents) can be used, so that co-purification of contaminating phosphoproteins can be excluded. Furthermore, by immunopurification it is possible to compare the phosphorylation degree of steroid receptors in the absence or presence of ligand, which is impossible when "classical" purification strategies based on binding of tritiated ligands are employed. Steroid hormone receptors are already phosphoproteins in the absence of ligands, which will be designated basal phosphorylation. The progesterone receptor was shown to be phosphorylated in cytosolic extracts as well as in high salt nuclear extracts (transformed receptor) in rabbit uterine slices (Logeat et al., 1985). In later studies progesterone receptor phosphorylation was also described in human breast tumor cells (T47D cells), chicken oviduct slices, and in primary cultures of chicken oviduct cells (Garcia et al., 1986A; Denner et al., 1987; Wei et al., 1987; Sheridan et al., 1988; Sullivan et al., 1988A). Phosphorylation of the glucocorticoid receptor was described in WEHI-7 thymoma cells and mouse Lcells (Mendel et al., 1987; Tienrungroj et al., 1987). Estrogen receptor phosphorylation has been described in mouse uterus, calf uterus, and in the MCF7 human breast cancer cell line (Lahooti et al., 1990; Washburn et al., 1991; Denton et al., 1992), and human androgen receptor phosphorylation was found in human lymph node carcinoma of the prostate (LNCaP) cells (Van Laar et al., 1990). The effects of vitamin D are mediated by the receptor that binds 
the active metabolite 1,25-dihydroxyvitamin $\mathrm{D}_{3}$. Phosphorylation of this receptor was observed in organ culture studies of embryonic chicken duodenum (Brown and DeLuca, 1990). In contrast, no basal phosphorylation of the 1,25-dihydroxyvitamin $D_{3}$ receptor was observed in mouse fibroblasts (Pike and Sleator, 1985). No data are available on phosphorylation of the mineralocorticoid receptor in target cells or tissue, only the mineralocorticoid receptor overexpressed in Sf9 insect cells was reported to be phosphorylated (Alnemri et al., 1991).

Steroid receptors become extra phosphorylated on incubation of target cells or tissues in culture with their respective ligands. This extra phosphorylation is a rapid process (within $30 \mathrm{~min}$ ) and is associated with receptor transformation to the tight nuclear binding form in several systems. The rapid increase in receptor phosphorylation upon ligand binding is often used as an argument to stress the importance of steroid receptor phosphorylation (see Figure 2.1). Hormone stimulated extra phosphorylation has been reported for the glucocorticoid receptor in WEHI-7 thymoma cells, 3T3 fibroblasts and in hepatoma cells (Hoeck et al., 1989; Orti et al., 1989; Hoeck and Groner, 1990). The unliganded glucocorticoid receptor was found to exist as a heteromeric complex containing one steroid binding unit and two hsp90 monomers, and probably also other heatshock proteins. Upon hormone binding at $37^{\circ} \mathrm{C}$ these heteromeric complexes dissociate, followed by receptor transformation to the DNA binding form. Kinetic studies in WEHI-7 cells revealed that the primary substrate for hormone stimulated extra phosphorylation was the transformed receptor (Orti et al., 1993). Also the non-transformed receptor became extra phosphorylated, albeit at a lower rate (Orti et al., 1989). This extra phosphorylation was induced by glucocorticoid agonists, but not by the antagonist RU486 (Hoeck et al., 1989), which suggested a functional role for glucocorticoid receptor phosphorylation. 


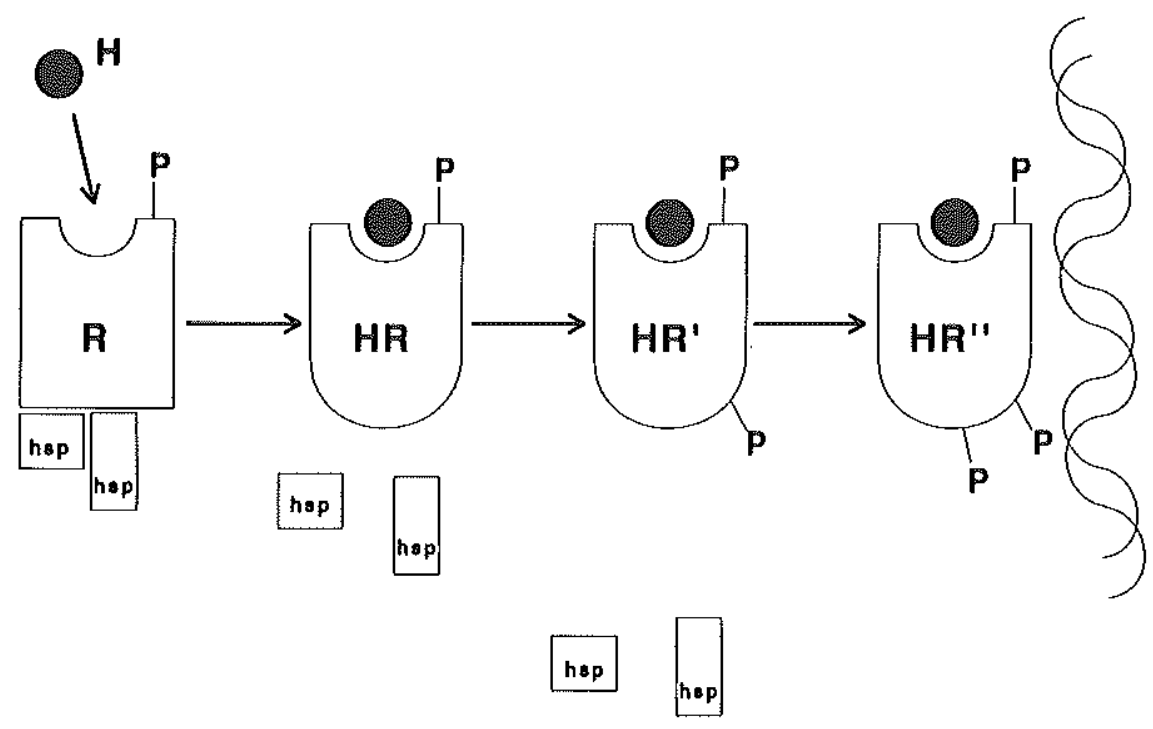

Figure 2.1. Basal and hormone dependent steroid hormone receptor phosphorylation.

The unliganded receptor $(R)$ is already phosphorylated. Upon ligand binding the receptor (HR) undergoes a conformational change, and the heat-shock proteins dissociate. The transformed (DNA bound) steroid receptor (HR") and the nontransformed steroid receptor (HR') are extra phosphorylated.

Addition of progesterone to T47D cells or to chicken oviduct slices caused a rapid extra phosphorylation of the progesterone receptor (Wei et al., 1987; Sheridan et al., 1988; Sullivan et al., 1988B; Nakao et al., 1989). In contrast to the glucocorticoid receptor, RU486 did promote human progesterone receptor transformation and phosphorylation in T47D cells (Sheridan et al., 1989A), but 
had no effect on the phosphorylation degree of the chicken oviduct progesterone receptor (Nakao et al., 1989). RU486 does not bind to chicken and hamster progesterone receptors, but does bind to the human progesterone receptor. A single amino acid species variation in the ligand binding domain was shown to be responsible for this differential antagonistic effect of RU486 (Groyer et al., 1985; Eliezer et al., 1987; Gronemeyer et al., 1992). A two-fold increase in androgen receptor phosphorylation in $\mathrm{LNCaP}$ cells was measured after incubation with R1881 (Van Laar et al., 1991). In transiently transfected COS-7 cells, it was found that the androgen receptor protein degraded rapidly $\left(t_{1 / 2}=1 \mathrm{~h}\right)$, except in the presence of androgen $\left(t_{1 / 2}=6 \mathrm{~h}\right)$, which accounted for an apparent 2-4 fold androgen-induced increase in androgen receptor phosphorylation (Kemppainen et al., 1992). Estrogen treatment of mouse uterine slices during metabolic labelling with $\left[{ }^{32} \mathrm{P}\right]$-orthophosphate caused extra phosphorylation of estrogen receptors (Washburn et al., 1991). In MCF-7 cells extra phosphorylation of the estrogen receptor after estradiol treatment was also found (Denton et al., 1992). Phosphorylation of the 1,25-dihydroxyvitamin $\mathrm{D}_{3}$ receptor was strongly induced after incubation of mouse fibroblast and embryonal chicken duodenum organ cultures with 1,25-dihydroxyvitamin $\mathrm{D}_{3}$ (Pike and Sleator, 1985; Brown and DeLuca, 1990). The stimulation factors reported ranged from 2 to 7 , often for one type of steroid hormone receptor in comparable systems. This variation might be due to differences in experimental conditions.

Post-translational modifications, including phosphorylation, of proteins can be detected by resolving isoforms of different apparent molecular masses during SDS-PAGE. This is an alternative method to study steroid receptor phosphorylation, which has been used extensively. The photoaffinity-labelled progesterone receptor (using the synthetic progestin ${ }^{3} \mathrm{H}-\mathrm{R} 5020$ ) gave a doublet 
of the untransformed protein with molecular masses of 117 and $120 \mathrm{kDa}$ (Horwitz et al., 1985). During the first $30 \mathrm{~min}$ of incubation with R5020, the progesterone receptor protein shifted entirely to the heavier form (120 kDa), most likely caused by a hormone-dependent covalent modification. In later studies it was shown that these isoforms of the progesterone receptor were caused by differential phosphorylation (Sheridan et al., 1989B). The mouse uterus estrogen receptor also appears as a doublet after SDS-PAGE, of which the higher molecular mass form is being induced by estrogens (Golding and Korach, 1988). Microheterogeneity after SDS-PAGE was detected also for the human glucocorticoid- and androgen receptors (Northrop et al., 1985; Van Laar et al., 1990). In rat osteosarcoma cells and mouse fibroblasts, treatment with 1,25-dihydroxyvitamin $D_{3}$ elicited a decrease in mobility of the 1,25-dihydroxyvitamin $\mathrm{D}_{3}$ receptor on SDS-PAGE (Pike and Sleator, 1985; Jurutka, 1993A).

\subsection{Location of phosphorylation sites in steroid hormone receptor proteins}

The majority of the glucocorticoid receptor phosphorylation sites could be located in the $\mathrm{N}$-terminal trans-activation domain using chemical cleavage with hydroxylamine and cyanogenbromide or proteolytic digestion with trypsin and chymotrypsin (Dalman et al., 1988; Smith et al., 1989; Hoeck and Groner, 1990; Hutchison et al., 1993). There is some debate on additional phosphorylation of the DNA- or steroid binding domains of the glucocorticoid receptor (Hutchison et al., 1993). In rat hepatoma cells, in mouse L cells, and in Chinese hamster ovary cells, the glucocorticoid receptor becomes also phosphorylated in the DNA binding domain, but not in the steroid binding domain (Dalman et al., 1988; Hoeck and Groner; 1990; Hutchison et al., 1993). In contrast, in AtT-20 mouse pituitary tumor cells the glucocorticoid receptor was found to be nonphosphorylated in the DNA binding domain (Van der Weyden Benjamin et al., 
1990). Only in WEHI-7 mouse thymoma cells the glucocorticoid receptor was, apart from the $\mathrm{N}$-terminal domain, also phosphorylated in the steroid binding domain, but not in the DNA binding domain (Smith et al., 1989). In a later study by the same laboratory it was found that a highly purified tryptic fragment containing the steroid binding domain is not phosphorylated, indicating that the earlier result might have been due to a contaminant (Bodwell et al., 1991). Progesterone receptors from chicken oviduct and from T47D cells are phosphorylated in the N-terminal domain (Sullivan et al., 1988B; Sheridan et al., 1989A). Also the rabbit progesterone receptor was shown to be predominantly phosphorylated in the N-terminal domain after transfection in COS cells (Chauchereau et al, 1991). The 1,25-dihydroxyvitamin $\mathrm{D}_{3}$ receptor was found to be phosphorylated in a fragment spanning the hinge region and a large part of the ligand binding domain (Brown and DeLuca, 1991). In another study only phosphorylation in the hormone binding domain was reported (Jones et al., 1991). In conclusion, most steroid receptors that have been investigated are phosphorylated at least in the $\mathrm{N}$-terminal trans-activation domain.

\subsection{Identification of phosphorylation sites}

Phosphoamino acid analysis has revealed that the glucocorticoid, progesterone-, and 1,25-dihydroxyvitamin $\mathrm{D}_{3}$ receptors are phosphorylated on serine residues (Dalman et al., 1988; Sheridan et al., 1988; Smith et al., 1989; Hoeck and Groner, 1990; Brown and DeLuca, 1991). For the glucocorticoid receptor, minor phosphorylation on threonine residues was also reported (Hoeck and Groner, 1990). Results on phosphoamino acid analysis of estrogen receptors were confusing. While Auricchio and co-workers showed that the estrogen receptor was only phosphorylated on tyrosine residues, other investigators reported specific phosphorylation on serine residues (Auricchio, 1989; Washburn et al., 
1991; Denton et al., 1992; Lahooti et al., 1994; LeGoff et al., 1994). The reason for this discrepancy is at present unknown.

By phosphopeptide mapping and sequencing of tryptic peptides, seven phosphorylated sites have been identified in the mouse glucocorticoid receptor (Bodwell et al., 1991). These sites are identical in CHO cells in which the glucocorticoid receptor was overexpressed, and in mouse thymoma cells (WEHI-7). All sites are on serine residues, except one site on a threonine residue, and are located in the N-terminal domain (Ser 122, 150, 212, 220, 234, 315 and Thr 159). Three serine residues $(212,220$ and 234$)$ are in a region which is essential for transcriptional activity of the mouse glucocorticoid receptor, and are present in the core trans-activation domain of the human glucocorticoid receptor (Danielsen et al., 1987; Dahlman-Wright et al., 1994). Data on the influence of glucocorticoids on the phosphorylation state of these sites are not yet available. Four phosphorylated sites in the chicken progesterone receptor have been identified (Denner et al,, 1990A; Poletti and Weigel, 1993). There are four SerPro motifs in the chicken progesterone receptor, which are all phosphorylated. Two sites (Ser 211 and Ser 260) are substantially phosphorylated in the absence of ligand, with a small increase in the presence of ligand, while phosphorylation of two other sites (Ser 367 and Ser 530) was essentially ligand-inducible. Upon expression of chicken progesterone receptor in the yeast Saccharomyces cerevisiae the receptor was correctly phosphorylated on all four Ser-Pro motifs (Poletti et al., 1993). The effects of ligand on the phosphorylation degree of the four sites were consistent with the authentic chicken progesterone receptor, showing that the yeast system is applicable to the study of the role of phosphorylation in progesterone receptor function. The human 1,25-dihydroxyvitamin $\mathrm{D}_{3}$ receptor transiently expressed in COS-1 cells was phosphorylated on serine residues (Hilliard et al., 1994). In order to obtain sufficient quantities for 
microsequencing of phosphopeptides, ${ }^{32} \mathrm{P}$-labelled 1,25-dihydroxyvitamin $\mathrm{D}_{3}$ receptor from COS cells was mixed with purified 1,25-dihydroxyvitamin $D_{3}$ receptor expressed in Saccharomyces cerevisiae. Sequencing of phosphopeptides obtained by digestion of receptor with various proteases, revealed phosphorylation at serine residue 208, within a consensus site for casein kinase II (Hilliard et al., 1994). Phosphorylation at this site was clearly stimulated (approx. 8 fold) by treatment of COS cells with 1,25-dihydroxyvitamin $D_{3}$.

Another approach for the identification of phosphorylation sites, is site-directed mutagenesis of consensus phosphorylation sites for various kinases, and subsequent transient expression of mutant proteins in COS cells or comparable systems. This strategy however is time-consuming and creates an additional problem, in that the abolition of a phosphorylation site by a point mutation might cause a conformational change. Furthermore, mutagenesis of a consensus phosphorylation site might promote phosphorylation at an alternative site, as has been shown for the human 1,25-dihydroxyvitamin $D_{3}$ receptor (Hilliard et al., 1994). Comparison of tryptic phosphopeptide maps of wild type and mutant human estrogen receptors expressed in COS cells, revealed phosphorylation at serine residues 104 and/or 106, and residue 118 (Ali et al., 1993; Le Goff et al., 1994). All three serine residues are part of a serine-proline motif, the preferred substrate of proline-directed protein kinases (Vulliet et al., 1989). By similar strategies the human 1,25-dihydroxyvitamin $\mathrm{D}_{3}$ receptor has been shown to be phosphorylated at serine residue 51 (protein kinase $\mathrm{C}$ site) within the DNA binding domain and at serine residue 208 (casein kinase II site) within the ligand binding domain (Hsieh et al., 1991; Jurutka et al., 1993B). 


\subsection{Protein kinases involved in steroid hormone receptor phosphorylation}

Several protein kinases have been reported to co-purify with the progesterone receptor. Co-purification of casein kinase-like protein kinases and magnesium dependent kinases with the rabbit and chicken progesterone receptors has been described. None of these kinases, however, showed hormone-stimulated phosphorylation of the progesterone receptor in vitro. The physiological significance of these findings is uncertain (Garcia et al., 1986B; Logeat et al., 1987). The chicken progesterone receptor is phosphorylated at all four Ser-Pro motifs in vivo (Denner et al., 1990A, Poletti and Weigel, 1993). The Ser/Thr-Pro motif is a portion of the consensus sequence for the cdc2 (cell division cycle) protein kinases and the mitogen-activated protein kinases, and these are therefore candidate kinases to phosphorylate the receptor (Vulliet et al., 1989; Mukhopadhyay et al., 1992). Chicken progesterone receptor is also phosphorylated by a DNA dependent protein kinase, during in vitro progesterone dependent transcription assays using $\mathrm{HeLa}$ cell nuclear extracts. This phosphorylation was strictly dependent on the presence of double-stranded DNA (Bagchi et al., 1992; Weigel et al., 1992). Further analysis of receptors isolated from chicken oviduct nuclear extracts will be necessary to determine whether this phosphorylation also occurs in vivo. The DNA dependent kinase that is involved also phosphorylates the transcription factor $\mathrm{Spl}$, and is a heterodimer composed of a catalytic subunit and a DNA binding subunit (Jackson et al,, 1993). The latter probably directs the kinase to DNA and can be regarded as a "targeting subunit", making possible efficient phosphorylation of DNA-bound substrates (Hubbard and Cohen, 1993). The DNA dependency of progesterone receptor phosphorylation in vitro was confirmed during in vivo experiments (Takimoto et al,, 1992). Analysis of mutant and wild type progesterone receptors expressed in COS -1 cells suggested that hormone-induced phosphorylation can 
be subdivided into two stages. The first stage is DNA independent, for which a receptor mutant lacking DNA binding activity is a substrate; the second stage is DNA dependent, for which the same receptor mutant is not a substrate. The synthetic antiprogestin ZK98299 binds progesterone receptors but prevents their interaction with DNA. Compared with progestin agonists, this antagonist reduced phosphorylation of progesterone receptors in T47D cells to $60 \%$ (Takimoto et al, 1992). These results indicate that the hormone-induced phosphorylation of the progesterone receptor involves DNA binding independent as well as DNA binding dependent steps (Takimoto et al., 1992; Takimoto and Horwitz, 1993).

Cell-free phosphorylation of the calf uterine estrogen receptor has been found to occur on tyrosine residues (Auricchio, 1989). A nuclear phosphatase from calf uterus inactivated hormone binding, and the resulting dephosphorylated receptor form could be converted back to an estrogen binding form by a cytosolic calcium/calmodulin dependent protein tyrosine kinase activity (Aurrichio, 1989). This kinase activity has been purified to homogeneity (Castoria et al., 1993). The uterus protein tyrosine kinase is a $67 \mathrm{kDa}$ protein on SDS-PAGE and binds calmodulin in a $\mathrm{Ca}^{2+}$ dependent manner. The kinase phosphorylates in vitro the phosphatase-treated calf uterus estrogen receptor on tyrosine, and thereby activates hormone binding. By site-directed mutagenesis of tyrosine residues, tyrosine residue 537 was identified as the phosphorylated residue. The mutant (Tyr 537 --> Phe) is neither phosphorylated nor activated with regard to estrogen binding by the kinase (Castoria et al., 1993). Remarkably, the kinase is dependent for its activity on the presence of purified calf uterus estrogen receptor. Whether the kinase becomes activated either by estrogen or by the estrogen receptor complex, or by an unknown compound in the purified receptor preparation, is presently unknown. Furthermore, it has not yet been shown that the estrogen receptor in calf uterus in vivo is also phosphorylated on tyrosine 
residue 537, and that this phosphorylation is essential for hormone binding capacity. The purified porcine uterus estrogen receptor was shown to be nonphosphorylated in the ligand binding domain (Bökenkamp et al., 1994). In chicken oviduct cytosol, the estrogen receptor exists in three forms: two forms which bind estrogen with low and high affinity respectively, and one form which does not bind estrogens at all (Raymoure et al., 1986). Conversion of the nonbinding form to the low affinity binding form in vitro requires $\mathrm{Mg}^{2+}$ and ATP (Raymoure et al., 1986). This conversion is mediated by a $40 \mathrm{kDa}$ activation factor that is associated with protein kinase as well as protein phosphatase activity (Dayani et al., 1990; McNaught et al., 1990). The amino acid(s) that are phosphorylated or dephosphorylated by this activation factor are presently unknown. The human estrogen receptor is phosphorylated on three Ser-Pro motifs, which is the preferred motif in substrates of the proline directed protein kinases including cdc2 kinase and the mitogen activated kinases (Le Goff et al., 1994). For the glucocorticoid receptor, proline directed protein kinases are also predominant, since four out of seven identified phosphorylation sites are in proline directed protein kinases consensus sequences (Bodwell et al., 1991). Since the proline directed protein kinases also phosphorylate the progesterone receptor (Denner et al., 1990), it might be concluded that this protein kinase is the principal protein kinase involved in steroid hormone receptor phosphorylation.

\subsection{Steroid hormone receptor phosphorylation and receptor function}

There is increasing evidence that gene expression is regulated by phosphorylation of transcription factors (Hunter and Karin, 1992; Jackson, 1992). Since steroid receptors are ligand-dependent transcription factors and also exist as phosphoproteins, several studies have been performed to uncover the 
physiological role(s) for receptor phosphorylation in steroid hormone action. The following receptor functions or activities linked to phosphorylation have been suggested: receptor association with heat shock proteins, activation of hormone binding capacity, nuclear import, subnuclear location, nucleocytoplasmic shuttling, modulation of binding to hormone responsive elements, receptor dimerization, and interactions with general transcription factors (Kuiper and Brinkmann, 1994).

The goal of this section is to describe the evidence available for the involvement of phosphorylation in some of these receptor functions.

\subsubsection{Role of phosphorylation in estrogen receptor mediated trans- activation}

In contrast to the results of Auricchio et al., there have been several reports showing estrogen receptor phosphorylation on serine residues (Auricchio, 1989; paragraph 2.5 and references therein). The liganded and unliganded estrogen receptor in MCF-7 breast carcinoma cells and calf uterus is phosphorylated on serine residues, and it was shown that treatment with acid phosphatase caused loss of affinity of the estrogen receptor for specific DNA sequences in vitro (Denton et al., 1992). Exposure of rat uterine cells in primary culture to estrogen, insulin-like growth factor I (IGF-I), or agents which alter intracellular cAMP levels, such as cholera toxin plus isobutylmethylxanthine (IBMX) and $8 \mathrm{Br}-\mathrm{cAMP}$, resulted in the upregulation of cellular levels of the progesterone receptor (Aronica and Katzenellenbogen, 1991). The progesterone receptor gene is a well known estrogen target gene. These effects were believed to be mediated through the estrogen receptor and phosphorylation pathways. It was indeed shown that in rat uterine cells transcription from a plasmid DNA containing two tandem estrogen responsive elements linked to a reporter gene, 
could be stimulated by estrogen and also by $8 \mathrm{Br}$-cAMP, cholera toxin plus IBMX, or IGF-I (Aronica and Katzenellenbogen, 1993). The level of estrogen receptor phosphorylation in uterine cells could be increased 3 to 5 fold upon exposure to one of the following: estrogen, cholera toxin plus IBMX, 8Br-cAMP or IGF-I (Aronica and Katzenellenbogen, 1993). However, the fact that an antiestrogen (ICI 164384) evoked a similar increase in estrogen receptor phosphorylation, without a concomitant increase in estrogen receptor mediated transcription activation, indicated that an increase in overall phosphorylation does not necessarily result in increased transcriptional activity (Aronica and Katzenellenbogen, 1993). Trans-activation by the estrogen receptor, therefore, might depend upon phosphorylation or dephosphorylation of a specific site or sites, the modulation of which might not be detected in overall phosphorylation. The location of the estrogen receptor phosphorylation sites in the $\mathrm{N}$-terminal transcription activation domain also suggested that phosphorylation might play a role in receptor trans-activation (Ali et al., 1993; Le Goff et al., 1994). Indeed, mutation of the three phosphorylated serine residues (residue 104, 106 and 118) caused a significant reduction (by 40\%) in trans-activation activity in response to estrogens (Ali et al., 1993; Le Goff et al., 1994), but did not affect the DNA binding properties and nuclear import of the receptor. The sites phosphorylated in response to incubation with cholera toxin plus IBMX or $8 \mathrm{Br}-\mathrm{cAMP}$, remain to be identified (Le Goff et al., 1994). In the neuroblastoma cell line SK-ER3 it was also shown that IGF-I, in the absence of estrogen, could increase the activity of an estrogen responsive promoter (Ma et al., 1994). Phosphorylation of the estrogen receptor was not investigated in these cells. It is clear from these studies on estrogen receptors that site-specific phosphorylation affects transcriptional activation, although overall phosphorylation is not a parameter by which the differential transcriptional activity of estrogens versus anti-estrogens can be distinguished. 


\subsubsection{Role of phosphorylation in progesterone receptor mediated trans- activation}

Studies on the phosphorylation of the progesterone receptor in T47D cells suggested that phosphorylation influences the ability of receptors to regulate gene transcription (Sheridan et al., 1988; Sheridan et al., 1989A). In the chicken progesterone receptor two hormone-induced phosphorylation sites (Ser 367 and Ser 530) have been identified (Denner et al., 1990A; Poletti and Weigel, 1993). Interestingly, each hormone dependent site is located in a separate area of the receptor, flanking the DNA binding domain and involved in trans-activation (Dobson et al., 1989). Substitution of serine residue 530 by an alanine residue in the chicken progesterone receptor resulted in a strong reduction in transcriptional activity, but only at low hormone concentrations (Bai et al., 1994). Effects of substitution of serine 367 alone or in combination with serine 530 were not studied. Mutation of serine residue 677 in the human progesterone receptor (homologous to serine residue 530 in the chicken receptor) reduced the trans-activation function by 30 to $50 \%$, on a simple but not on a complex promoter in COS cells and in HeLa cells (Takimoto et al., 1991). It is important to note that extra phosphorylation of the progesterone receptor is not always correlated with increased transcriptional activity, because the antagonist RU486 provoked extra phosphorylation of the human progesterone receptor, while blocking trans-activation (Chaucherau et al., 1991). The site(s) phosphorylated in response to RU486 treatment have not been identified yet.

Analysis of human progesterone receptor phosphorylation in HeLa cell nuclear extracts during in vitro transcription assays, showed that phosphorylation increased in parallel with progesterone-induced enhancement of RNA synthesis from a promoter containing a progesterone responsive element (Bagchi et al,, 1992). These data are correlative, because the presence of kinases in the 
transcription extract made it impossible to study the trans-activating properties of the progesterone receptor when it had not undergone phosphorylation. However, it is interesting to note that progesterone receptor phosphorylation was at least in part dependent on the presence of progesterone (Bagchi et al., 1992). Treatment of CV-1 cells transiently expressing chicken progesterone receptor, with $8 \mathrm{Br}-\mathrm{cAMP}$ or an inhibitor (okadaic acid) of protein phosphatases 1 and $2 \mathrm{~A}$, stimulated chicken progesterone receptor-mediated induction of transcription from a cotransfected reporter gene construct in the absence of progesterone (Denner et al., 1990B; Zhang et al., 1994). The ability to bypass hormonal activation of receptors with agents that modify cellular kinase or phosphatase activities, provided evidence that phosphorylation processes are involved in regulation of the transcriptional activity of progesterone receptors. In contrast, $8 \mathrm{Br}-\mathrm{cAMP}$ or okadaic acid did not stimulate target gene expression in the absence of progesterone in a T47D-derived cloned cell line, containing a stable transfected MMTV reporter gene construct (Beck et al., 1992). Either compound augmented human progesterone receptor-mediated target gene transcription by 3 to 4 fold when added together with progesterone (Beck et al., 1992). The reason for the differential effects of treatment of cells with 8Br-cAMP and okadaic acid on progesterone receptor-mediated transcription of human- and chicken progesterone receptors, are unknown. Both modulators had no effect on the extent of human progesterone receptor phosphorylation in T47D cells (Beck et al., 1992), while possible effects of modulators on chicken progesterone receptor phosphorylation in CV-1 cells were not investigated (Denner et al., 1990B). The chicken and calf progesterone receptors are substrates in vitro for cAMP-dependent protein kinase (Hurd et al., 1989; Denner et al., 1990A; Nakao et al., 1992). 


\subsubsection{Role of phosphorylation in glucocorticoid receptor mediated trans- activation}

The mouse glucocorticoid receptor is phosphorylated in the N-terminal domain at seven sites (serine residue 122, 150,212, 220, 234, 315, and threonine residue 159), in WEHI-7 mouse thymoma cells and in CHO cells (Bodwell et al., 1991). Three serines $(212,220$ and 234) are in a region which is essential for transcriptional activation, and are also present at homologous positions in the core trans-activation domain of the human glucocorticoid receptor (Danielsen et al., 1987; Dahlman-Wright et al., 1994). Substitution of serine residues by either alanine or aspartic acid residues did not influence receptor transactivation. Only glucocorticoid receptors with five different serine phosphorylation sites substituted by alanine residues exhibited an approximately $20 \%$ decrease in trans-activation capacity (Mason and Housley, 1993). From these studies, it was concluded that phosphorylation of the glucocorticoid receptor at the identified sites is not a major determinant in glucocorticoid receptor transcriptional activity from the MMTV promotor in COS cells. The possibility that the large overexpression of the glucocorticoid receptor in COS cells compensates for reduced trans-activation capacity of the mutant could be excluded, since expression in E 8.2 cells (a GR negative variant of $L$ fibroblasts) to a much lower level gave similar results (Mason and Housley, 1993).

In another study, the effects of okadaic acid, a protein phosphatase inhibitor, on trans-activation by the rat glucocorticoid receptor after transient expression in COS and CV-1 cells was investigated. In the absence of hormone, the glucocorticoid receptor was capable of enhancing transcription from the cotransfected MMTV-CAT reporter plasmid in response to okadaic acid treatment' (Somers and DeFranco, 1992). Synergistic enhancement resulted from combined dexamethasone and okadaic acid treatment. By analysis of chromatin structure 
it was shown previously that unliganded glucocorticoid receptors do not bind to glucocorticoid responsive elements in vivo (Becker et al., 1986). It is not known if trans-activation from glucocorticoid responsive elements by unliganded glucocorticoid receptors in okadaic acid treated COS and CV-1 cells is associated with the same alterations in chromatin structure as in vivo. The effects of okadaic acid on transcriptional enhancement did not correlate with major changes in glucocorticoid receptor phosphorylation, as was shown by two dimensional tryptic peptide mapping of ${ }^{32} \mathrm{P}$-labelled receptors (Somers and DeFranco, 1992). Thus, changes in phosphorylation of unknown component(s) of the glucocorticoid receptor signal transduction pathway, and not the receptor itself, may influence its transcriptional enhancement activity. Expression vectors for the glucocorticoid receptor and a hormone-responsive reporter (MMTV) were stably introduced in T47D breast tumor cells (Moyer et al., 1993). In these cells the dexamethasone response could be enhanced 2 to 10 fold by activators of protein kinase $\mathrm{A}$, protein kinase $\mathrm{C}$, and inhibitors of phosphatases (okadaic acid). Okadaic acid alone had no effect in these cells, in contrast to the previous study employing transient transfection in COS or CV-1 cells (Somers and De Franco, 1992). Treatment of the T47D cells with protein kinase activators or phosphatase inhibitors had no effect on either cellular receptor content or dexamethasone binding. Also, treatment of cells with protein kinase activators or phosphatase inhibitors alone or in combination with dexamethasone did not change the phosphorylation pattern of the glucocorticoid receptor compared to the pattern before or after dexamethasone treatment, respectively (Moyer et al., 1993). So, again no link could be made between stimulation of glucocorticoid receptor-mediated transcription and phosphorylation of the glucocorticoid receptor. 


\subsubsection{Role of phosphorylation in subcellular location of the glucocorticoid receptor}

In most studies it is shown that unoccupied glucocorticoid receptor proteins reside predominantly within the cytoplasmic compartment, and after ligand binding a rapid and efficient translocation of receptors to the nucleus occurs (Wikström et al., 1987). For rat hepatoma cells it was shown, however, that the glucocorticoid receptor is always in the nucleus (Brink et al., 1992). The nuclear glucocorticoid receptor is not indefinitely confined to the nuclear compartment after hormone treatment, but undergoes a recycling process involving the cytoplasm (Raaka and Samuels, 1983). When rat fibroblasts are treated with dexamethasone in the presence or absence of okadaic acid, the glucocorticoid receptor becomes extra phosphorylated and is translocated to the nucleus. When hormone is withdrawn the glucocorticoid receptor becomes cytoplasmic again. In cells continuously exposed to okadaic acid, however, the glucocorticoid receptor cannot re-enter the nucleus in the presence of dexamethasone and is trapped in the cytoplasmic compartment (DeFranco et al., 1991). It was postulated that okadaic acid blocks a dephosphorylation event that occurs either when the glucocorticoid receptor is exported from the nucleus or during the reassembly of a heteromeric complex with heat-shock proteins in the cytoplasm. These receptors, therefore, retain the extra phosphorylated state and are now trapped in the cytoplasmic compartment. Upon comparison of tryptic phosphopeptide maps of the glucocorticoid receptor, two unique phosphopeptides were detected after okadaic acid-treatment (DeFranco et al., 1991). Apparently, these phosphopeptides represent the site(s) which need to be dephosphorylated before the glucocorticoid receptor can recycle to the nuclear compartment. The effectiveness of glucocorticoid action can vary through the cell cycle. Glucocorticoids regulate epidermal growth factor (EGF) receptors in HeLa S3 
cells in a reversible and cell cycle dependent manner. To be effective with regard to EGF receptor upregulation, glucocorticoids must be present during the late G1 and S phases, while they are ineffective during the G2/M and early G1 phases of the cell cycle (Fanger et al., 1986). Cells in the late G1 and S phases had consistently more nuclear glucocorticoid receptor compared to cells in the G2/M and early G1 phases. Site-specific alterations in glucocorticoid receptor phosphorylation were observed in mouse $L$ cell fibroblasts during synchronization in the G2 phase, as compared to unsynchronized cells (Hsu et al., 1992). Together, these studies suggest that the subcellular distribution of the glucocorticoid receptor is influenced by its phosphorylation state.

\subsubsection{Role of phosphorylation in DNA binding and trans-activation by the 1,25-dihydroxyvitamin $\mathrm{D}_{3}$ receptor}

Treatment of CV-1 cells expressing the 1,25-dihydroxyvitamin $D_{3}$ receptor with either $8 \mathrm{Br}$-cAMP or okadaic acid and/or 1,25-dihydroxyvitamin $\mathrm{D}_{3}$ resulted in trans-activation from a reporter gene in a receptor dependent fashion (Darwish et al., 1993). Under these conditions there was increased phosphorylation of the 1,25-dihydroxyvitamin $\mathrm{D}_{3}$ receptor (Darwish et al., 1993). These results suggest that phosphorylation plays a central role in the trans-activation function of the 1,25-dihydroxyvitamin $\mathrm{D}_{3}$ receptor. Also in COS-7 cells the 1,25-dihydroxyvitamin $\mathrm{D}_{3}$ receptor could be phosphorylated by protein kinase A (Jurutka et al., 1993C). The actual site(s) of 1,25-dihydroxyvitamin $\mathrm{D}_{3}$ receptor phosphorylation by protein kinase $\mathrm{A}$ have not been identified. The human 1,25-dihydroxyvitamin $D_{3}$ receptor is selectively phosphorylated by protein kinase $C$ on serine at position 51 in CV-1 cells (Hsieh et al., 1991). This serine residue is located in a position between the two zinc fingers that constitute the DNA binding domain of the receptor. Substitution of this serine residue by a negatively 
charged aspartic acid residue markedly reduced the binding of the receptor to a vitamin D-responsive element in vitro, and also reduced the 1,25-dihydroxyvitamin $\mathrm{D}_{3}$ receptor-mediated transcription from a reporter gene in COS-7 cells (Hsieh et al., 1993). Substitution of serine 51 by alanine in the human 1,25 dihydroxyvitamin $\mathrm{D}_{3}$ receptor reduced receptor phosphorylation in COS-7 cells, but preserved completely the DNA binding activity in vitro and also the transactivation capacity. So, phosphorylation at serine residue 51 is not required for either DNA binding or trans-activation of the 1,25-dihydroxyvitamin $\mathrm{D}_{3}$ receptor. It has been suggested that phosphorylation at serine residue 51 could silence the 1,25-dihydroxyvitamin $\mathrm{D}_{3}$ receptor via a negative regulation of DNA binding when target cells are subject to protein kinase $\mathrm{C}$ activation events (Hsieh et al., 1993). In osteoblast-like cells the 1,25-dihydroxyvitamin $D_{3}$ stimulated synthesis of osteocalcin could be inhibited by several protein kinase $\mathrm{C}$ inhibitors (van Leeuwen et al., 1992), demonstrating a possible functional involvement of protein kinase $\mathrm{C}$ in the action of vitamin $\mathrm{D}$ on bone, although phosphorylation of the 1,25-dihydroxyvitamin $\mathrm{D}_{3}$ receptor was not investigated.

\subsection{Conclusions}

Steroid hormone receptors are present in target cells as parts of oligomeric complexes with heat-shock proteins. The receptors are already phosphorylated in the unliganded form. After binding of their respective ligands, receptors become rapidly extra phosphorylated. Kinetic studies have revealed that this extra phosphorylation is preceded by dissociation of heat-shock proteins (notably hsp90) from the complex. Most of the phosphorylation sites identified so far, are

located in the $\mathrm{N}$-terminal domain. In the progesterone receptor protein one site is located in the hinge region, and in the 1,25-dihydroxyvitamin $\mathrm{D}_{3}$ receptor one 
site was reported to reside in the DNA binding domain. Serine is the main phosphorylated amino acid residue in steroid hormone receptors. Only the estrogen receptor is reported to be phosphorylated on tyrosine residues, although also phosphorylation on serine residues has been reported by various groups. Most of the sites that have been identified so far are only partially phosphorylated. This is in agreement with findings on steroid hormone receptor heterogeneity, showing that within a cell several subpopulations of receptors exist, each with different numbers or patterns of phosphorylated amino acids. Possibly differential phosphorylation of the same steroid hormone receptor molecule is involved in the regulation of different receptor functions. Most of the sites in progesterone-, glucocorticoid-, and estrogen receptors are homologous with consensus sequences for the proline-directed protein kinases. These kinases are involved in regulation of the cell cycle, suggesting a possible link between steroid hormone receptor phosphorylation and the cell cycle. The sensitivity of cells to steroid hormones could vary through the cell cycle, depending on receptor phosphorylation degree and pattern. Functions of receptors that are regulated by phosphorylation are only beginning to be investigated. Steroid hormone receptor phosphorylation might have a role in transcriptional regulation, regulation of steroid binding capacity, nucleocytoplasmic shuttling and DNA binding capacity.

Analysis of transcriptional promoters for RNA polymerase II has revealed that the precise selection of a start site and the efficiency of transcription are imparted by a variety of cis-acting elements that flank the transcription initiation site. The TATA box binds the general transcription factor TFIID-complex and directs the assembly of the general transcriptional apparatus on the promoter DNA. The efficiency of transcription initiation is affected by a group of sequence-specific DNA binding regulatory transcription factors, such as Spl and 
CCAAT box binding proteins. Steroid hormone receptors can stimulate transcription by binding to enhancer elements at a relatively large distance from the transcriptional start site. By regulation of the activity of upstream regulatory factors, transcription is modulated in response to physiological stimuli such as hormones, growth factors, and vitamins. At present, it is not known in detail how phosphorylation influences transcriptional activation potential. Domains rich in acidic amino acid residues are often important for the activity of transcription factors, and phosphorylation might exert its effects by simply contributing extra negative charge (Ptashne, 1988). In Figure 2.2, a model for steroid hormone receptor- mediated transcription activation is depicted. The steroid hormone receptor molecule becomes extra phosphorylated in or close to a transcription activation domain after hormone binding, thereby activating transcription from a target gene promoter. Evidence for such a model is provided for the progesterone-, estrogen , and 1,25-dihydroxyvitamin $\mathrm{D}_{3}$ receptors (section 2.7).

Regulation of steroid hormone receptor activity via regulation of steroid hormone binding capacity would be an attractive model. However, only for the estrogen receptor some evidence for such a model has been found (see paragraph 2.6). The non- or under-phosphorylated estrogen receptor is unable to bind steroid. Only upon phosphorylation by a tyrosine protein kinase the receptor is able to bind hormone with high affinity. Phosphorylation may cause a conformational change in the ligand binding domain, enabling steroid binding. Alternatively, phosphorylation of the receptor may lead to dissociation or inactivation of a factor inhibiting steroid binding. The effect of ATP on the steroid binding capacity of the glucocorticoid receptor (paragraph 2.2) is probably due to an ATP dependent association of hsp90 to the receptor (Hu et al., 1994), and is not associated with phosphorylation of the receptor itself. Binding of hsp90 to the glucocorticoid receptor was shown to be essential for 
the formation of a high affinity ligand binding receptor (Bresnick et al. 1989).

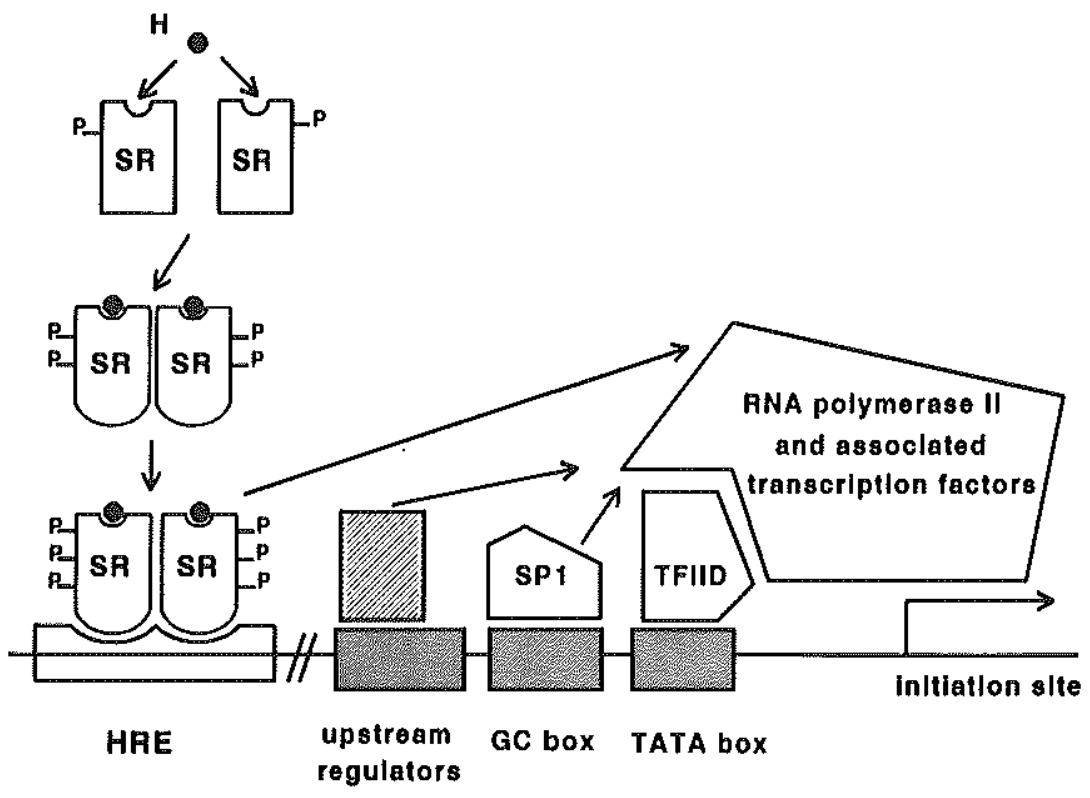

Figure 2.2. Schematic representation of steroid hormone receptor (SR) phosphorylation and transcription activation.

Depending on the cell type, steroid hormone receptors are located to a considerable extent in the cell nucleus already in the absence of hormone. Upon addition of hormone, receptors become extra phosphorylated and translocate rapidly to the cell nucleus. Steroid receptors probably can return to the cytoplasmic compartment. Only for the glucocorticoid receptor some evidence for a role of receptor phosphorylation in the regulation of receptor subcellular 
location was provided (paragraph 2.7.4).

Phosphorylation of steroid hormone receptors in the DNA binding domain might influence their ability to bind to DNA. Evidence for such a model, however, is limited. Only for the 1,25-dihydroxyvitamin $D_{3}$ receptor some evidence is available for a negative effect of phosphorylation in the DNA binding domain on specific DNA binding (paragraph 2.7.5).

Future advances will depend on the identification, and elucidation of the regulation, of all kinases and phosphatases involved in steroid hormone receptor phosphorylation. Additional mutagenesis studies of phosphorylation sites might help to further elucidate and understand the consequences of the introduction of a negatively charged phosphate group for the activity of steroid hormone receptors. 



\section{REFERENCES}

Adler, A.J., Danielsen, M. and Robins, D.M. (1992) Androgen specific gene activation via a consensus glucocorticoid response element is determined by interaction with non receptor factors. Proc. Natl. Acad. Sci. USA $\underline{89}$, 11660-11663.

Adler, A.J., Scheller, A. and Robins, D.M. (1993) The stringency and magnitude of androgen specific gene activation are combinatorial functions of receptor and non-receptor binding sites. Mol. Cell. Biol. 13, 6326-6335.

Ali, S., Metzger, D., Bornert, J.-M. and Chambon, P. (1993) Modulation of transcriptional activation by ligand dependent phosphorylation of the human oestrogen receptor $\mathrm{A} / \mathrm{B}$ region. EMBO J. $\underline{12}, 1153-1160$.

Allan, G.F., Tsai, S.Y., Tsai, M.-J. and O'Malley, B.W. (1992) Ligand dependent conformational changes in the progesterone receptor are necessary for events that follow DNA binding. Proc. Natl. Acad. Sci. $\underline{89}$, 11750-11754.

Alnemri, E.S., Maksymowych, A.B., Robertson, N.M. and Litwack, G. (1991) Overexpression and characterization of the human mineralocorticoid receptor. J. Biol. Chem. 266, 1807218081.

Anderson, K.M. and Liao, S. (1968) Selective retention of dihydrotestosterone by prostatic nuclei. Nature 219, 277-279.

Aronica, S.M. and Katzenellenbogen, B.S. (1991) Progesterone receptor regulation in uterine cells: stimulation by estrogen, cAMP, insulin like growth factor $I$ and suppression by antiestrogens and protein kinase inhibitors. Endocrinology 128, 2045-2052.

Aronica, S.M. and Katzenellenbogen, B.S. (1993) Stimulation of estrogen receptor mediated transcription and alteration in the phosphorylation state of the rat uterine estrogen receptor by estrogen, cyclic adenosine monophosphate and insulin-like growth factor $I$. Mol. Endocrinol. 7, 743-751.

Auricchio, F. and Migliaccio, A. (1980) In vitro inactivation of oestrogen receptor by nuclei. FEBS Lett. 117, 224-226.

Auricchio, F. Migliaccio, A., Rotondi, A. and Castoria, G. (1985) Phosphorylation on tyrosine of the estrogen receptor. In: Molecular mechanism of steroid hormone action, pp. 279298. Ed. V.K. Moudgil, Walter de Gruyler-Berlin.

Auricchio, F. (1989) Phosphorylation of steroid receptors. J. Steroid Biochem. $\underline{32}$, 613-622. Baarends, W., Themmen, A., Blok, L., Mackenbach, P., Brinkmann, A., Meyer, D., Faber,P., Trapman, J. and Grootegoed, J.A. (1990) The rat androgen receptor promoter. Mol.Cell. Endocrinol. 74, 75-84.

Bagchi, M.K., Tsai, S.Y., Tsai, M-Y. and O'Malley, B.W. (1992) Ligand and DNA-dependent phosphorylation of human progesterone receptor in vitro. Proc. Natl. Acad. Sci. USA $\underline{89}$, 2664-2668.

Bai, W., Tullos, S. and Weigel, N.L. (1994) Functional analysis of chicken progesterone receptor phosphorylation site mutants. Endocrine Society 76th meeting, Abstract nr. 1720.

Bardin, C.W. and Catterall, J.F. (1981) Testosterone: a major determinant of extragenital sexual dimorphism. Science 211, 1285-1294.

Barrack, E.R. (1983) The nuclear matrix of the prostate contains acceptor sites for androgen receptors. Endocrinology 113, 430-432.

Beato, M. (1989) Gene regulation by steroid hormones. Cell $\underline{56}, 335-344$. 
Beck, C.A., Weigel, N.L. and Edwards, P. (1992) Effects of hormone and cellular modulators of protein phosphorylation on transcriptional activity, DNA binding and phosphorylation of human progesterone receptor. Mol. Endocrinol. $\underline{6}$, 607-620.

Becker, P.M., Gloss, B., Schmid, W., Strähle, U. and Schiitz, G. (1986) In vivo protein DNA interactions in a glucocorticoid response element requires the presence of the hormone. Nature $\underline{324}$, 686-688.

BelI, P.A. and Munck, A. (1973) Steroid binding properties and stabilization of cytoplasmic glucocorticoid receptors from rat thymus cells. Biochem. J. 136, 97-107.

Bodwell, J.E., Orti, E., Coull, J.M., Pappin, D.J.C., Mendel, D.B., Smith, L.I. and Swift, F. (1991) Identification of phosphorylation sites in the mouse glucocorticoid receptor.

J. Biol. Chem. 266, 7549-7555.

Bökenkamp, D., Jungblut, P.W. and Thole, H. (1994) The C-terminal hatf of the porcine estradiol receptor contains no post-translational modification: determination of the primary structure. Mol.Cell.Endocrinol. 104, 163-172.

Bonne, C. and Raynaud, J.P. (1975) Methyltrienolone, a specific ligand for cellular androgen receptors. Steroids 26, 227-236.

Bresnick, E.H., Dalman, F.C., Sanchez, E.R. and Pratt, W.B. (1989) Evidence that the $90 \mathrm{kDa}$ heat shock protein is necessary for the steroid binding conformation of the L-cell glucocorticoid receptor. J. Biol. Chem. 264, 4992-4997.

Brink, M., Humbel, B.M., de Kloet, E.R. and van Driel, R. (1992) The unliganded glucocorticoid receptor is localized in the nucleus, not in the cytoplasm. Endocrinology $130,3575-3581$.

Brinkmann, A.O., Kuiper, G., de Boer, W., Mulder, E. and van der Molen, H.J. (1985) Photoaffinity labelling of androgen receptor with $17 \beta$-hydroxy-17 $\alpha-\left[{ }^{3} \mathrm{H}\right]$-methyl-4,9,11 estratrien-3-one. Biochem.Biophys.Res.Commun. 126, 163-169.

Brinkmann, A.O., Kuiper, G., Bolt-de Vries, J. and Mulder E. (1988) In situ photolabelling of the human androgen receptor. J. Steroid Biochem. 30, 257-261.

Brinkmann, A.O., Faber, P.W., van Rooij, H., Kuiper, G., Klaasen, P., van der Korput, J., Voorhorst, M., van Laar, J., Mulder, E. and Trapman, J. (1989) The human androgen receptor: domain structure, genomic organization and regulation of expression. J. Steroid Biochem. 34, 307-310.

Brinkmann, A.O. and Trapman, J. (1992) Androgen receptor mutants that affect normal growth and development. Cancer Surveys $14,95-111$.

Brown, T.A. and DeLuca, H.F. (1990) Phosphorylation of the 1,25-dihydroxyvitamin D3 receptor. J.Biol.Chem. 265, 10025-10029.

Brown, T.A. and DeLuca, H.F. (1991) Sites of phosphorylation and photoaffinity labelling of the 1,25-dihydroxyvitamin D3 receptor. Arch. Biochem. Biophys. 286, 466-472.

Brown, C.J., Goss, S.J., Lubahn, D.B., Joseph, D.R., Wilson, E.M., French, F.S. and Willard, H.F. (1989) Androgen receptor locus on the human X chromosome: regional localization to Xq 11-12 and description of a DNA polymorphism. Am. J. Hum. Genet. 44, 264-269.

Bruchovsky, N. and Wilson, J.D. (1968) The intranuclear binding of testosterone and $5 \alpha-$ androstan-17ß-ol-3-one by rat prostate. J. Biol. Chem. 243, 5953-5960.

Buttyan, R., Olsson, C.A. Sheard, B. and Kallos, J. (1983) Steroid receptor-nuclear matrix interactions. The role of DNA. J. Biol. Chem. 258, 14366-14370.

Castoria, G., Migliaccio, A., Green, S., Di Domenico, M., Chambon, P. and Auricchio, F. (1993) Properties of a purified estradiol-dependent calf uterus tyrosine kinase. Biochemistry, $\underline{32}, 1740-1750$. 
Chang, C.H., Rowley, D.R. and Tindall, D.J. (1983) Purification and characterization of the androgen receptor from rat ventral prostate. Biochemistry 22, 6170-6175.

Chang, C.H., Lobl, T.J., Rowley, D.R. and Tindall, D.J. (1984) Affinity labeling of the androgen receptor in rat prostate cytosol with $17 \beta$-[(bromoacetyl)-oxy]-5- $\alpha$-androstan- 3 one. Biochemistry, 23, 2527-2533.

Chang, C., Kokontis, J, and Liao, S. (1988A) Molecular cloning of human and rat complementary DNA encoding androgen receptors. Science $240,324-326$.

Chang, C., Kokontis, J. and Liao, S. (1988B) Structural analysis of complementary DNA and amino acid sequences of human and rat androgen receptors. Proc. Natl. Acad. Sci. USA $\underline{85}, 7211-7215$.

Chauchereau, A., Loosfelt, H. and Milgrom, E. (1991) Phosphorylation of transfected wild type and mutated progesterone receptors. J. Biol. Chem. 266, 18280-18286.

Claessens, F., Celis, L., Peeters, B., Heyns, W., Verhoeven, G. and Rombauts, W. (1989) Functional characterization of an androgen response element in the first intron of the C3(1) gene of prostatic binding protein. Biochem. Biophys. Res. Commun. $\underline{164}, 833-840$.

Colvard, D.S. and Wilson, E.M. (1981) Identification of an $8 \mathrm{~S}$ androgen receptor promoting factor that converts the $4.5 \mathrm{~S}$ form of the androgen receptor to 8S. Endocrinology 109 , 496-504.

Colvard, D.S. and Wilson, E.M. (1984) Androgen receptor binding to nuclear matrix in vitro and its inhibition by $8 \mathrm{~S}$ androgen receptor promoting factor. Biochemistry 23, 3479-3486.

Colvard, D.S. and Wilson, E.M. (1987) Transformation of the $10 \mathrm{~S}$ androgen receptor in a hamster ductus deferens tumor cell line. Endocrinology 121, 931-940.

Conneely, O., Sullivan, W., Toft, D., Birnbaumer, M., Cook, R., Maxwell, B., Zarucki-Schulz, T., Greene, G., Schrader, W. and O'Malley, B.W. (1986) Molecular cloning of the chicken progesterone receptor. Science $233,767-770$.

Crozat, A., Palvimo, J.J., Jukkunen, M. and Jänne, O. (1992) Comparison of androgen regulation of ornithine decarboxylase and S-adenosylmethionine decarboxylase gene expression in rodent kidney and accessory sex organs. Endocrinology $\underline{130}$, 1131-1143.

Dahlman-Wright, K., Almlof, T., McEwan, I.J., Gustafsson, J-A. and Wright, A.P.H. (1994) Delineation of a small region within the major transactivation domain of the human glucocorticoid receptor that mediates transactivation of gene expression. Proc. Natl. Acad. Sci. USA 91, 1619-1623.

Dalman, F.C., Sanchez, E.R., Lin, A.L-Y., Perini, F, and Pratt, W.B. (1988) Localization of phosphorylation sites with respect to the functional domains of the mouse $\mathrm{L}$ cell glucocorticoid receptors. J. Biol, Chem. 263, 12259-12267.

Danielsen, M., Northrop, J.P. and Ringold, G.M. (1986) The mouse glucocorticoid receptor: mapping of functional domains by cloning, sequencing and expression of wild type and mutant receptor proteins. EMBO J. $\underline{5}, 2513-2522$.

Danielsen, M., Northrop, J.P., Jonklaas, J. and Ringold, G.M. (1987) Domains of the glucocorticoid receptor involved in deoxyribonucleic acid binding, hormone activation and transcriptional enhancement. Mol. Endocrinol. $\underline{1}, 816-822$.

Darwish, H.M., Burmester, J.K., Moss, V.E. and DeLuca, H.F. (1993) Phosphorylation is involved in transcriptional activation by the 1,25-dihydroxyvitamin $\mathrm{D}_{3}$ receptor. Biochim. Biophys. Acta 1167, 29-36.

Davies, P. and Thomas, P. (1984) Interaction of androgen receptors with chromatin and DNA. J.Steroid Biochem. 20, 57-65. 
Davies, P., Elford, C., Manning, D., Phillips, E., Rushmere, N. and Thomas, P. (1985) Regulatory significance of receptor chromatin associations. In: Regulation of androgen action. Eds. Bruchovsky, N., Chapdelaine, A. and Neumann, F. Congressdruck BriicknerBerlin., pp. 159-164.

Davies, P. and Rushmere, N.K. (1988) Regulatory regions of androgen responsive genes. Biochem. Soc. Trans. 16, 695-698.

Dayani, N., McNaught, R.W., Shenolikar, S. and Smith, R.G. (1990) Receptor interconversion model of hormone action II. Biochemistry 29, 2691-2698.

de Boer, W., Lindh, M., Bolt, J., Brinkmann, A.O. and Mulder, E. (1986A) Characterization of the calf uterine androgen receptor and its activation to the deoxyribonucleic acid binding state. Endocrinology 118, 851-861.

de Boer, W., Bolt, J., Brinkmann, A.O. and Mulder,E. (1986B) Differential effects of molybdate on the hydrodynamic and DNA binding properties of the non-activated and activated forms of the androgen receptor in calf uterus. Biochim.Biophys.Acta $\underline{898}, 240$ 250.

de Boer, W., Bolt, J., Kuiper,G., Brinkmann, A.O. and Mulder, E. (1987) Analysis of steroidand DNA binding domains of the calf uterine androgen receptor by limited proteolysis. J.Steroid Biochem. 28, 9-19.

De Vos, P., Claessens, F., Winderickx, J., van Dijck, P., Celis, L., Peeters, B., Rombauts, W., Heijns, W. and Verhoeven, G. (1991) Interaction of androgen response elements with the DNA binding domain of the rat androgen receptor expressed in E. Coli. J. Biol. Chem. $\underline{266}, 3439-3443$.

Devos, A., De Clercq, N., Vercaeren, J., Heyns, W., Rombauts, W. and Peeters, B. (1993) Structure of rat genes encoding androgen-regulated cystatin-related proteins (CRPs): a new member of the cystatin superfamily. Gene 125, 159-167.

De Vos, P., Schmitt, J., Verhoeven, G. and Stunnenberg, H.G. (1994). Human androgen receptor expressed in HeLa cells activates transcription in vitro. Nucleic Acid. Res. 22, 1161-1166.

DeFranco, D.B., Qi, M., Borror, K.C., Garabedian, M.J. and Brautigan, D.L. (1991) Protein phosphatase 1 and/or 2 A regulate nucleocytoplasmic shuttling of glucocorticoid receptors. Mol. Endocrinol. 5, 1215-1227.

Denis, M., Poellinger, L., Wikström, A.C. and Gustafsson, J.A. (1988) Requirement of hormone for thermal activation of the glacocorticoid receptor to a DNA binding state. Nature 333, 686-688.

Denner, L.A., Bingman, W.E., Greene, G.L. and Weigel, N.L. (1987) Phosphorylation of the chicken oviduct progesterone receptor. J.Steroid Biochem. 27, 235-243.

Denner, L.A., Schrader, W.T. O'Malley, B.W. and Weigel, N.L. (1990A) Hormonal regulation and identification of chicken progesterone receptor phosphorylation sites. J.Biol. Chem. 265, 16548-16555.

Denner, L.A., Weigel, N.L., Maxwell, B.L., Schrader, W.T. and O'Malley, B.W. (1990B) Regulation of progesterone receptor mediated transcription by phosphorylation. Science $250,1740-1743$.

Denton, R.R., Koszewski, N.J. and Notides, A.C. (1992) Estrogen receptor phosphorylation. J. Biol. Chem. 267, 7263-7268.

Dingwall, C. and Laskey, R.A. (1991) Nuclear targeting sequences - a consensus? Trends Biochem. Sci. 16, 478-481. 
Dobson, A.D.W., Conneely, O., Beatti, W., Maxwell, B.L., Mak. P., Tsai, M-J, Schrader, W.T. and O'Malley, B.W. (1989) Mutational analysis of the chicken progesterone receptor. J. Biol. Chem. 264, 4207-4211.

Dong, Y., Aronsson, M., Gustafsson, J.A. and Okret, S. (1989) The mechanism of cAMP induced glucocorticoid receptor expression: correlation to cellular glucocorticoid response. J. Biol, Chem. 264, 13678-13683.

Dougherty, J.J., Puri, R.K. and Toft, D.O. (1982) Phosphorylation in vivo of chicken oviduct progesterone receptor. J. Biol. Chem. 257, 14226-14230.

Eliezer, N., Hurd, C.B. and Moudgil, V.K. (1987) Immunologically distinct binding molecules for progesterone and RU 38486 in the chicken oviduct cytosol. Biochim. Biophys. Acta 929, 34-39.

Eriksson, P. and Wränge, O. (1993) The glucocorticoid receptor acts as an antirepressor in receptor dependent in vitro transcription. Eur. J. Biochem. 215, 505-511.

Faber, P.W., Kuiper, G., van Rooij, H., van der Korput, J., Brinkmann, A.O. and Trapman, J. (1989) The N-terminal domain of the human androgen receptor is encoded by one large exon. Mol.Cell.Endocrinol. 61, 257-262.

Faber, P.W., King, A., van Rooij, H., Brinkmann, A.O., de Both, N.J, and Trapman, J. (1991A) The mouse androgen receptor: functional analysis of the protein and characterization of the gene. Biochem. J. 278, 269-278.

Faber, P.W., van Rooij, H., van der Korput, J., Baarends, W.M., Brinkmann, A.O., Grootegoed, J.A. and Trapman, J. (1991B) Characterization of the human androgen receptor transcription unit. J. Biol. Chem. 266, 10743-10749.

Fabre, S., Manin, M., Pailhoux, E.M., Veyssière, G. and Jean, C. (1994) Identification of a functional androgen response element in the promoter of the gene for the androgen regulated aldo keto reductase-like protein specific to the mouse vas deferens. J. Biol. Chem. 269, 5857-5864.

Fanger, B.O., Currie, R.A. and Cidlowski, J.A. (1986) Regulation of epidermal growth factor receptors by glucocorticoids during the cell cycle in Hela S3 cells. Arch. Biochem. Biophys. 249, 116-125.

Fawell, S.E., Lees, J.A., White, R. and Parker, M.G. (1990) Characterization and colocalization of steroid binding and dimerization activities in the mouse estrogen receptor. Cell $\underline{60}, 953-962$.

Foekens, J.A., Peerbolte, R., Mulder, E. and van der Molen, H.J. (1981). Characterization and partial purification of androgen receptors from ram seminal vesicles. Molec. Cell. Endocrinol. 23, 173-186.

Foekens, J.A., Mulder, E., Vrij, L. and van der Molen, H.J. (1982) Purification of the androgen receptor of sheep seminal vesicles. Biochem. Biophys. Res. Commun. 104, $1279-1286$.

Foekens, J.A., Rennie, P.S., Cheng, H. and Bruchovsky, N. (1985) In situ cross-linking of androgen receptors to nuclear acceptor sites of rat prostate with formaldehyde. J. Biol. Chem. 260, 10093-10098.

Forsgren, B., Bjork, P., Carlstrom, K., Gustafsson, J.A., Pousette, A. and Hogberg, B. (1979) Purification and distribution of a major protein in rat prostate that binds estramustine, a nitrogen mustard derivative of estradiol 17B. Proc. Natl. Acad. Sci. USA 76, 3149-3153.

Freedman, L.P. (1992) Anatomy of the steroid receptor zinc finger protein. Endocrine Reviews $\underline{13}$, 129-145. 
Garcia, T., Jung-Testas, I, and Baulieu, E.E. (1986A) Tightly bound nuclear progesterone receptor is not phosphorylated in primary chick oviduct cultures. Proc. Nat1. Acad. Sci. USA $83,7573-7577$.

Garcia, T., Buchou, T., Renoir, J.-M., Mester, J. and Baulieu, E.-E. (1986B) A protein kinase copurifies with chick oviduct progesterone receptor. Biochemistry 25, 7937-7942.

Gaspar, M.L., Meo, T. and Tosi, M. (1990) Structure and size distribution of the androgen receptor mRNA in wild type and Tfm/y mutant mice. Mol. Endocrinol. 4 , 1600-1610.

Golding, T.S. and Korach, K.S. (1988) Nuclear estrogen receptor molecular heterogeneity in the mouse uterus. Proc. Natl. Acad. Sci. USA 85, 69-73.

Gorski, J., Toft, D., Shyamala, G., Smith, D. and Notides, A. (1968) Hormone receptors: studies on the interaction of estrogen with the uterus. Recent Prog. Horm. Res. 24, 45-80.

Goueli, S.A. Holtzman, J.L. and Ahmed, K. (1984) Phosphorylation of the androgen receptor by a nuclear cAMP-independent protein kinase. Biochem. Biophys. Res. Commun. $\underline{123}$, $778-784$.

Govindan, M.V., Devic, M., Green, S., Gronemeyer, H. and Chambon, P. (1985) Cloning of the human glucocorticoid receptor cDNA. Nucleic Acids'Res. $\underline{13}, 8293-8304$.

Grandics, P., Miller, A., Schmidt, T.J. and Litwack, G. (1984) Phosphorylation in vivo of rat hepatic glucocorticoid receptor. Biochem. Biophys. Res. Commun. 120, 59-65.

Green, S., Walter, P., Kumar, V., Krust, A., Bornert, J.M., Argos, P. and Chambon, P. (1986) Human estrogen receptor cDNA: sequence, expression and homology to v-erb-A. Nature $\underline{320}, 134-139$.

Griffin, J.E. and Wilson, J.D. (1992) Disorders of the testes and the male reproductive tract. In: Textbook of Endocrinology, 8th edition. Eds: J.D. Wilson and D.W. Foster. W.B. Saunders Company.

Grody, W.W., Compton, J.G., Schrader, W.T. and O'Malley, B.W. (1980) Inactivation of chick oviduct progesterone receptors. J. Steroid. Biochem. 12, 115-120.

Gronemeyer, H. and Govindan, M.V. (1986) Affinity labelling of steroid hormone receptors. Mol. Cell. Endocrinol. 46, 1-19.

Gronemeyer, H., Turcotte, B., Quirin-Stricker, C., Bocquel, M.T., Meyer, M.E., Krozowski, Z., Jeltsch, J.M., Leronge, T., Garnier, J.M. and Chambon, P. (1987) The chicken progesterone receptor: sequence, expression and functional analysis. EMBO J. $\underline{6}, 3985-$ 3994.

Gronemeyer, H., Benhamou, B., Berry, M., Bocquil, M.T., Gofflo, D., Garcia, T., Lerouge, T., Metzger, D., Meyer, M.E., Tora, L., Vergezac, A. and Chambon, P. (1992) Mechanisms of antihormone action. J. Steroid Biochem. Molec. Biol. 41, 217-221.

Groyer, A., Le Boue, Y., Joab, I., Radanyi, C., Renoir, J-M., Robel, P. and Baulieu, E.E. (1985) Chicken oviduct glucocorticosteroid receptor, Eur. J. Biochem. 149, 445-451.

Groyer, A., Schweizer-Groyer, G., Cadepond, F., Mariller, M. and Baulieu, E.E. (1987) Antiglucocorticoid effects suggest why steroid hormone is required for receptors to bind DNA in vivo but not in vitro. Nature $328,624-626$.

Gyorki, S., James, R., Warne, G.L. and Funder, J.W. (1986) Photoaffinity labelling of androgen receptors from human foreskin and cultured genital fibroblasts with tritiated methyltrienolone (R1881). J. Steroid Biochem. 25, 355-358.

Gyorki, S., Warne, G.L. and Funder, J.W. (1988) Photoaffinity labelling with [ $\left.{ }^{3} \mathrm{H}\right]-\mathrm{R} 1881$ of androgen receptors from human cultured genital fibroblasts of normal individuals and patients with androgen receptor abnormalities. J. Steroid Biochem. 29, 611-615. 
Ham, J., Thomson, A., Needham, M., Webb, P. and Parker, M.G. (1988) Characterization of response elements for androgens, glucocorticoids and progestins in mouse mammary tumour virus. Nucl. Acids Res 16, 5263-5277.

Härd, T,, Kellenbach, E., Boelens, R., Maler, B.A., Dahlman, K., Freedman, L.P., Carlstedt -Duke, J., Yamamoto, K., Gustaffson, J.-A. and Kaptein, R. (1990) Solution structure of the glucocorticoid receptor DNA binding domain. Science $249,157-160$.

Härd, T, and Gustafsson, J.-A. (1993) Structure and function of the DNA-binding domain of the glucocorticoid receptor and other members of the nuclear receptor supergene family. Accounts of Chemical Research 26, 644-650.

Harding, B.W. and Samuels, L.T. (1962) The uptake and subcellular distribution of ${ }^{14} \mathrm{C}-$ labeled steroid in rat ventral prostate following in vivo administration of testosterone-4${ }^{14} \mathrm{C}$. Endocrinology 70, 109-118.

He, W.W., Fisher, L.M., Sun, S., Bilhartz, D.L., Zhu, X., Young, C.Y.F., Kelly, D.B. and Tindall, D.J. (1990) Molecular cloning of androgen receptor from divergent species with a polymerase chain reaction technique. Biochem. Biophys. Res. Commun. 171, 697-704.

Hilliard, G.M., Cook, R.G., Weigel, N.L. and Pike, J.W. (1994) 1,25-dihydroxyvitamin $D_{3}$ modulates phosphorylation of serine 205 in the human vitamin $\mathrm{D}$ receptor: site directed mutagenesis of this residue promotes alternative phosphorylation. Biochemistry $\underline{33}, 4300$ 4311 .

Hoeck, W., Rusconi, S. and Groner, B. (1989) Down-regulation and phosphorylation of glucocorticoid receptors in cultured cells. J. Biol. Chem. 264, 14396-14402.

Hoeck, W. and Groner, B. (1990) Hormone dependent phosphorylation of the glucocorticoid receptor occurs mainly in the amino-terminal transactivation domain. J. Biol. Chem. 265, 5403-5408.

Hollenberg, S.M., Weinberger, C., Ong, E.S., Cerelli, G., Oro, A., Lebo, R., Thompson, E.B., Rosenfeld, M.G. and Evans, R.M. (1985) Primary structure and expression of a functional human glucocorticoid receptor cDNA. Nature 318, 635-641.

Horwitz, K.B., Francis, M.D. and Wei, L.L. (1985) Hormone-dependent covalent modification and processing of human progesterone receptors in the nucleus. DNA $\underline{4}, 451-460$.

Housley, P.R. and Pratt, W.B. (1983) Direct demonstration of glucocorticoid receptor phosphorylation by intact L-cells. J. Biol.Chem. 258, 4630-4635.

Housley, P.R., Sanchez, E.R., Westphal, M., Beato, M. and Pratt, W.B. (1985) The molybdate stabilized $\mathrm{L}$ cell glucocorticoid receptor isolated by affinity chromatography is associated with an 90-92 kDa non-steroid binding phosphoprotein. J. Biol. Chem. 260, 13810-13817.

Hsieh, J., Jurutka, P.W., Galligan, M.A., Terpening, C.M., Haussler, C.A., Samuels, D.S., Shimizu, Y., Shimizu, N. and Haussler, M. (1991) Human vitamin D receptor is selectively phosphorylated by protein kinase $\mathrm{C}$ on serine 51 , a residue crucial to its transactivation function. Proc. Natl. Acad. Sci, 88 , 9315-9319.

Hsieh, J., Jurutka, P.W., Nakajima, S., Galligan, M.A., Haussler, C.A., Shimizu, Y., Shimizu, N., Whitfield, K. and Haussler, M. (1993) Phosphorylation of the human vitamin D receptor by protein kinase C. J. Biol. Chem. 268, 15118-15126.

Hst, S., Qi, M. and DeFranco, D.B. (1992) Cell cycle regulation of glucocorticoid receptor function. EMBO J. 11, 3457-3468.

Hu, L-M., Bodwell, J., Hu, J-M., Orti, E. and Munck, A. (1994) Glucocorticoid receptors in ATP-depleted cells. J. Biol. Chem. 269, 6571-6577.

Hubbard, M.J. and Cohen, P. (1993) On target with a new mechanism for the regulation of protein phosphorylation. Trends Biochem. Sci, 18, 172-177. 
Hunter, T. and Karin, M. (1992) The regulation of transcription by phosphorylation. Cell $\underline{70}$, 375-387.

Hurd, C., Nakao, M. and Moudgil, V.K. (1989) Phosphorylation of calf uterine progesterone receptor by cAMP-dependent protein kinase. Biochem. Biophys. Res. Commun. 162, 160167.

Husmann, D.A., Wilson, C.M., McPhaul, M., Tilley, W. and Wilson, J.D. (1990) Antipeptide antibodies to two distinct regions of the androgen receptor localize the receptor protein to the nuclei of target cells in the rat and human prostate. Endocrinology 126, 2359-2368.

Hutchison, K.A., Dalman, F.D., Hoeck, W., Groner, B. and Pratt, W.B. (1993) Localization of the $12 \mathrm{kDa}$ discrepancy in gel migration of the mouse glucocorticoid receptor to the major phosphorylated cyanogen bromide fragment in the transactivating domain.

J. Steroid Biochem. Molec. Biol. 46, 681-686.

Jackson, S.P. (1992) Regulating transcription factor activity by phosphorylation. Trends Cell Biol. 2, 104-108.

Jackson, S., Gottlieb, T. and Hartley, K. (1993) Phosphorylation of transcription factor Spl by the DNA dependent protein kinase. Adv. in Sec. Mess. and Phosphoprot. Res. 28 , 279-286.

Jensen, E.V., Suzuki, T., Kawashima, T., Stumpf, W.E., Jungblut, P.W. and DeSombre, E.R. (1968) A two-step mechanism for the interaction of estradiol with rat uterus. Proc. Natl. Acad. Sci: USA 59, 632-637.

Jensen, E.V. and DeSombre, E.R. (1973) Estrogen-receptor interaction. Estrogenic hormones effect transformation of specific receptor proteins to a biochemically functional form. Science $182,126-134$.

Jensen, E.V. (1979) Interaction of steroid hormones with the nucleus. Pharmacol. Rev. $\underline{30}$, 477-491.

Jenster, G., van der Korput, H., van Vroonhoven, C., van der Kwast, Th., Trapman, J. and Brinkmann, A.O. (1991) Domains of the human androgen receptor involved in steroid binding, transcriptional activation, and subcellular localization. Mol. Endocrinol. $\underline{5}$, 13961404.

Jenster, G., Trapman, J. and Brinkmann, A.O. (1993) Nuclear import of the human androgen receptor. Biochem.J. 293,761-768.

Joab, I., Radanyi, C., Renoir, M., Buchou, T., Catelli, M.-G., Binart, N., Mester, J. and Baulieu, E-E. (1984) Common non-hormone binding component in non-transformed chick oviduct receptors of four steroid hormones. Nature $\underline{308}, 850-853$.

Jones, B.B., Jurutka, P.W., Haussler, C.A., Haussler, M.R. and Whitfield, G.K. (1991) Vitamin D receptor phosphorylation in transfected ROS 17/28 cells is localized to the Nterminal region of the hormone binding domain. Mol. Endocrinol. $5,1137-1145$.

Jurutka, P.W., Terpening, C.M. and Haussler, M.R. (1993A) The 1,25-dihydroxyvitamin $\mathrm{D}_{3}$ receptor is phosphorylated in response to vitamin $\mathrm{D}_{3}$ and 22-oxacalcitriol in rat osteoblasts, and by casein kinase II in vitro. Biochemistry $\underline{32}, 8184-8192$.

Jurutka, P.W., Hsieh, J.C., McDonald, P., Terpening, C.M., Haussler, C.A., Haussler, M.R. and Whitfield, G.K. (1993B) Phosphorylation of serine 208 in the human vitamin D receptor. J. Biol. Chem. 268, 6791-6799.

Jurutka, P.W., Hsieh, J.C. and Haussler, M.R. (1993C) Phosphorylation of the human 1,25dihydroxyvitamin $\mathrm{D}_{3}$ receptor by cAMP dependent protein kinase, in vitro and in transfected COS-7 cells. Biochem. Biophys. Res. Commun. 191, 1089-1096. 
Kallio, P.J., Palvimo, J.J., Mehto, M. and Jänne, O.A. (1994) Analysis of androgen receptor DNA interactions with receptor proteins produced in insect cells. J.Biol.Chem, 269 , 11514-11521.

Kaspar, F., Klocker, H., Denninger, A. and Cato, A.C.B. (1993) A mutant androgen receptor from patients with Reifenstein syndrome : identification of the function of a conserved alanine residue in the $\mathrm{D}$ box of steroid receptors. Mol.Cell.Biol. 13, 7850-7858.

Katzenellenbogen, J.A. and Katzenellenbogen, B.S. (1984) Affinity labeling of receptors for steroid and thyroid hormones. Vit.Horm. 41, 213-274.

Kemppainen, J.A., Lane, M.V., Sar, M. and Wilson, E.M. (1992) Androgen receptor phosphorylation, turnover, nuclear transport and transcriptional activation. J. Biol. Chem. 267, 968-974.

Klug, A. and Rhodes, D. (1987) Zinc fingers: a novel protein motif for nucleic acid recognition. Trends Biochem. Sci. $\underline{12}, 464-469$.

Kovacs, W.J., Griffin, J.E. and Wilson, J.D. (1983) Transformation of human androgen receptors to the deoxyribonucleic acid binding state. Endocrinology 113, 1574-1581.

Krempelhuber, A., Müller, F, and Fuhrmann, U. (1994) DNA binding of androgen receptor overexpressed in mammalian cells. J. Steroid Biochem. Molec. Biol. $\underline{48}, 511-516$.

Kuiper, G., Faber, P.W., van Rooij, H., van der Korput, J., Ris-Stalpers, C., Klaassen, P., Trapman, J. and Brinkmann, A.O. (1989) Structural organization of the human androgen receptor gene. J. Mol. Endocrin. 2, R1-R4.

Kuiper, G., de Ruiter, P.E., Trapman, J., Jenster, G. and Brinkmann, A.O. (1993) In vitro translation of androgen receptor cRNA results in an activated androgen receptor protein. Biochem. J. 296, 161-167.

Kuiper, G. and Brinkmann, A.O. (1994) Steroid hormone receptor phosphorylation: is there a physiological role? Mol.Cell.Endocrinol. 100, 103-107.

Lahooti, H., Thorsen, T, and Aakvaag, A. (1990) Phosphorylation of the estradiol receptor in MCF-7 human breast cancer cells in culture. Mol. Cell. Endocrinol. 74, 21-32.

Lahooti, H., White, R., Danielian, P.S. and Parker, M.G. (1994) Characterization of liganddependent phosphorylation of the estrogen receptor. Mol. Endocrinol. $\underline{8}, 182-188$.

Latchman, D.S. (1990) Eukaryotic transcription factors. Biochem. J. 270, 281-289.

LeGoff, P., Montano, M.M., Schodin, D.J. and Katzenellenbogen, B.S. (1994) Phosphorylation of the human estrogen receptor. J. Biol. Chem. 269, 4458-4466.

Liao, S. and Fang, S. (1969) Receptor proteins for androgens and the mode of action of androgens on gene transcription in ventral prostate. Vitam. Horm. 27, 17-90.

Liao, S., Tymoczko, J.L., Castaneda, E. and Liang, T. (1975) Androgen receptors and androgen-dependent initiation of protein synthesis in the prostate. Vitam. Horm. 33, 297317.

Liao, S. and Witte, D. (1985) Autoimmune anti-androgen receptor antibodies in human serum. Proc. Natl. Acad, Sci. USA 82, 8345-8348.

Logeat, F., Le Cunff, M., Pamphile, R. and Milgrom, E. (1985) The nuclear bound form of the progesterone receptor is generated through a hormone-dependent phosphorylation. Biochem. Biophys. Res. Commun. 131, 421-427.

Logeat, F., Le Cunff, M., Rauch, M,, Brailly, S. and Milgrom, E. (1987) Characterization of a casein kinase, which interacts with the rabbit progesterone receptor: differences with the in vivo hormone dependent phosphorylation. Eur. J. Biochem. $\underline{170}, 51-57$. 
Loosfelt, H., Atger, M., Misrahi, M., Vu Hai, M.T. and Milgrom, E. (1986) Cloning and sequence analysis of rabbit progesterone receptor cDNA. Proc. Natl. Acad. Sci. USA $\underline{83}$, 9045-9049.

Lubahn, D.B., Joseph, D.R., Sullivan, P.M., Willard, H.F., French, F.S. and Wilson, E.M. (1988A) Cloning of human androgen receptor complementary DNA and localization to the x-chromosome. Science 240, 327-330.

Lubahn, D.B., Joseph, D.R., Sar, M., Tan, J.-A., Higgs, H.N., Larson, R.E., French, F.S. and Wilson, E.M. (1988B) The human androgen receptor: complementary DNA cloning, sequence analysis and gene expression in the prostate. Mol.Endocrinol. 2 , 1265-1275.

Lubahn, D.B., Brown, T.R., Simental, J.A., Higgs, H.N., Migeon, C.J., Wilson, E.M. and French, F.S. (1989) Sequence of the intron/exon junctions of the coding region of the human androgen receptor gene and identification of a point mutation in a family with complete androgen insensitivity. Proc. Natl. Acad. Sci. USA $\underline{86}$, 9534-9538.

Luisi, B., Xu, W., Otwinowski, Z,, Freedman, L., Yamamoto, K. and Sigler, P.B. (1991) Crystallographic analysis of the interaction of the glucocorticoid receptor with DNA. Nature 352, 497-505.

Ma, Z.Q., Santagati, S., Patrone, C., Pollio, G., Vegeto, E. and Maggi, A. (1994) Insulin-like growth factors activate estrogen receptor to control the growth and differentiation of the human neuroblastoma cell line SK-ER3. Mol. Endocrinol. ㅁ, 910-918.

Mainwaring, W.I.P. (1969) The binding of ${ }^{3} \mathrm{H}$-testosterone within nuclei of the rat prostate. J. Endocrinol. 44, 323-333.

Mainwaring, W.I.P. and Peterken, B.M. (1971) A reconstituted cell-free system for the specific transfer of steroid receptor complexes into nuclear chromatin isolated from rat ventral prostate gland. Biochem. J. 125, 285-295.

Maric, S.C., Crozat, A. and Jänne, O. (1992) Structure and organization of the human Sadenosylmethionine decarboxylase gene. J. Biol. Chem. 267, 18915-18923.

Marshall, G.R. and Nieschlag, H. (1987) In: Inhibin Isolation, estimation and Physiology, Vol. 1, (Sheth, A.R., Ed.) pp. 3-15. CRC Press, Boca Raton.

Mason, S.A. and Housley, P.R. (1993) Site-directed mutagenesis of the phosphorylation sites in the mouse glucocorticoid receptor. J. Biol. Chem. 268, 21501-21504.

McNaught, R.W., Dayani, N. and Smith, R.G. (1990) Receptor interconversion model of hormone action I, Biochemistry 29, 2685-2690.

Meek, D.W. and Street, A.J. (1992) Nuclear protein phosphorylation and growth control. Biochem. J. 287, 1-15.

Mendel, D.B., Bodwell, J.E. and Munck, A. (1987) Activation of cytosolic glucocorticoid receptor complexes in intact WEHI-7 cells does not dephosphorylate the steroid binding protein. J. Biol. Chem. 262, 5644-5648.

Menon, M. and Walsh, P.C. (1979) Hormonal therapy for prostatic cancer. In: Murphy, G.P. (ed). Prostatic cancer (Publishing Comp. Inc.) pp. 175-200.

Miesfeld, R., Rusconi, S., Godowski, P.J., Maler, B.A., Okret, S., Wikström, A-C., Gustafsson, J.A. and Yamamoto, K. (1986) Genetic complementation of a glucocorticoid receptor deficiency by expression of cloned receptor cDNA. Cell 46 , 389-399.

Migliaccio, A., Rotondi A. and Auricchio F. (1986) Estradiol receptor: phosphorylation on tyrosine in uterus and interaction with anti-phosphotyrosine antibody. EMBO J. $\underline{5}, 2867-$ 2872. 
Misrahi, M., Atger, M., d'Auriol, L., Loosfelt, H., Meriel, C., Fridlanski, F., GuiochonMantel, A., Galibert, F. and Milgrom, E. (1987) Complete amino acid sequence of the human progesterone receptor deduced from cloned cDNA. Biochem. Biophys. Res. Commun. 143, 740-748.

Mitchell, P.J. and Tjian, R. (1989) Transcriptional regulation in mammalian cells by sequence specific DNA binding proteins. Science 245, 371-378.

Mizokami, A., Yeh, S-Y. and Chang, C. (1994) Identification of a 3',5'-cyclic AMP response element and other cis acting elements in the human androgen receptor gene promoter. Mol.Endocrinol. 8 , 77-88.

Moyer, M.L., Borror, K.C., Bona, B.J., DeFranco, D.B. and Nordeen, S.K. (1993) Modulation of cell signaling pathways can enhance or impair glucocorticoid-induced gene expression without altering the state of receptor phosphorylation. J. Biol. Chem. 268, 22933-22940.

Mulder, E., Foekens, J.A., Peters, M.J. and van der Molen, H.J. (1979) A comparison of heparin-agarose and DNA cellulose for the characterization and partial purification of androgen receptors from rat prostate. FEBS Lett. 97, 260-264.

Mulder, E., Vrij, A.A. and Brinkmann, A.O. (1983) DNA and ribonucleotide binding characteristics of two forms of the androgen receptor from rat prostate. Biochem. Biophys.Res.Commun. 114, 1147-1153.

Mulder, E., Brinkmann, A.O. and de Boer, W. (1985) Characterization and partial purification of different forms of the androgen receptor and their interaction with DNA and RNA. In: Regulation of androgen action. Ed. N. Bruchovsky, A. Chapdelaine, F. Neumann. Congressddruk R. Brickner, Berlin, pp. 141-147.

Mulder, E. and Brinkmann, A.O. (1985) Interaction of androgen receptors with nuclear chromatin. In Interaction of steroid receptors with DNA. Ed. Sluyser. pp. 202-225, EllisHorwood.

Mukhopadhyay, N.K., Price, D.J., Kyriakis, J.M., Pelech, S., Sanghera, J. and Avruch, J. (1992) An array of insulin activated proline-directed serine/threonine protein kinases phosphorylates p70 S6 kinase. J. Biol. Chem. 267, 3325-3335.

Munck, A. and Brinck-Johnsen, T. (1968) Specific and nonspecific physicochemical interactions of glucocorticoids and related steroids with rat thymus cells in vitro. J. Biol. Chem. 243, 5556-5565.

Murtha, P., Tindall, D.J. and Young, C. (1993) Androgen induction of a human prostate specific kallikrein hKLK2 : characterization of an androgen response element in the 5' promoter region of the gene. Biochemistry $32,6459-6464$.

Murthy, L.R., Chang, C.H., Rowley, D.R., Scardino, P.T. and Tindall, H.J. (1984) Phsysicochemical characterization of the androgen receptor from hyperplastic human prostate. Prostate $\underline{5}, 567-579$.

Nakao, M. and Moudgil, V.K. (1989) Hormone specific phosphorylation and transformation of chicken oviduct progesterone receptor. Biochem. Biophys. Res. Commun. 164, $295-$ 303.

Nakao, M., Mizutami, T., Bhakta, A., Ribarac-Stepic, N. and Moudgil, V.K. (1992) Phosphorylation of chicken oviduct progesterone receptor by cAMP dependent protein kinase. Arch.Bioch. Biophys. 298, 340-348.

Nielsen, C.J., Sando, J.J., Vogel, W.M. and Pratt, W.B. (1977A) Glucocorticoid receptor inactivation under cell-free conditions. J. Biol. Chem. 252, 7568-7578.

Nielsen, C.J., Sando, J.J. and Pratt, W.B. (1977B) Evidence that dephosphorylation inactivates glucocorticoid receptors. Proc. Natl. Acad. Sci. USA 74, 1398-1402. 
Northrop, J.P., Gametchu, B., Harrison, R.W. and Ringold, G.M. (1985) Characterization of wild type and mutant glucocorticoid receptors from rat hepatoma and mouse L-cells. J. Biol. Chem. 260, 6398-6403.

Orti, E., Mendel, D.B., Smith, L.I., and Munck, A. (1989) Agonist dependent phosphorylation and nuclear dephosphorylation of glucocorticoid receptors in intact cells. J.Biol.Chem. 264, 9728-9731.

Orti, E., Hu, L-M. and Munck, A. (1993) Kinetics of glucocorticoid receptor phosphorylation in intact cells. J.Biol. Chem. 268, 7779-7784.

Page, M.J. and Parker, M.G. (1982) Effect of androgen on the transcription of rat prostatic binding protein genes. Mol. Cell. Endocrinol. 28, 343-355.

Palvimo, J.J., Kallio, P.J., Ikonen, T., Mehto, M. and Jänne, O.A. (1993) Dominant negative regulation of transactivation by the rat androgen receptor: roles of the $\mathrm{N}$-terminal domain and heterodimer formation. Molec. Endocrinol. 7 , 1399-1407.

Parker, M.G., White, R., Hurst, H., Needham, M. and Tilly, R. (1983) Prostatic steroid binding protein: Isolation and characterization of $\mathrm{C} 3$ genes. J. Biol. Chem. 258, 12-15.

Peeters, B.L., Mous, J.M., Rombauts, W.A. and Heyns, W.J. (1980) Androgen induced messenger RNA in rat ventral prostate. J.Biol. Chem. 255, 7017-7023.

Peeters, B., Heyns, W., Mous, J. and Rombauts, W. (1982) Structural studies on rat prostatic binding protein. Eur. J.Biochem. 123 , 55-62.

Perry, S., Viskochil, D.H., Ho, K.C., Fong, K., Stafford, D.W., Wilson, E.M. and French, F.S. (1985) Androgen receptor binding to the C3(1) subunit gene of rat prostatein. In: Regulation of androgen action. Eds. Bruchovsky, N., Chapdelaine, A. and Neumann, F. Congressdruck Brüickner, Berlin, pp-167-173.

Pike, J.W. and Sleator, N.M. (1985) Hormone dependent phosphorylation of the 1,25dihydroxyvitamin $\mathrm{D}_{3}$ receptor in mouse fibroblasts. Biochem. Biophys. Res. Commun. $131,378-385$.

Poletti, A., Conneely, O.M., McDonnell, D.P., Schrader, W.T., O'Malley, B.W. and Weigel, N.L. (1993) Chicken progesterone receptor expressed in Saccharomyces cerevisiae is correctly phosphorylated at all four Ser-Pro phosphorylation sites. Biochemistry $\underline{32}$, 95639569.

Poletti, A. and Weigel, N.L. (1993) Identification of a hormone dependent phosphorylation site adjacent to the DNA binding domain of the chicken progesterone receptor. Mol. Endocrinol. 7, 241-246.

Pratt, W.B. (1990) Interaction of hsp90 with steroid receptors: organizing some diverse observations and presenting the newest concepts. Mol. Cell. Endocrinol. 74, C69-C76.

Ptashne, M. (1988) How eukaryotic transcriptional activators work. Nature $\underline{335}, 683-689$.

Rataka, B.M. and Samuels, H.H. (1983) The glucocorticoid receptor in GH1 cells: evidence from dense amino acid labeling and whole cell studies for an equilibrium model explaining the influence of hormone on the intracellular distribution of receptor. J. Biol. Chem. 258, 417-425.

Raymoure, W.J., McNaught, R.W., Greene, G.L. and Smith, R.G. (1986) Receptor interconversion model of hormone action. J. Biol. Chem. 261, 17018-17025.

Rejman, J., Landers, J., Goldberger, A., McGormick, D.J., Gosse, B. and Spelsberg, T.C. (1991) Purification of a nuclear protein associated with the chromatin acceptor sites for the avian oviduct progesterone receptor. J. Protein Chemistry 10, 651-667. 
Rennie, P.S., Bowden, J.F., Bruchovsky, N., Frenette, P-S., Foekens, J.A. and Cheng, H. (1987) DNA and protein components of nuclear acceptor sites for androgen receptors in the rat prostate. J. Steroid. Biochem, 27, 513-520.

Rennie, P., Bruchovsky, N., Leco, K., Sheppard, P., McQueen, S., Cheng, H., Snoek, R., Hamel, A., Bock, M., McDonald, B., Nickel, B., Chang, C., Liao, S., Cattini, P. and Matusik, R. (1993) Characterization of two cis-acting DNA elements involved in the androgen regulation of the probasin gene. Mol. Endocrinol. 7, 23-36.

Resko, J.A., Goy, R.W. and Phoenix, C.H. (1967) Uptake and distribution of exogenous testosterone in neural and genital tissues of the castrate guinea pig. Endocrinology $\underline{80}$, 490-498.

Riegman, P., Vlietstra, R., van der Korput, J., Brinkmann, A.O. and Trapman, J. (1991A) The promoter of the prostate specific antigen gene contains a functional androgen responsive element. Mol. Endocrinol. 5, 1921-1930.

Riegman, P., Vlietstra, R., van der Korput, J., Romijn, J. and Trapman, J. (1991B) Identification and androgen regulated expression of two major human glandular kallikrein-1 (hGK-1) mRNA species. Mol. Cell. Endocrinol. 76, 181-190.

Ris-Stalpers, C., Hoogenboezem, T., Sleddens, H., Verleun-Mooijman, M., Degenhart, H., Drop, S., Halley, D., Oosterwijk, J., Hodgins, M., Trapman, J. and Brinkmann, A.O. (1994) A practical approach to the detection of androgen receptor gene mutations and pedigree analysis in families with $\mathrm{X}$-linked androgen insensitivity. Pediatr. Res. 36, 227 . 234.

Robbins, J., Dilworth, S.M., Laskey, R.A. and Dingwall, C. (1991) Two interdependent basic domains in nucleoplasmin nuclear targeting sequence: identification of a class of 18 bipartite nuclear targeting sequences. Cell $64,615-623$.

Roberts, K.P. and Zirkin, B.R. (1991) Androgen regulation of spermatogenesis. Ann. N.Y. Acad. Sci. 637, 90-106.

Roche, P.J., Hoare, S.A. and Parker, M.G. (1992) A consensus DNA binding site for the androgen receptor. Mol. Endocrinol. 6, 2229-2235.

Rossini, G.P. and Liao, S. (1982) Intracellular inactivation, reactivation and dynamic status of prostate androgen receptors. Biochem. J. 208, 383-392.

Rossini, G.P. (1984) Steroid receptor recycling and its possible role in the modulation of steroid hormone action. J. Theor. Biol. 108, 39-53.

Rowley, D.R., Chang, C.H. and Tindall, D.J. (1984) Effect of sodium molybdate on the androgen receptor from the R3327 prostatic tumor. Endocrinology 114, 1776-1783.

Ruizeveld de Winter, J.A., Trapman, J., Vermey, M., Mulder, E., Zegers, N. and van der Kwast, Th.H. (1991) Androgen receptor expression in human tissues: an immunohistochemical study. J. Histochem. Cytochem. 39, 927-936.

Rundlett, S.E., Wu, X.-P, and Miesfeld, R.L. (1990) Functional characterization of the androgen receptor confirms that the molecular basis for androgen action is transcription regulation. Mol. Endocrinol. 4, 708-714.

Rushmere, N.K., Parker, M.G. and Davies, P. (1987) Androgen receptor-binding regions of an androgen-responsive gene. Mol. Cell. Endocrinol. 51, 259-265.

Sar, M., Liao, S. and Stumpf, W.E. (1970) Nuclear concentration of androgen in rat seminal vesicles and prostate demonstrated by dry-mount autoradiography. Endocrinology 86 , 1008-1011.

Schwabe, J., Neuhaus, D. and Rhodes, D. (1990) Solution structure of the DNA binding domain of the oestrogen receptor. Nature $\underline{348}, 458-461$. 
Schwabe, J.W.R. and Rhodes, D. (1991) Beyond zinc fingers: steroid hormone receptors have a novel structural motif for DNA recognition. Trends Biochem. Sci. 16, 291-296.

Schwabe, J., Chapman, L., Finch, J.T. and Rhodes, D. (1993) The crystal structure of the estrogen receptor DNA-binding domain bound to DNA: how receptors discriminate between their response elements. Cell 75, 567-578.

Shan, L-X., Rodriguez, M.C. and Jänne, O.A. (1990) Regulation of androgen receptor protein and mRNA concentrations by androgens in rat ventral prostate and seminal vesicles and in human hepatoma cells. Mol. Endocrinol. $\underline{4}$, 1636-1646.

Sheridan, P.L., Krett, N.L., Gordon, J.A. and Horwitz, K.B. (1988) Human progesterone receptor transformation and nuclear down-regulation are independent of phosphorylation. Mol.Endocrinol. 2, 1329-1342.

Sheridan, P.L., Evans, R.M. and Horwitz, K.B. (1989A) Phosphotryptic peptide analysis of human progesterone receptors. J. Biol. Chem. 264, 6520-6528.

Sheridan, P.L., Francis, M.D. and Horwitz, K.B. (1989B) Synthesis of human progesterone receptors in T47D cells. J.Biol.Chem. 264, 7054-7058.

Sheridan, P.J. (1991) Can a single androgen receptor fill the bill? Mol. Cell. Endocrinol. 76 , C39-C45.

Simental, J.A., Sar, M., Lane, M.V., French, F.S. and Wilson, E.M. (1991) Transcriptional activation and nuclear targeting signals of the human androgen receptor. J. Biol. Chem. 266, 510-518.

Singh, V.B. and Moudgil, V.K (1985) Phosphorylation of rat liver glucocorticoid receptor. J. Biol, Chem. 260, 3684-3690.

Singh, V.B., Eliezer, N. and Moudgil, V.K. (1986) Transformation and phosphorylation of purified molybdate-stabilized chicken oviduct progesterone receptor. Biochim. Biophys. Acta $888,237-248$.

Sleddens, H., Oostra, B.A., Brinkmann, A.O. and Trapman, J. (1992) Trinucleotide repeat polymorphism in the androgen receptor gene. Nucl. Acids Res $20,1427$.

Smith, D.F. and Toft, D.O. (1993) Steroid receptors and their associated proteins. Mol. Endocrinol. 7, 4-11.

Smith, L.I., Mendel, D.B., Bodwell, J.E. and Munck A. (1989) Phosphorylated sites within the functional domains of the $100 \mathrm{kDa}$ steroid binding subunit of gltucocorticoid receptors. Biochemistry $\underline{28}, 4490-4498$.

Somers, J.P. and DeFranco, D.B. (1992) Effects of okadaic acid, a protein phosphatase inhibitor on glucocorticoid receptor-mediated enhancement. Mol. Endocrinol. $\underline{6}, 26-34$.

Spelsberg, T.C., Goldberger, A., Horton, M. and Hora, J. (1987) Nuclear acceptor sites for sex steroid hormone receptors in chromatin. J. Steroid Biochem. 27, 133-147.

Stamatiadis, D., Portois, M.C., Blondeau, J.P., Mowzowicz, I. and Mauvais-Jarvis, P. (1987) Photoaffinity labelling of the androgen receptor from human skin fibroblasts. Mol. Cell. Endocrinol. 54, 141-149.

Stavenhagen, J.B. and Robins, D.M. (1988) An ancient provirus has imposed androgen regulation on the adjacent mouse sex-limited protein gene. Cell 55 , 247-254.

Strähle, U., Klock, G. and Schiitz, G. (1987) A DNA sequence of 15 base pairs is sufficient to mediate both glucocorticoid and progesterone induction of gene expression. Proc. Natl. Acad. Sci. USA 84, 7871-7875.

Sullivan, W.P., Smith, D.F., Beito, T.G, Krco, C.J. and Toft, D.O. (1988A) Hormone dependent processing of the avian progesterone receptor. J. Cell. Biochem. $\underline{36}$, 103-119. 
Sullivan, W.P., Madden, B.J., McCormick, D.J. and Toft, D.O. (1988B) Hormone dependent phosphorylation of the avian progesterone receptor. J. Biol. Chem. 263, 14717-14723.

Takimoto, G.S., Tasset, D.M., Eppert, A.C. and Horwitz, K.B.(1991) Transcription is regulated by phosphorylation of human progesterone receptor following DNA binding. Ann.meeting Endocrin. Society; Abstract 309.

Takimoto, G.S., Tasset, D.M., Eppert, A.C. and Horwitz, K.B.(1992) Hormone-induced progesterone receptor phosphorylation consists of sequential DNA-independent and DNA -dependent stages: analysis with zinc finger mutants and the progesterone antagonist ZK-98299. Proc. Natl. Acad. Sci. USA, 89, 3050-3054.

Takimoto, G.S. and Horwitz, K.B. (1993) Progesterone receptor phosphorylation. Trends Endocrinol, Metab. $4,1-7$.

Tan, J.A., Joseph, D.R., Quarmby, V.E., Lubahn, D.B., Sar, M., French, F.S. and Wilson, E.M. (1988) The rat androgen receptor: primary structure, autoregulation of its messenger ribonucleic acid, and immunocytochemical localization. Mol.Endocrinol, 2, 1276-1285.

Tan, J., Marschke, K.B., Ho, K-C., Perry, S.T., Wilson, E.M. and French, F.S. (1992) Response elements of the androgen related C3 gene. J. Biol. Chem. 267, 4456-4466.

Tienrungroj, W., Sanchez, E.R., Housley, R., Harrison, R.W. and Pratt, W.B. (1987) Glucocorticoid receptor phosphorylation, transformation and DNA binding. J. Biol. Chem. 262, 17342-17349.

Tilley, W.D., Marcelli, M., Wilson, J.D. and McPhaul, M.J. (1989) Characterization and expression of a cDNA encoding the human androgen receptor. Proc. Natl. Acad. Sci. USA $\underline{86}, 327-331$.

Tilley, W.D., Marcelli, M. and McPhaul, M.J. (1990) Expression of the human androgen receptor gene utilizes a common promotor in diverse human tissues and cell lines. J. Biol. Chem. 265, 13776-13781.

Tindall, D.J., Chang, C-H, Lobl, T.J, and Rowley, D.R. (1984) Molecular properties of the androgen receptor in rat ventral prostate. Ann. N. Y. Acad. Sci. 438, 39-53.

Trapman, J., Klaassen, P., Kuiper, G., van der Korput, J., Faber, P., van Rooij, H., Geurts van Kessel, A., Voorhorst, M., Mulder, E. and Brinkmann, A.O. (1988) Cloning, structure and expression of a cDNA encoding the human androgen receptor. Biochem. Biophys. Res. Commun. 153, 241-248.

Truss, M., Chalepakis, G., Pina, B., Barrettino, D., Bruggemeier, U., Kalff, M., Slater, E. and Beato, M. (1992) Transcriptional control by steroid hormones. J. Steroid Biochem. Molec. Biol. $41,241-248$.

Umesono, K. and Evans, R.M. (1989) Determinants of target gene specificity for steroid/thyroid hormone receptors. Cell 57, 1139-1146.

van Dijck, P., Winderickx, J., Heyns, W. and Verhoeven, G. (1989) Binding of androgen receptor complexes to $\alpha 2 \mu$-globulin genes and to the long terminal repeat of mouse mammary tumour virus. Mol. Cell. Endocrinol. 64, 195-214.

van der Kwast, Th.H., Schalken, J., Ruizeveld de Winter, J.A., van Vroonhoven, C., Mulder, E., Boersma, W. and Trapman, J. (1991) Androgen receptors in endocrine therapy resistant human prostate cancer. Int. J. Cancer 48, 189-193.

van Laar, J.H., Voorhorst-Ogink, M., Zegers, N., Boersma, W., Claassen, E., van der Korput, J., Ruizeveld de Winter, J., van der Kwast, Th., Mulder, E., Trapman, J. and Brinkmann, A.O. (1989) Characterization of polyclonal antibodies against the $\mathrm{N}$-terminal domain of the human androgen receptor. Mol.Cell.Endocrinol. 67, 29-38. 
van Laar, J., Bolt-de Vries, J., Zegers, N., Trapman, J. and Brinkmann, A.O. (1990) Androgen receptor heterogeneity and phosphorylation in human LNCaP cells. Biochem. Biophys. Res. Commun. 166, 193-200.

van Laar, J., Berrevoets, C., Trapman, J., Zegers, N. and Brinkmann, A.O. (1991) Hormone dependent androgen receptor phosphorylation is accompanied by receptor transformation in LNCaP cells. J. Biol. Chem. 266, 3734-3738.

van Leeuwen, J.P.T.M., Birkenhäger, J.C., van den Bemd, G.J.C.M., Buurman, C.J., Staal, A., Bos, M.P. and Pols, H.A.P. (1992) Evidence for the functional involvement of protein kinase $\mathrm{C}$ in the action of 1,25-dihydroxyvitamin D3 in bone. J. Biol. Chem. 267, 1256212569.

van Loon, D., Voorhorst, M.M., Brinkmann, A.O. and Mulder, E. (1988) Purification of the intact $110 \mathrm{kDa}$ form of the androgen receptor from calf uterus to near homogeneity. Biochim. Biophys. Acta 970, 278-286.

van der Weyden Benjamin, W.S., Hendry, W.J. and Harrison, R.W. (1990) The mouse glucocorticoid receptor DNA-binding domain is not phosphorylated in vivo. Biochem. Biophys. Res. Commun. 166, 931-936.

Veldscholte, J., Berrevoets, C.A., Brinkmann, A.O., Grootegoed, J.A. and Mulder, E. (1992A) Antiandrogens and the mutated androgen receptor of LNCaP cells: differential effects on binding affinity, heat-shock protein interaction, and transcription activation. Biochemistry 31, 2393-2399.

Veldscholte, J., Berrevoets, C.A., Zegers, N.D., van der Kwast, Th.H., Grootegoed, J.A. and Mulder, E. (1992B) Hormone-induced dissociation of the androgen receptor heat-shock protein complex: use of a new monoclonal antibody to distinguish transformed from nontransformed receptors. Biochemistry $\underline{31}, 7422-7430$.

Virkkunen, P., Hedberg, P., Palvimo, J., Birr, E., Porvari, K., Ruokonen, M., Taavitsainen, P., Jänne, O. and Vihko, P. (1994) Structural comparison of human and rat prostate specific acid phosphatase genes and their promoters. Biochem.Biophys.Res.Commun. $\underline{202}, 49-57$.

Viskochil, D.H., Perry, S.T., Lea, O., Stafford, D.W., Wilson, E.M. and French, F.S. (1983) Isolation of two genomic sequences encoding the 14000 dalton subunit of rat prostatein. J. Biol. Chem. 258, 8861-8866.

Vulliet, P.R., Hall, F.L., Mitchell, J.P. and Hardie, D.G. (1989) Identification of a novel proline directed serine/theonine protein kinase in rat pheochromocytoma. J. Biol. Chem. 264, 16292-16298.

Washburn, T., Hocutt, A., Brautigan, D.L. and Korach, K.S. (1991) Uterine estrogen receptor in vivo: phosphorylation of nuclear specific forms on serine residues. Mol. Endocrinol. S, 235-242.

Wei, L.L., Sheridan, P.L., Krett, N.L., Francis, M.D., Toft, D.O., Edwards, D.P. and Horwitz, K.B. (1987) Immunologic analysis of human breast cancer progesterone receptors. Structure, phosphorylation and processing. Biochemistry 26, 6262-6272.

Weigel, N.L., Tash, J.S., Means, A.R., Schrader, W.T, and O'Malley B.W. (1981) Phosphorylation of hen progesterone receptor by cAMP dependent protein kinase. Biochem. Biophys. Res. Commun. 102, 513-519.

Weigel, N.L., Carter, T.H., Schrader, W.T. and O'Malley B.W. (1992) Chicken progesterone receptor is phosphorylated by a DNA-dependent protein kinase during in vitro transcription assays. Mol. Endocrinol. $\underline{6}, 8-14$. 
Wikström, A-C., Bakke, O., Okret, S., Bronnegård, M. and Gustafsson, J.A. (1987) Intracellular localization of glucocorticoid receptors: evidence for cytoplasmic and nuclear localization. Endocrinology $\underline{120}, 1232-1242$.

Wilbert, D.M., Griffin, J.E. and Wilson, J.D. (1983) Characterization of the cytosol androgen receptor of the human prostate. J. Clin. Endocrinol. Metab. 56, 113-120.

Wilson, E.M. Wright, B.T. and Yarbrough, W.G. (1986) The possible role of disulphide bond reduction in transformation of the 10S androgen receptor. J. Biol. Chem. 261, 6501-6508.

Wilson, E.M., Simental, J.A, French, F.S. and Sar, M. (1991) Molecular analysis of the androgen receptor, Ann. N.Y. Acad. Sci. 637, 56-63.

Wolf, D.A., Schulz, P. and Fitller, F. (1992) Transcriptional regulation of prostate kallikrein -like genes by androgen. Mol. Endocrinol, $\underline{6}$, 753-762.

Wong, C., Zhou, Z.-X., Sar, M. and Wilson, E.M. (1993) Steroid requirement for androgen receptor dimerization and DNA binding. J. Biol. Chem. 268, 19004-19012.

Yamamoto, K.R. (1985) Steroid receptor regulated transcription of specific genes and gene networks. Annu. Rev. Genet. 19, 209-252.

Yan-Bo Xie, Ya-Ping Sui, Li-Xin Shan, Palvimo, J., Phillips, D. and Jänne, O. (1992) Expression of androgen receptor in insect cells. J. Biol. Chem. 267, 4939-4948.

Young, C.Y.F., Murthy, L.R., Prescott, J.L. and Tindall, D.J. (1988) Monoclonal antibodies against the androgen receptor: recognition of human and other mammalian androgen receptors. Endocrinology $\underline{123}$, 601-610.

Young, C., Qiu, S., Prescott, J.L. and Tindall, D.J. (1990) Overexpression of a partial human androgen receptor in $\mathrm{E}$. Coli, characterization of steroid binding, DNA binding, and immunological properties. Mol. Endocrinol. 4, 1841-1849.

Zegers, N.D., Claassen, E., Neelen, C., Mulder, E., van Laar, J.H., Voorhorst, M., Berrevoets, C.A., Brinkmann, A.O., van der Kwast, Th.H., Ruizeveld de Winter, J.A., Trapman, J. and Boersma, W.J.A. (1991) Epitope prediction and confirmation for the human androgen receptor: generation of monoclonal antibodies for multi-assay performance following the synthetic peptide strategy. Biochim. Biophys. Acta 1073, 23-32.

Zhang, Y., Bai, W., Allgood, V.E. and Weigel, N.L. (1994) Multiple signaling pathways activate the chicken progesterone receptor. Mol. Endocrinol. $\underline{8}, 577-584$.

Zhou, Z.X., Simental, J.A., Scott, R.S., Jensen, P.D. and Wilson, E.M. (1991) The amino terminal transcriptional activation domain of the human androgen receptor. Annual Meeting Endocrin.Society; Abstract 250.

Zhou, Z.X., Wong, C., Sar, M. and Wilson, E.M. (1994A). The androgen receptor: an overview. Rec. Progr. Horm. Res. 49, 249-274.

Zhou, Z.-X., Sar, M., Simental, J., Lane, M. and Wilson, E.M. (1994B) A ligand dependent bipartite nuclear targeting signal in the human androgen receptor. J. Biol. Chem. 269, 13115-13123.

Zoppi, S., Wilson, C., Harbison, M., Griffin, J., Wilson, J., McPhaul, M. and Marcelli, M. (1993) Complete testicular feminization caused by an amino terminal truncation of the androgen receptor with downstream initiation. J. Clin. Invest. $\underline{91}$, 1105-1112. 



\section{CHAPTER 3}

\section{SYNTHESIS AND POST-TRANSLATIONAL MODIFICATION OF THE ANDROGEN RECEPTOR IN LNCaP CELLS}

George G.J.M. Kuiper, Petra E. de Ruiter, J. Anton Grootegoed and Albert O. Brinkmann

Mol. Cell. Endocrinol. (1991), 80, 65-73. 


\title{
Synthesis and post-translational modification of the androgen receptor in LNCaP cells
}

\author{
George G.J.M. Kuiper, Petra E. de Ruiter, J. Anton Grootegoed \\ and Albert O. Brinkmann \\ Department of Entocrinology and Reproduction, Afedical Faculty, Erasmus Unicersity Rotterdam, 3000 DR Rolterdam, \\ The Netherlands \\ (Received 17 Aprił 1991; accepted 16 May 1991)
}

Nigy work: Prostate tunnor cell; Sternid receptor; Androgen post-translational modification

\section{Summary}

Androgen receptor synthesis and modification were studied in the human LNCaP cell line. Immunoblotting with a specific polyclonal antibody showed that the androgen receptor migrated as a closely spaced 110-112 kDa doublet on sodium dodecyl sulfate-polyacrylamide gel electrophoresis (SDS-PAGE) gels. Most of the receptor protein is present in the higher molecular mass form. Pulse labelling experiments with $\left[{ }^{35} \mathrm{~S}\right]$ methionine showed that the androgen receptor is synthesized as a single $110 \mathrm{kDa}$ protein which is rapidly converted to a $112 \mathrm{kDa}$ protein. Alkaline phosphatase treatment of cytosols from $\left[{ }^{35}\right.$ S $]$ methionine pulse labelled cells catsed a gradual elimination of the $112 \mathrm{kDa}$ isoform with a concomitant increase of the $110 \mathrm{kDa}$ isoform. This indicates that the observed 110 to $112 \mathrm{kDa}$ upshift of the newly synthesized androgen receptor reflects receptor phosphorylation. Both isoforms can bind hormone and can undergo a hormone dependent transformation to a tight nuclear binding form, indicating that the 110 to $112 \mathrm{kDa}$ conversion is not an obligatory step for homone binding or receptor transformation.

Address for correspondence: (i. Kuiper, Department of Endocrinology and Reproduction, Medical Faculty, Erasmus University Rotterdam, P.O. Box 1738, 3000 DR Rntterdam, The Netherlands. Tel. (B[01-4087338; Fax $010.4,36,8,32$.

It should be noteo that the lerm 'Iransformation' will be used to descrihe the process whereby the stesoid-bound receplor is conserted from a non-DNA-hinding state to a tight nuclear binding form. The term 'seceptor activation' describes the acculisition of the sleroid binditıg slate.

\section{Introduction}

Steroid hormone receptors are transacting gene regulating proteins, involved in the effectuation of steroid hormone induced cellular responses. Upon binding of hormone to its specific receptor, the receptor-hormone complex is known to undergo a conformational change called transformation, which is thought to precede binding of 
the complex to hormone resnonsive elements in the target cell genome (Evans, 1988; Beato, 1989). Stcroid hormone receptors are part of a dynanic system. The receptors are synthesized and degraded to maintain a steady state level in hormone untreated celts, and are up- or downregulated in hormone treated cells (Horwitz et al., 1982; McDonnell et al., 1987; Blok et al., 1989; Tilley ef al, 1990). In general cellular hormone sensitivity might not only depend on changes in protein turnover rates, but also on covalent modifications that activate receptors to hormone binding stites. The exact molecular detiils of the processes of hormonc binding and receptor transformation are still unclear.

Ample evidence has been provided that steroid hormone receptors can exist as phosphoproteins it intact cells (Dougherty et al, 1984; Migliaccio et al., 1986; Sheridan et al., 1988; van Laar et al., 1990). Phosphorylation appears to be required for activation of estrogen receptors to a hormone binding state (Migliaccio et al., 1986). The receptors for progesterone, glucocorticoids and andro. gens are also phosphoproteins, but the function of this modification is presently unknown.

With the recent production of specific antibodjes against the androgen receptor, tools were provided for more detailed analysis of the andro. gen receptor protein (van Laar et al., 1989; Quarmby et al., 1990). Using photoaffinity la+ belling and inmunoblotling, it has been observed that the androgen receptor from LNCaP cells migrates as a closely spaced doublet of $110-112$ $k$ Da on sodiun dodecyl sulfatc-polyacrylamide gel electroploresis (SDS-PAGE). Furthernore, evidence has been obtained that the LNCal' cell androgen receptor is a phospltoprotein and that phosplorylation is stimulated by homone (van Laar et al, 1990, 1991). The $110-112 \mathrm{kDa}$ proteins might represent androgen receptor isoforms, possibly produced througl various types of modification mechanisus, inchuding phosphorylation. Plosphorylation and/or other covalent modifications of the androgen receptor protein might occur co-translationally, but it is also possible that a significant time lag could exist between synthesis and modification. In fact, apart from a co/post-translational ligand independent phosphorylation the androgen receptor does undergo ligand stimulated hyperphosphorylation (van Laar et at., 1991).

The present results obtained by $\left[{ }^{35}\right.$ S $]$ methionine incorporation and immunoprecipitation, slow that the LNCaP cell androgen receptor is synthesized as a single $110 \mathrm{kDa}$ protein which is rapidly converted into a forn with a molecular mass of $112 \mathrm{kDa}$. It was also found that the conversion of the newly synthesized receptor reflects pirosphorylation and is not of necessity for the acquisition of the hormone binding state and receptor transformation to the tight nuclcar binding form.

\section{Materials and methods}

\section{Materials}

Radioactive methionine $\left(\left[{ }^{35} \mathrm{~S}\right]\right.$ methionine, spec. act. $>800 \mathrm{Ci} / \mathrm{mmol}$ ) was obtained from Amersham (Little Chalfont, U.K.). Culture media were obtained from Seromed (Berijn, F.R.G.). Fetal calf serum was obtained from Seralab (U.K). The

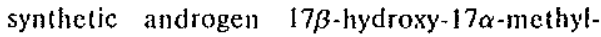
4,9,11-estratrien-3-one (R1881) was obtained from NEN (Boston, MA, U.S.A.). All other chemicals and reagents were purchased from either Sigma Chemical Co. (St. Louis, MO, U.S.A.) or Merck (Darmstadt, F.R.G.). Plosphorylase $b$ and $\beta$ galactosidase were obtained from BoehringerMannicim (Penzburg, F.R.G.), and labelled with $\left[{ }^{14} \mathrm{C}\right\}$ formaldehyde as described (Jentoft et al., 1979).

\section{Cell culture}

The LNCaP cell tine (derived from a fast growing colony of a Lymph Node Carcinoma of the Prostate) was a gift from Dr. Horoszewicz (Horoszewicz ef al., 1983). The cells were cultured in plastic tissue culture flasks in RPMI 1640 culture medium, with added glutanine, streptomycin, penicillin and 7.5\% (v/v) heat-inactivated $\left(56^{\circ} \mathrm{C}\right)$ fetal calf serum, at $37^{\circ} \mathrm{C}$ in a humidified atmosphere of $5 \% \mathrm{CO}_{2}$ in air. Two to four days before an experiment, medium was replaced by the same medium, but containing $5 \%$ $(v / v)$ heat inactivated charcoal treated fetal call serum. LNCaP cells between the 65 th and $72 \mathrm{th}$ passage in vitro were used. 
Mrtabolic labolling with / ${ }^{35}$ S/methionime

For labeling stuclies, $10^{7}$ LNCaP cells were pre-incubated for 1 h at $37^{\circ} \mathrm{C}$ with methionine free RPMI 1640 medium. Subsequently, $\left[{ }^{35} \mathrm{~S}\right]$ methionine was added to a concentration of approximately $20 \mu \mathrm{Ci} / \mathrm{ml}$ and the incubations were conlinued for different time periods at $37^{\circ} \mathrm{C}$. For pulse-chase experiments, medium was removed after $30 \mathrm{~min}$, the cells were washed once with phosphate buffered saline (PBS), and the incubations were continued in RPMI 1640 with $0.5 \mathrm{mM}$ methionine. Incubations were stopped by removal of the medium immediately followed by a wash with PBS at $20^{\circ} \mathrm{C}$.

Subsequently, the cells were lysed in buffer A (40 mM Tris- $\mathrm{mCl} \mathrm{pH} 7.4,1 \mathrm{mM}$ EDTA, $10 \%$ $(v / v)$ glycerol, $10 \mathrm{mM}$ dithiothreitol, $10 \mathrm{mM}$ $\mathrm{Na}_{2} \mathrm{MoO}_{4}, 50 \mathrm{mM} \mathrm{Nali)}$, supplemented with $1 \%$ $(v / v)$ Triton $X-100,0.5 \%(w / v)$ sodium deoxycholate, $0.08 \%$ (w/v) SDS, $0.6 \mathrm{mM}$ phenylmethylsulfonyl fluoride (PMSF) and $0.5 \mathrm{mM}$ bacitracin at $4^{\circ} \mathrm{C}$. The lysate was centrifuged (10 min, 2000 $\times g)$ and androgen receptor was immunoprecipitated from the supernatant.

\section{Proparation of cylosol and muclear exiract}

Approximately $6 \times 10^{7}$ cells were collected in 5 $\mathrm{ml}$ of buffer A supplemented with 0.6 mM PMSF, $0.5 \mathrm{mM}$ bacitracine and $0.2 \mathrm{mg} / \mathrm{ml}$ leupeptin. Cells were homogenized and the homogenate was centrifuged for $10 \mathrm{~min}$ at $800 \times \mathrm{g}$. The cytosol was prepared by centrifugation of the supernatant at $105,000 \times g$ for $30 \mathrm{~min}$ at $4^{\circ} \mathrm{C}$. The nuclear pellet was washed with buffer A containing $0.2 \%(v / v)$ Triton $X-100$, and then with buffer $A$ without additions. Subsequently, the nuclear pellet was extracted with buffer A (pH 8.5) containing $0.4 \mathrm{M} \mathrm{NaCl}$ for 1 h at $4^{\circ} \mathrm{C}$. The sample was contrifuged at $105,(0)(0) \times g$ for $30 \mathrm{~min}$.

\section{Immunoprecipitation}

Immunoprecipitation was performed using mouse monoclonal antibody, raised against a synthetic peptide corresponding to the amino acid residues 301-320 of the human androgen receptor (van Laar et al., 1989). I $\mu$ l of ascites, containing either momoclonal androgen receptor anlibody or a non-specific mouse $\operatorname{lgC}$, was mixed with $25 \mu 1$ antimouse $\mathrm{IgG}$ agarose (packed ged)
(Sigma) and $200 \mu 1$ PBS containing $1 \%$ bovine serum albumin (BSA), The mixture was incubated for $2 h$ at $4^{\circ} \mathrm{C}$ using end-over-end rotation, Following centrifugation $(20 \mathrm{~s}, 8000 \times g)$, the supermatant was removed and the agarose beads were washed 3 times with buffer $A$.

The cell lysate, cytosol or nuclear extract was added to the agarose beads, and the mixture was incubated for $2 \mathrm{~h}$ at $4^{\circ} \mathrm{C}$. After centrifugation for $20 \mathrm{~s}$ at $8000 \times g$ the pellets were washed 3 times with buffer $A$, containing $1 \%(\mathrm{v} / \mathrm{v})$ Triton $X+100$, $0.5 \%(\mathrm{w} / \mathrm{v})$ sodium deoxycholate and $0.08 \%$ $(w / v)$ SDS, 3 times with buffer $A$ in the presence of $0.2 \%(v / v)$ Triton $X-100$ and $0.4 \mathrm{M} \mathrm{NaCl}$ and 3 times with buffer $A$ only.

\section{Electrophoresis, bloting and autoradiography'}

After washing of the immunoprecipilates, proteins were extracted with $50 \mu \mathrm{l}$ sample bulfer $(40$ $\mathrm{mM}$ Tris-1HCl pll $6.8,5 \%(\mathrm{v} / \mathrm{v})$ glycerol, $2 \%$ $(\mathrm{w} / \mathrm{v})$ SDS, $10 \mathrm{mM}$ dithiothreitol (DTT), 0.2\% (w/v) bromophend blue), boiled for $2 \mathrm{~min}$ and centrifuged $(5000 \times g, 2 \mathrm{~min})$. The supcrnatants were separated on $7 \%$ SDS-PAGE gels in the mini Protcan Il cell (Bio-Rad) according to the manufacturer's instructions. As marker proteins $\left[{ }^{14} \mathrm{C}\right] \beta$-galactosidase $(116 \mathrm{kDa})$ and $\left[{ }^{14} \mathrm{C}\right]$ phosphorylase $b(97 \mathrm{kDa})$ were used. After electrophoresis the gels were positioned on nitrocellulose paper (Schleicher \& Schüll (Dassel, F.R.G.), $0.45 \mu \mathrm{m}$ ) and placed in a Bio-Rad mini Trans-Blot cell filled with bulfer (16.5 mM Tris, pH $8.3,150 \mathrm{~nm}$ glycine and $20 \% \mathrm{v} / \mathrm{v}$ methanol). The transfer was performed for $60 \mathrm{~min}$ at $100 \mathrm{~V}$. After blotting the paper was incubated with an androgen receptor specific polyclonal rabbit antiserum (SpO61) (van Laar et al., 1989), diluted I: 1000 in PBS $/ 0.05 \%(v / v)$ Tween 20 (PBSTween) for $1 \mathrm{~h}$ at room temperature, washed 2 times for 10 min each with PBS-Tween, and incubated subsequently with alkaline phosphatase-conjugated goat antirabbit $\operatorname{lgG}$ (Sigma) diluted 1:1000 in PBS-Tween. After washing (2 times), the antibody complexes were visualized with a solution of $0.3 \%(w / v) 4$-aminodiphenytamine diazonium sulphate (Sigma) and $0.1 \%$ $(w / v)$ raphthol AS-MX phosphate (Sigma) in 0.2 $M$ Tris- $\mathrm{HCl}, \mathrm{pH} 9.1,10 \mathrm{mM} \mathrm{MgCl}_{2}$. Subsequently, the filter was air-dricd and exposed to 
Hyperfiln $\beta$ max (Amersham) at room tempera. ture.

\section{Receptor dephosphorylation}

After labelling for 30 min with $\left[{ }^{35} \mathrm{~S}\right]$ methionine cells were suspended in TGD bulfer $(40 \mathrm{mM}$ Tris $-\mathrm{HCl}, \mathrm{pH}=8.5,10 \% \mathrm{v} / \mathrm{v}$ glycerol and $1 \mathrm{mM}$ DTT) plus a mixture of protease inhibitors (sec under Preparation of cytosol). Cells were homogenized and centrifuged $(30 \mathrm{~min}, 30,000 \times \mathrm{g})$ to obtain a cytosol. Cytosols $(200 \mu \mathrm{l}$, protein conc. $=$ $10 \mathrm{mg} / \mathrm{ml}$ ) were incubated for 60 min at $37^{\circ} \mathrm{C}$ with no additions, with 100 or 200 units of calf alkatine phosphatase (Boehringer-Mannheim) or with alkaline phosphatase plus the phosphatase inthibitors $10 \mathrm{mM}$ EDTA and $10 \mathrm{mM} \mathrm{NaH}{ }_{2} \mathrm{PO}_{4}$. The samples were then placed on ice, diluted with buffer A (10 mM EDTA) and immunoprecipitated as described.

\section{Results}

Androgen receptor immunobloning and mulse labelling

Immunoprecipitation with a monoclonal androgen receptor antibody and subsequent SDSPAGE showed that the androgen receptor in LNC.iP cells migrates as a closely spaced $110-112$ $\mathrm{kDa}$ doublet (Fig. 1 $\mathrm{A}$ ), Most of the receptor protein was present in the higher molecular mass form according to the difference in intensity between the two bands. The androgen receptor isoforms were olsserved in the presence as well as in the absence of ligand, their relative amounts were constant and both proteins bound hormone as shown by photoaffinity labelling (sec also van Laar et ał., 1990).

In order to investigate the de novo synthesis of the two bands, LNCaP cells were incubated for various time periods with $\left[{ }^{35} \mathrm{~S}\right]$ methionine. In Fig. $I B$, it is shown that, after incubation of hormone depleted LNCaP cells with radiolabelled methionine for $30 \mathrm{~min}$, the amount of methionine incorporated into both isoforms was virtually the same. Upon prolonged incubation, however, a marked increase of the relative labelling intensity of the slower migrating isoform (112 kDa) was observed. The incorporation of $\left[{ }^{35} \mathrm{~S}\right]$ methionine in trichloroacetic acid (TCA) precipititble protein as well
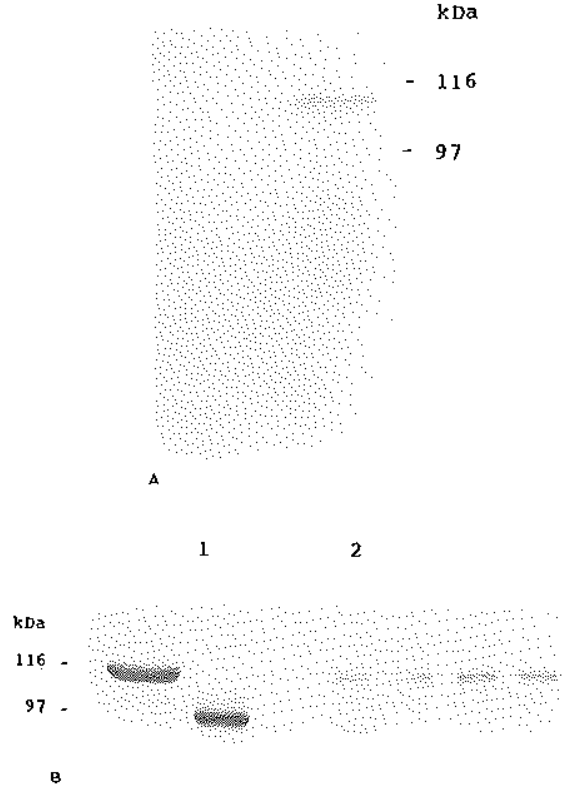

Wh mark 1 34

Fig. 1. A: Inmunoblot of androgen receptor immunopurified from cell is'sates of $\mathrm{L}, \mathrm{NC} 3 \mathrm{P}$ cells. Androgen teceptor was immunoprccipitated using a specific antibody (lane 2) or non. specific mouse $\operatorname{lgG}$ (lane 1) and subjected to SDS.PAGE and blotting. $B$ : "s-Labelling of androgen receptor in LNCaP cells. LNCaP cells, pre-jucubated for 60 min in methionine. free medium, were incubated for different time periods with [ "S Smethionine. Subsequently, androgen receptor was im. mumoprecipitated from total cell lysates and analyzed by SDS-PACF: and blotting. Incubation with [ ${ }^{35}$ S]methionine was for: 30 min (lane 1), 60 min (lane 2), 90 nin (lane 3) and 120 пін (lane 4).

as in androgen receptor protein increased linearly with timc, reaching an optimum between 60 and 90 min after the start of the pulse labelling with $\left[{ }^{35} \mathrm{~S}\right.$ ]methionine (results not shown).

To investigate the apparent upshift in more detail, we performed a time study in which $\left[{ }^{35}\right.$ S]methionine incorporation into the androgen receptor of hormone depleted $\mathrm{LNCaP}$ cells was investigated after $5,10,15,20,25$ and 30 min of labelling. Tise result of this experiment is shown in Fig. 2. After 5 min, only the 110 kDa radioac- 


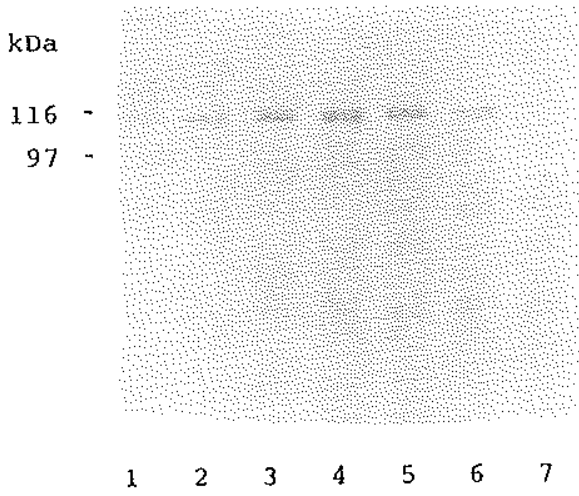

Fig. 2. Origin of the androgen receptor doublet. LNCaP cells, pre-jncubated for 60 min in methionine-free medium, were incubated for different time periods with $\left[{ }^{\text {"S }}\right.$ Stmethionine. Androgen receptor was immunoprecipitated using a specific antibody (tanes 1-6), or nof-specific mouse IgG (tane 7) and analyzed by SDS-PAGE and bloting. Incubation with ("5) S]nethionine kas for: 5 min (lane 1), 10 min (Jane 2), 15 min (Gane 3), 20 min (tane 4), 25 min (lane 5) and 30 min (tanes 6 and 7).

tively labelled androgen receptor protein could be detected; after longer incubation periods a gradual increase in the slower migrating androgen receptor protein $(1 / 2 \mathrm{kDa})$ and no further increase in the $110 \mathrm{kDa}$ protein was observed. The different kinetics of the de novo synthesis of the $110 \mathrm{kDa}$ and $112 \mathrm{kDa}$ androgen receptor proteins strongly suggest a time dependent con-

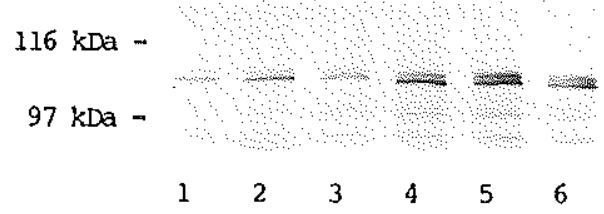

Fig. 3. Pulse labelling of androgen receplor in the presence of hormone. LNCal' cells, pre-incubated for $60 \mathrm{~min}$ in methio. nine-free medium, were incubated for different lime periods with $\left[{ }^{35} \mathrm{~S}\right]$ methionine in the presence of $10 \mathrm{nM} \mathrm{R} 1881$. Androgen receptor has immunoprecipitated using a specific antibody and analyzed by SDS-1'ACE and blotting. Incubation was for: 15 min (lane 1), 30 min (lane 2), 45 min (lane 3), 60 min (lane 4), 100 min (lane 5 ) and 130 min (lane 6).

version of the $110 \mathrm{kDa}$ protein into the $112 \mathrm{kDa}$ androgen receptor protein.

\section{Transformation of newly synthesized androgen re-} ceptor protein

In the next set of experiments, the possible influence of R1881 (methyltricnolone, a synthetic androgenic steroid) on the de novo synthesis and the conversion of the $110 \mathrm{kDa}$ androgen receptor protein was investigated. To this end LNCaP cells were incubated with $\left[{ }^{35}\right.$ S 3 methionine together with $10 \mathrm{nM} \mathrm{R} 1881$ for $15,30,45,60,100$ and 130 $\min$ at $37^{\circ} \mathrm{C}$. At each time point more radioactivity was found to be incorporated into the $110 \mathrm{kDa}$ than in the $112 \mathrm{kDa}$ androgen receptor protein (Fig. 3). From a comparison of the data presented in Figs. $1 B, 2$ and 3 , it can be concluded that in

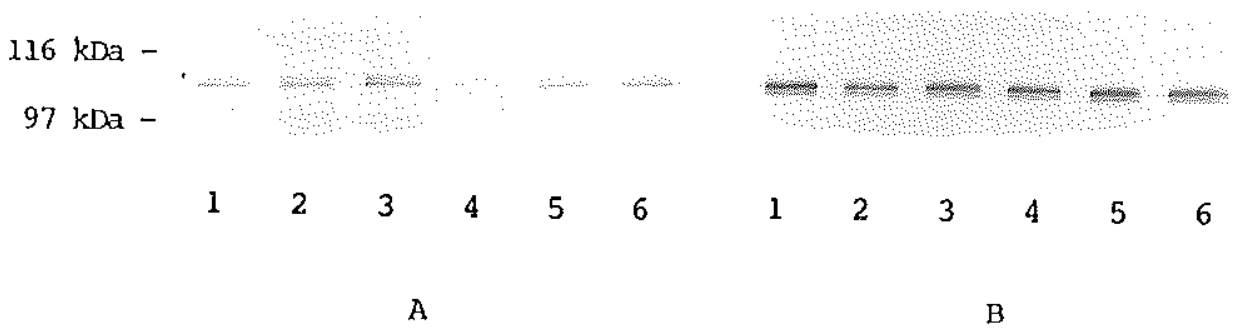

Fig. 4. Androgen receptor transformalion. LNCaP cells, pte-incuhated for 60 min in melhionine-free medium, sere incubated for different time periods with $\left\{{ }^{35}\right.$ S $\}$ nethinnine in the fresence of $10 \mathrm{nM}$ R1881. Thereafter cytosofs and nucleas extracts were prepared and receptor was immunopurificd as described. A: Autoradiogram. Lanes $1-3$ cyiosol, incubation was for: 10 min (lane 1), 20 min (lane 2). $30 \mathrm{~min}$ (lane 3). Lanes 4-6 nuclear extracts, incubation was for: 10 min (Jane 4), 20 min (lane 5), 30 min (lane 6). b: Immunoblat. Lanes 1-3 cytosol and lanes $4-6$ nuclear extracts. Incubation time periods as for $A$. 
the presence of hormone the conversion may occur at a much slower rate than in the absence of hormone.

To address this point further, receptor transformation, as characterized by the acquisition of tight nuclear binding activity, was investigated as a function of time after addition of R1881. Cells

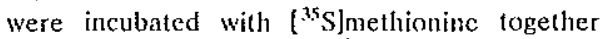
with $10 \mathrm{nM}$ R 1881 for 10,20 or $30 \mathrm{~min}$ at $37^{\circ} \mathrm{C}$, and thereafter cytosols and nuclear extracts were prepared. In Fig. $4 A$, it is shown that at all time points the $110 \mathrm{kDa}$ jsoform was the dominant species. Upon prolonged incubation, a gradual increase of the $110 \mathrm{kDa}$ protein in the nuclear extract was foond, while in the cytosolic fraction the amounts are virtually constant. This indicates that the newly synthesized $110 \mathrm{kDa}$ androgen receptor protein is able to bind hormone and that it can be transformed to a tight nuclear binding form immediately after synthesis. The transformed $110 \mathrm{kDa}$ isoform is not further converted to the $112 \mathrm{kDa}$ androgen receptor protein. From the inmunoblot of Fig. $4 B$ it is cleat that the cytosol fraction cannot be fully depleted of receptor protein by the hormone.

Is the $112 \mathrm{kDa}$ isoform also capable of undergoing transformation and is there a difference in transformation kinctics of both isoforms? In order to try to answer this question, homme depleted LNCaP cells were incubated with $\left[{ }^{35} \mathrm{~S}\right]$ methionine for $30 \mathrm{~min}$. After this incubation, a chase with cold methionine was donc either in the presence or absence of 10 nM R 1881 , for 10 and $20 \mathrm{~min}$ at $37^{\circ} \mathrm{C}$. In Fig. $5 A$ and $B$ it is shown that only an extremely small amount of androgen receptor protein fractionated into the nuclear fraction obtained from cells which were incu- bated in the absence of hormone. During the incubation with R1881 for 10 or $20 \mathrm{~min}$, both androgen receptor isoforms were able to undergo transformation to a tight nuclear binding form, showing similar transformation kinetics. A considerable amount of androgen receptor protein remained in the cytosolic fraction. This holds for the newiy synthesized receptor as well as for the pre-existing receptor protein (see Figs, $4 B$ and $5 B$ ). It is unlikely that the incomplete transformation is only caused by the short incubation time with R1881 because also after 1 h of incubation the cytosolic fraction was still not depleted (results not sliown). Furthermore, it is well-known that the amount of receptor protein in nuclear extracts of LNCaP cells reaches a near optimum 15 min after addition of hormone and remains constant on longer incubations (van Laar et al., 1991).

\section{In tilro androgen receptor dephosphorylation}

It hats been shown that the LNCaP cell androgen receptor is already phosphorylated in the absence of hormone and can undergo a rapid extra phosphorylation upon the addition of hormone (van Laar et al., 1991). The heterogeneity of the androgen receptor might therefore be linked to phosplonglation. To study this, LNCaP cells were incubated for 30 min with $\left[{ }^{35} \mathrm{~S}\right] \mathrm{meth}$ ionine and subsequently a cytosolic fraction was prepared. Portions of the cytosolic fraction were incubated for $60 \mathrm{~min}$ at $37^{\circ} \mathrm{C}$ with calf alkaline phosphatase in the presence or absence of phosphatase inhibitors. Phosphatase treatment led to an almost complete climination of the newly synthesized $112 \mathrm{kDa}$ protcin (Fig. 6A). Also pre-existing $112 \mathrm{kDa}$ androgen receptor was gradually

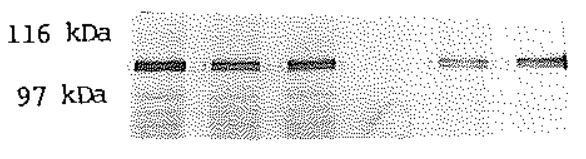
A
1
23
3456

6

B

1

3

Fig. 5. Hommone responsiveness of androgen receptor. LNCaP celts, pre-incubited for 60 min in methionine-free medium, weze incubited for $3 n$ min with [ "S meihionine. Thereafter a chase with cold methionine was dome either in the presence or absence of R1881, for 10 or $20 \mathrm{~min}$ at $37 \mathrm{C}$. Cytosols and nuclear extsacts were preparel as described. A: Automadiogram. Lancs 1 -3 cytosol and Ianes 4-6 nucleat exiract. Incubation was for: 0 min (lanes 1 and 4), (1) min (lines 2 and 5 ) or 20 min (lanes 3 and 6) in the presence of R1881. B: Immunoblot, balme $1-3$ cytosol and lanes 4-6 nuclear extract. Incubation time perionis as for $A$. 


\section{플}

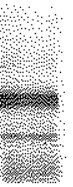

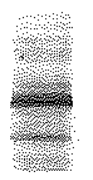

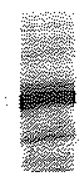

\section{A}

12

3

4

5

B

1

2

3

Fig. 6. Receptot dephosphorylation. Cytosols were srepared anul incubated with alkaline phosphatase as described in Materials and Methods. A: Autoradiogram. Incubation in the absence of alkaline phosplsatase (lane 1) and incubation with 100 units of alkaline phosphatase plus phosplıatase inhihiturs (banc 2) for 6 min at $37^{\circ} \mathrm{C}$. Lane 3 incubation will $21 \%$ ) unils phosphatase, lane 4 incubalion witl tolo units phosphatase and lane 5 incubation in the ahsence of phosghatase at $37^{\circ} \mathrm{C}$ for $60 \mathrm{~min}$. B: Jinmunoblot. Immonoblat corresponting to $A$ (lanes $3-5$ ).

eliminated upon phosphatase treatment, with a conconitant increase of the $110 \mathrm{kD}$ ) isoform, as seen in the immunoblot of Fig. 6/. Since the effect of alkaline phosphatase was blocked by the simultanenus addition of EDTA and $\mathrm{Nall}_{2} \mathrm{PO}_{4}$ (Fig. 6A), we conclude that the unshift in molecular weight from $110 \mathrm{kDa}$ to $112 \mathrm{kDa}$ is caused by receptor phosphorylation.

\section{Discussion}

The intracellular lncalization of steroid hormone receptors has been studied extensively (for review see Carson-Jurica et al., 1990). Steroid receptors are readily isolated from cellular cytosols in the absence of hormone, whercas after hormone treatment receptors are extractable only with salt from nuclei. With the production of specific antireceptor antibodies, the progesterone, estrogen and androgen receptors were found to be primarily nuclear in the absence of their respective ligands (King et al., 1984; PerrotApplanat et at., 1985; Ruizeveld de Winter et al, 199()).

In the present report, it is shown that the androgen receptor is synthesized as a single protein of $110 \mathrm{kDa}$, and that a $112 \mathrm{kDa}$ isoform is generated through a rapid post-translational modification. From dephosphorylation experiments with alkaline phosphatase it was concluded that the post-translational modification is in fact recepter phosphorylation. This phosphorylation occursed independent of hormone, and therefore the upshift in molecular weight reflects the formone independent ( $=$ basal) phosphorylation of L.NCaP cell androgen receptor. Recently, it was shown that administration of R1881 to LNCaP cells resulted in an increase of the amount of nuclcar extractable androgen receptor and that the phosphate-to-protein ratio of androgen receptor extracted from nuclei 5,15 and $30 \mathrm{~min}$ alter RI881 administration to LNCAP cells was constant. This indicates that a hormone dependent phosphorylation step occurs before or during transformation to the tight ruclear binding form, but not after transformation (van Laar et al., 1991). The present results show that the 110 kDa androgen receptor protein can be trans. formed immediately after synthesis, upon the addition of hormone, and that the hormone dependent phosphorylation step is not reflected in a further increase in molecular mass. The $112 \mathrm{kDa}$ isoform can undergo transformation upon addition of hormonc as well.

The protein kinases which are involved in phosphorylation of the androgen receptor have not yet been identified. On the basis of our results, it can be suggested that the hormone independent phosphorylation occurs in the cytoplasm before translocation to the nucleus. It has been postulated for steroid receptors that the basal phosphorylation is necessary for the acquisition of hormone binding capacity (Migliaccio et al., 1986). It was shown that both isoforms of the androgen receptor can be photoaffinity labelled with [ $\left.{ }^{3} \mathrm{H}\right] \mathrm{R}$ 1881 (van Laar et al., 1990). This would 
imply that all the newly synthesized $110 \mathrm{kDa}$ androgen receptor protein is phosphorylated on several sites. The phosphorylation at these sites may occur in a random fashion, whereby only one of the phosphorylations causes an apparent upshift in molecular mass. Recently it has been shown that the chicken oviduct progesterone receptor is differentially phosphorylated on three sites in the absence of hormone (Denner et al., 1990).

Another possible function for the hormone independent phosphorylation of androgen receptors might be that it serves to target the untransformed androgen receptor protein to the nucleus. In the absence of hormone androgen, receptors are only loosely bound to chromatin, and are easily extracted in the cytosolic fraction (Fig. 5B). Addition of ligand might result in the phosphorylation of a certain subset of androgen receptor proteins, and in the transformation to the tight nuclear binding form. Another subset of androgen receptor proteins is possibly not hyperphosphorylated upon addition of hormone, and is lost from the nucleus upon homogenization of cells. Surprisingly a rather large amount of androgen receptor protein seems to belong to this subset. in this respect, it would be interesting to compare the extent of phosphorylation of the transformed nuclear androgen receptor and the untransformed cytosolic androgen receptor after hormone stimulation of LNCaP cells.

After pulse labelling with $\left[{ }^{35}\right.$ S $]$ methionine of hormone depleted T47D human breast tumor cells, Sheridan et al. (1989) showed that the B form of the progesterone receptor is synthesized as a single B protein of $114 \mathrm{kDa}$. The mature B triplet is formed $6-10 \mathrm{~h}$ later by phosphorylation. Interestingly, phosphorylation of the newly synthesized androgen receptor in LNCaP cells was a fast process $(10-30 \mathrm{~min})$. The explanation for the difference in phosphorylation kinetics of the progesterone and androgen receptors in the two cell systems is not known.

Recently, the LNCaP cell androgen receptor cDNA was cloned and sequenced. One point mutation $(G \rightarrow A)$ was found near the $C$-terminus, which results in Thr- 868 being converted to Ala in the LNCaP androgen receptor. The mutation was confirmed in several independent cDNA clones and by polymcrase chain reaction of androgen receptor exon 8 in genomic LNCaP cell DNA (Harris et al., 1990; Veldscholte et al., 1990). Androgen receptor heterogeneity observed in LNCaP cells, however, is not associated with the described point mutation because the 110-112 $\mathrm{kDa}$ doublet is also observed after expression of wild type androgen receptor protein in $\operatorname{COS}$ cells (Jenster et al., manuscript in preparation).

The present investigation illustrates that androgen receptor heterogeneity in LNCaP cells is linked to receptor phosphorylation but not to the acquisition of hormone binding capacity or the hormone dependent transformation to a tight nuclear binding form.

\section{Acknowledgnent}

This investigation was supported by the Dutch Organization for Scientific Research (NWO) through GB-MW (Medical Sciences).

\section{References}

Beato, M. (1989) Cell 56, 335-344.

I3lok, L.J., Mackenbach, P., Trapman, J., Themmen, A.P.N., Brinkmann, A.O. and Grontegoed, J.A. (1989) Mol. Cell. Endocrinol. 63, 267-271.

Carson-Jurica, M.A., Schrader, W.T. and O'Malley, B.W. (1990) Endocr. Rev, 11(2), 201-220.

Denner, L.A., Schrader, W.T, O'Malley, B.W. and Weiget, N.L. (1990) J. Biol, Chem. 265, I6548-16555.

Dougherty, JJ., Puri, R.K. and Tof, D.O. ([984) J. Biol. Chem. 259, 8004-8009.

Evans, R.M. (1988) Science 240, 889-895,

Harris, S.E., Rong, Z., Harris, M.A. and Lubahn, B. (1990) 73nd Annual Meeting of the Endocrine Society, En. docrine Society, Baltinore, MD, Abstract 275.

Hotoszewicz, J.S., Leong, S.S., Karwinski, E., Karr, J., Rosen. thal, H., Chu, T.M., Mirand, E.A. and Murphy, G.P. (1983) Cancer Res, 43, 1809.

Horwitz, K.B., Mochus, M.B. and I.essey, B.A. (1982) Cell 28, $633-642$.

Jentoft, N. and Deasborn, D.G. (1979) J. Biol. Chem. 254 , $4359-4365$.

King, W.J. and Greene, G.L. (1984) Nature 307, 745-746.

McDonnell, D.P., Mangelsdorf, D.J., Pike, J.W., Ilaussler, M.R. and O'Malley, B.W. (1987) Science 235, 1214-1217,

Migliaccio, A, Rotondi, A. and Auricchio, F, (1986) EMBO J. 5, 2867-2872.

Perrot-Ajplanat, M., Logeat, F., Groyer-Picard, M.T. and Milgrom, E. (1985) Cancer Res. 47, 2652-2657.

Quarmhy, V.E., Kemppainen, J.A., Sar, M., Lubah», D.B., 
French, F.S. and Wilson, E.M. (1990) Mol. Endocrinol. 4, $1399-1407$

Ruizeveld de Winter, J.A., Trapman, J., Brinkmann, A.O., Boersma, W.J.A., Mulder, E., Schroeder, F.H., Claassen, E. and yan der Kwast, T.H. (1990) J. Pattol. 161, 329-332. Sheridan, P.L., Krell, N.L., Gordon, J.A. and Horwitz, K.B. (1988) Mol, Endocrinol. 2, 1329-1342

Sheridar. P.L., Francis, M.D. and Horwitz, K.B. (1989) J. Biol. Chem. 264, 7054-7058.

Tilley, W.D., Wilson, C.M., Marcelli, M. and McPhaul, M.J. (1990) Cancer Res. 50, 5382-5386.

van Lar, J.H., Voorhorst-Ogink, M.M., Zegers, N.D., Boersma, W.J.A., Claassen, E, van der Korpu1, J.A.G.M.,
Ruizeveld de Winter, J.A., van der Kwast, Th.H., Mulder, E., Tramman, J. and Brinkmann, A.O. (1989) Mol. Cell. Endocrinol. 67, 29-38.

van Laar J.H., Boft-de Vries, J., Zegers, N.D., Trapman, J. and Brinkmann, A.O. (1990) Biochem. Bioplys, Res. Commun, 166, 193-200.

van Laar, J.H, Berrevoets, C.A., Tranman, J., Zegers, N.D. and Brinkmann, A.O. (1991) J, Biol. Chem. 266, 3734-37 Veldschotte, J., Ris-Stalners, C., Kuiper, G., Jenster, G., Berrevoets, C., Claassen, E., van Rooij, H., Trapman, J., Btinkmann, A.O. and Mulder, E. (1990) Biochem. Biophys. Res. Commun. 173, 534-540. 


\section{CHAPTER 4}

\section{LOCALIZATION AND HORMONAL STIMULATION OF PHOSPHORYLATION SITES IN THE LNCaP-CELL ANDROGEN RECEPTOR}

George G.J.M. Kuiper, Petra E. de Ruiter, Jan Trapman, Wim J.A. Boersma, J.Anton Grootegoed and Albert O. Brinkmann

Biochem. J. (1993) 291, 95-101. 


\title{
Localization and hormonal stimulation of phosphorylation sites in the LNCaP-cell androgen receptor
}

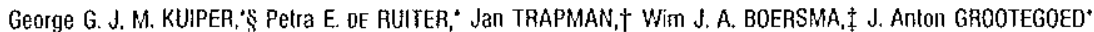 \\ and Albert 0 . BRINKMANN'

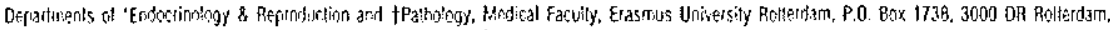

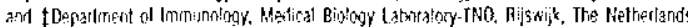

Phospliorylation of the andregen receptor in humball prostate tumour cells (LNCaP) is increilsed by anddition of androgers to intiot cells. Druble-label studies, using ["S]methionine incorporalion into receptor frotein. and $\left.\left.\right|^{3} \mathrm{P}\right] \mathrm{P}$, to label mesabolically receptor phosplunglation siles, have cmablesl us an delemine the phosplate content, telative to receptor protcin, of hollo noltransfomed and transformed androgen receptors genernted in intact LNCaP cells. No net clange in the phosphorylation of flec intact $110 \mathrm{kDa}$ sternit-bieding component of the androgenreceptor complex was found unon transformation to the light auclear binding Form in the intiel cell. Partial protenlysis of androgen scceptor protein melatolically lithelled with [ $\left.{ }^{22}{ }^{2}\right] \mathrm{P}$, and photolabelled with [ 1 t] R 1881 (mellyyitricnolome) revealed that phospliorylation occurs mainly in the N-termilyal trams-activation clomain, whereas no phosphonglation was delected in the steroidand DNA-bindling domains. The locattion of most ( $>90 "$.$) of$ the liormonality regutatcd pliospliorylation sitcs in the $N$-teriuinal trems-activalion sInmain stgegests a role of phosphonylialion of the ansirogen receptor in transcription tegulationt.

\section{INTAOOUCTION}

Stcroidtlomone recentors are thime-acling gene-regulating protcins, involved in the accomplishmest of sternid-hommeinduces collulitr responses. Upon binding of tomone. the recez̧tur hormone complex undergoes a confornmationat change ciallesl trans Fernation, whith is thought to precesle hinding of the conples to botmone-seaponsise elements in the target-cell genome [1].

A putative role of receptor phosphorylation in sternithormone actian has long been recognized. On the hasis of eflects of ATl' on lwronone hinding and transformation of sleroid receptors, it his been suggested that these wio processes are

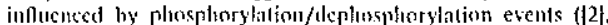
and references flicrein). Ample evidence flas now ixen provideo that the progesternue, glucoenticotil, nestrogen, androgen and vitimuin 1) receptors exist as phusphoproteins even in the athence of ligand [3-7]. Adtlitomal pinosploovylation has beco ohsersed upeil lormone binding [2]. II hiks been shown that basil phosphorslittion is indiepensable for the acesuicition of ligatedbinting activity of the neslatiol receptor [5]. Indirect evidence has been provifled for a similar role of phosphorylation in Jigand binding of several other sterotel receptnos [2]. Various funclional roles for hormene-induced receptor phosphorylation have heen proposed, ceg. elissociation of associaled proteins (stctl as hosp 901). interaction with other transcription facters and specific hinding to hormbur-icsponsive clements [2]. All steroid reseptors thus far described have mulliple plusphorylation sites [8 14].

$W_{e}$ hase sltdied andogen-receptor heterogeneity ind synthesis in the hmonan LNCip' cell line (Lymph-Node Curcinoma at the Prostate cells) 17,15]. In these cells, the indrogen recentor is a helerogeneous protein which is synthesizes is at single

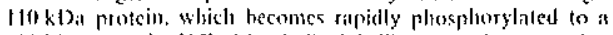

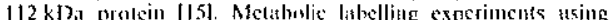
["2P, indicates that the androgen seceptor is a phosphoprotein

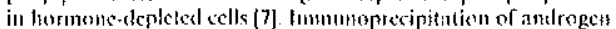

recętors from total celi lysates strowed an almot1 2-fold increase in receptor ploosplorylation within 30 min alter farmone idntinislratiof as compured with control cells [f(a).

It has also heell shown thit the amount of andiogen-eceptos protcin in nuciear extracls of LNCas ceils reaclies a neatroptionum within 30 min afler addition of hormone, whereas the cytosolic fruction is not completely depleted $\left[15, t_{1}\right]$. The fact that Iransformation to the tight muckar binding form and lomoneinducal hyperphosplonylation hoth reach an ntimsm within 30 min iffer addition of hormone to LNCitP tells suggests latat there might be a link hetween bolh processes.

In the present study we have uxed monnclonal antibodics against the athelrogen receplor to purify cytrosolic nomtransformed and nuclear transformed complexes from " $"$ p. lathelled atnd "S-lishelled LNCaP cells exposed to amirogens at $37^{\circ} \mathrm{C}$. Data oblained indicates that there is a similar degree of phosplorylation of the androgen receptor, hefore ank alter tratsformation to the tight nucleatr hinding form in the intact csll.

Using limiled protenlysis it wis establislice that most of the phesphorylation sites ate localized in a tram-activation domasin in the N-terminal sart of the androgen-receptor protein.

\section{MATERIALS AND METHODS}

\section{Materlais}

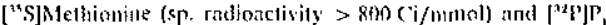
(carrier free) was ohtained from Antersham (1.ittle Clailfomt.

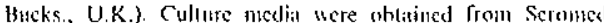
(Rertin, Germainy). Felal-catl serum was oblaincd From

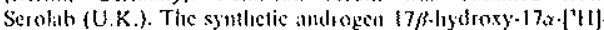

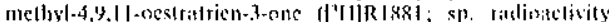
- $87 \mathrm{Ci} /$ mmol) and anlahelled [RisRl were purchissed from NEN-DupenI (Dreicich, (icumimy).

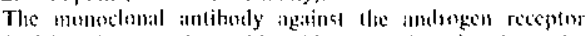

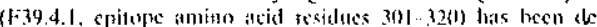


scribed previously [i6-18]. The poiyclonal antisera against the androgen receptor spo6t (epitope amino acid residues 301-320), sphor (cpitope amino acid residues 899-917) and spl97 (cpitope atmiun acid fesidtues 1-20) were prepared by previously publisled procedures [19]. The polyclonit itmtiserum (spoto6) recognizes the $110.112 \mathrm{kD}$ a androgen receptor on Western immunobluts, but is unable to inleracl with the nalive androgen receptor in solution complexed with radioactive ligand [19]. The polyctonal antisera sp 197 (decsigned as described in [20]) and spost hoth contain higititre antibodies against the androgen teceptor, as was shown by immunoprecipitation and Western blotting [18].

All other chemiculs and reagents were purchilsed from citier Sigma Clicmical Co. (St. Louis, MO, U.S.A.) or Merck (Diarmstadt, Germany).

\section{Cell culture}

The L.NCal' cell line was cuftured as described meviousiy [16]

\section{Melatollo labeilng wilt f"Slmethlonlne and/or ["P]P,}

For phosphorylation studies, LNCaP cells were incubated for 4 th at $37^{\circ} \mathrm{C}$ in a phosplate-frce Kiebs-Ringer hulter at pll 7.311 $8 \mathrm{mM} \mathrm{NiCl}, 4.75 \mathrm{mM} \mathrm{KCl}, 25 \mathrm{mM} \mathrm{NallCO}, 1.2 \mathrm{mM}$ $\mathrm{MgSO}_{1}, 2.5 \mathrm{mM} \mathrm{CaCl}$ ) contianing $0.2 \%(\mathrm{w} / \mathrm{v})$ glucose and amine acids (minus methionine) according to (he formulation of Fagle's Mintmum Escential Medium, and $0.15 \mathrm{mCi} / \mathrm{ml}$ ["2PJP, and $10,{ }_{1} \mathrm{Ci} / \mathrm{ml}\left[{ }^{3} \mathrm{~s}\right.$ ] methionine when appropriate.

Incubations were stopped by removal of the medium, im. medialcly followed by a wasl with PBS at 20 "C. Subsequently, the cells were lysed in buffer $A$ [40 mM Tris/HCl, pH 7.4. I mM EDTA. 10$)^{\prime \prime \prime}(v / v)$ glycerol, $10 \mathrm{mM}$ dithinthreitol, $10 \mathrm{mAs}$ $\mathrm{Na}_{2} \mathrm{MnO}_{1}, 50 \mathrm{mM} \mathrm{NaF}$, supplemented with $\mathrm{I} \%(\mathrm{v} / \mathrm{v})$ Triton $x-100,0.5 \%(w / v)$ sodiun deoxycholate, $0.08 \%(w / v)$ SDS, $0.6 \mathrm{mM}$ plenylmethanesulphonyl funride and $0.5 \mathrm{mM}$ bacitascin it $4^{\circ} \mathrm{C}$. The lysate was centrifuged $(30 \mathrm{~min}, 100000 \mathrm{~g})$ and andregen receptor was inmunoprecipitated from the supernationt.

\section{Prepasation of cylosol and nuclear extract}

Approx. $6 \times 10^{7}$ cells were collected in $5 \mathrm{ml}$ of huffer $A$ supplemented with o.f nM plienylmethanesulphonyl nasride, $0.5 \mathrm{mM}$ hacitracin and $0.2 \mathrm{mg} / \mathrm{ml}$ leupeptin. Cells were homogenized, dre homogenate was centrifuged for 10 min at $800 \mathrm{~g}$. and the cylosol was prepared by centrifugation of the supermatant at insogen $\mathrm{g}$ for $30 \mathrm{~min}$ at $4^{\circ} \mathrm{C}$. The nuclear pellet Wils washed witl bufter $A$ containing $0.2 \%$ Triton $X-100$, and then will, bufter $A$ without additions. Sulseguently, the nuclear pellet was extracted will buffer $A$ (pll 8.5) continining $0.4 \mathrm{M}$ $\mathrm{NaCl}$ for 1 it at $4^{\circ} \mathrm{C}$. Thie muclear extracl was centrifuged at $111500 \% \mathrm{~g}$ !or 30 min.

Immunoprecipitatlon, electrophorests, blolting and autoradlography These were done bs previnusly puhtished procedures [15,16].

Double labelling of LWCaP-cell androgen receptor with ['HR 1881 and ${ }^{n} \mathrm{P}$ and cleavage with $\boldsymbol{x}$-chymoliypsin

I. NCaP cells were incubited with ['P]P, as described for 4 h.
Then ['H]R 188 | was added to a final concentralion of in nMt and the jucubation was continued for 30 min at $37^{\circ} \mathrm{C}$. After washing with ice-cold PJS, the cells were irmadialed for $2 \mathrm{~min}$ at the surface of an U.v. trans-itluminator (wavefengtit $300 \mathrm{~nm}$. Cbremato-Vue-1tansilluminator; UV Products he., Sin Gabriel, CA, U.S.A.). A cell lysate was prepared, and $1 \mathrm{ml}$ portions of it (corresponding to approx. $3 \times 10^{3}$ celts) were precipitated with the F39.4.1 monoclonat antibody against the androgen receptor, bound to goat anti-(monse $\lg (i)$-agarose $[15,16)$. The pellets were transferred to a clean Eppendarf tube, and $100 / \mu$ of TEG buffer $(40 \mathrm{mM}$ Tris/ $\mathrm{HCl}, \mathrm{nH} 7.5,1 \mathrm{mM}$ EDTA and $10 \%$ glyceroi) wis added. Digestions were carried out with 0.5-1.B / of $\alpha$-clymotrypsin (Merck: trace amounts of trypsin activity present) for 30 min at $4^{\circ} \mathrm{C}$, with constant mixing. At the end of the digestion, 25 , of S-fold-concentrated SDS/PAGE sample buffer was added, and the tuhes sicre heated at $95^{\circ} \mathrm{C}$ for $3 \mathrm{~min}$. Samples were then centrifuged at $10009 \mathrm{~g}$ for $2 \mathrm{~min}$ and subjected to SDS/PAGE (II \%-acrylamide gel). Lanes were cut into $2 \mathrm{~mm}$ stices, and the slices were incubatcd overnight in $1 \mathrm{ml}$ of $0.1 \%$ SUS/TEG bulTer. The radioactivity of 750 fl samples was determined witl a Packard Tri-Carh 25A9 TR Jiquid-scintillation counter, with a douthle-label setting for "IJ and ${ }^{* 2} \mathrm{P}$.

\section{Measurement of receplor-bound phosphate of transformed and non-transformed complexes atter whofe-cell Incubatlon with} R1881

Mctaholic tahelling of LNCaP cells with $f^{32} p_{P}$, and ["Slmethionine was performed as descrihed herein. Netween 5 and $30 \mathrm{~min}$ before the end of the labeiling period. RI88I was added to a final concentration of $10 \mathrm{nMf}$ and incubation was continued at $37^{\circ} \mathrm{C}$. Subsequently the cells were homogenized, and cytosolic fractions and nuclear extracts were made. After immunoprecipitation with the F.39.4.1 monoclonal antihody, SDS/PAGE and blutting to nitrocellufose, the blots were incubated with the polyclonal antihody split [1]1. After colnur development, each lane was cut into 2 mm slices attu the slices were dissolved in $10 \mathrm{ml}$ of Filtercount cocktail (Packard). Radioactivity was determined with a Packard Tri-Carb 2500 'TR liquid-scintillation counter, with a double-lahel setting for ${ }^{32}[$ and "S.

\section{Labe:llng of LNCaP-cell androgen receptor with "2P and partial profeolylic cleavage with $\alpha \cdot$-chymolrypsitt}

LNCaP' cells were incubated witl [ $\left.{ }^{2} \mathrm{P}\right] \mathrm{P}$, as described icrein After labefling for $4 \mathrm{~h}, \mathrm{R} 188 \mathrm{I}$ was added to a final concentration of $10 \mathrm{nM}$ and the incubation was continued for $30 \mathrm{~min}$ at $37^{\circ} \mathrm{C}$. $A$ total cell lysate was prepared and the androgen recentor was immunoprecipitated from I mol portions of the cell lysate (corresponding to ahout $3 \times$ [D' cells) witl the F39.4.1 monnclonal antiboty against the androgen receptor bound to goat anti(nouse $\mathrm{lg}$ (j) -agarose [15.16]. Digestings were carried out with $\alpha$ chymotrypsin (Acrek) in the range $12.5-150$ ng in $100 \%$ of TFG buffer (nH 7.4), for $3 n$ nin at $4{ }^{\circ} \mathrm{C}$ with constant mixing. At the end of digestion, SDS/PAGE sample buffer was added, and the tuhes were heated at $95^{\circ} \mathrm{C}$ for 3 min. Samiles were then centrifuged at 10non $g$ for 2 min and subjected in SDS/PAGE (II "\%-acrylamide gel) and hlotted on to nitrocellitose as described previously [IS]. The filter was air-dricd and exposed to Ilyperfilm-MiP (Amersham) wilh intensifying screens for 16-72 h at $-80{ }^{\circ} \mathrm{C}$. Therealter holots were incubated witl receptor-specific polyctonal anticerat ats described previously [1S]. 


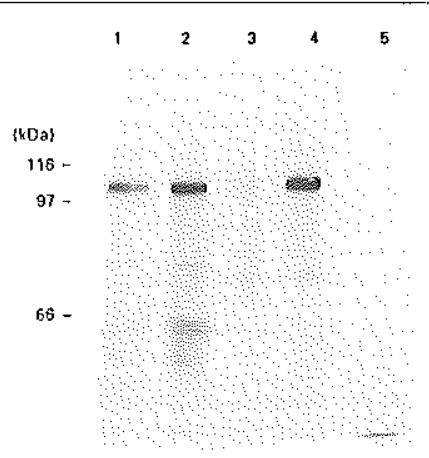

Flgure 1 kormone-dependent androgen-seceplor phosphorylation and tight nuclear blanding

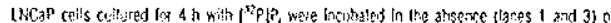

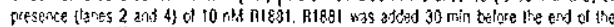

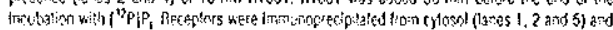

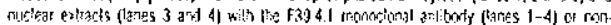

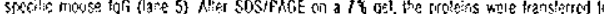

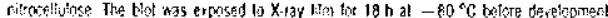

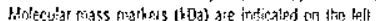

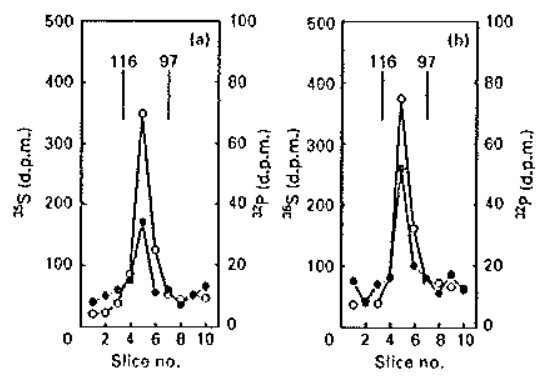

Figure 2 Hotmone-dependent androgen-teceplor phosphorylatlon

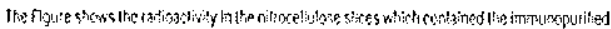

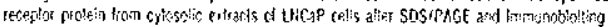

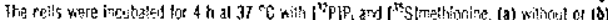

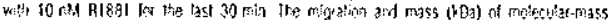

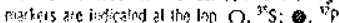

\section{RESULTS}

\section{Receptor phosphorylalion and light nuklear binding}

ln the absente of lommone, indrogen receptors ase only loosely botnd to chromatin, and ase casity extritcted in the cytosolic fraction. Upon addition al lormons, andegen receptors are fransformed to at form which is tightsly bound in the cell nucieus, and ciut only be recovered after extraction of nuclei with high salt (0.4 $\mathrm{M} \mathrm{NaCl}$. From the fact that transformation of the androgen receptor to the tight nuclear hinding form and hormone-induced hyperphosplonylition both reach an ontimum within 30 3in
Table i Phosptorylallon of androgen receplors in cylosolic (C) and nuclear (iㅔ) extracts

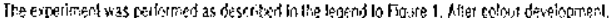

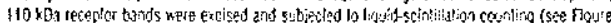

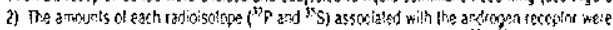

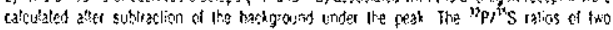

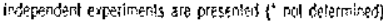

\begin{tabular}{|c|c|c|c|c|}
\hline \multirow{3}{*}{$\begin{array}{l}\text { Incutalion liase } \\
\text { with RIRSY (min) }\end{array}$} & \multicolumn{4}{|c|}{${ }^{n} 8 \gamma^{\prime \prime} \mathrm{S}$ ral:0 } \\
\hline & \multicolumn{2}{|c|}{ Expl 1} & \multicolumn{2}{|c|}{ Expl 2} \\
\hline & $\hat{c}$ & $\mathrm{H}$ & $\mathrm{c}$ & $H$ \\
\hline 0 (m) horlsine & 011 & - & 005 & - \\
\hline 5 & 012 & - & $\cdot$ & - \\
\hline 15 & 014 & $0 \nmid 5$ & 0.07 & 007 \\
\hline 30 & 0 †9 & 019 & 011 & 011 \\
\hline
\end{tabular}

after addition of hormone In LNCaP cells, it could he suggested that there is a link betwcen both processes.

In order to address this question, receptors were isolited hy immunoprecipiration from both cytosol and nuclear salt extracts of "P-kabelled LNCaP celis that were incuhated at $37^{\circ} \mathrm{C}$ for $30 \mathrm{~min}$, in either the presence or the absence of horimone (RI881). Aidrogen receptor was subjected to SDS/PAGE, and bintted on to nitrocellulose. Iu Figure 1, an autotatiogram of such an experiment is stiown. in the ahsence of hornone, almost all of the phosphorylated receptor is recovered in the cytosolic fraction: (compare lanes 1 and 3 with lanes 2 and 4 ) and is therefore regarded as non-transformed. Upon addition of hormone, hyperphosphorylated androgen reseptor is present in the nuclear exiract (lane 4). However, not all androgen receptor hecomes transformed to the ligit nuclear binding form, becaste in the cytosolic fraction (lane 2) also hyperphosplinglated receptor is present.

The extent of receptor plosphorylation was determined in double-label experintents, using [ ${ }^{35}$ Sjmethionine to measture receptor protein and [ $\left.{ }^{32} \mathrm{P}\right] \mathrm{P}$, to measure receptor plonsphite. This approach enathles the deternination of the phospliate content, relative to the amount of receptor protein. of both the nontransformed andiogen receptor and the androgen-receptor molccules that are transformed to the tight muclear hinding form in intact LNC.aP cells exposed to R 1881 at $37^{\circ} \mathrm{C}$. In Figures 2(a) ant $2(h)$ the profiles of "S and " 2 radioactivity associated with the II0 kDa androgen-receptor protein are shown. In the nres. ence as well as in the absence of hotmone an equal amount of receptor protein was immunoprccipitated ("S label). Incuhittion of the cells with hormone, lowever, increased the amount of radioactive phosphate associated with the receptor (Figure 2h). Datta from two independent experiments in which cells were incubated for various time periods with R/88t are summarized in Table 1 . The androgets receptor is already phosphorylaled in the absence of hormone, and uzen addition of hotmone a 1.8 fold stimulation of phosphorylation for the cytosolic extract was observed, However, the ratio of ${ }^{x} P$ to ${ }^{* 75} \mathrm{~S}$ radionctivity specifically associsted with the $110 \mathrm{kDa}$ androgen-recentor protein did not change upon transformation to the tight nuclear hinding form.

Locallzation of ghosphorylation siles with regard to the tunclional domalns of the androgen receptor

The androgen receptor from LNCaP cells after plintolitelling in sim with [ HI]R I8sI is a protein of $110 \mathrm{kDa}[18,21]$. Upon timited 

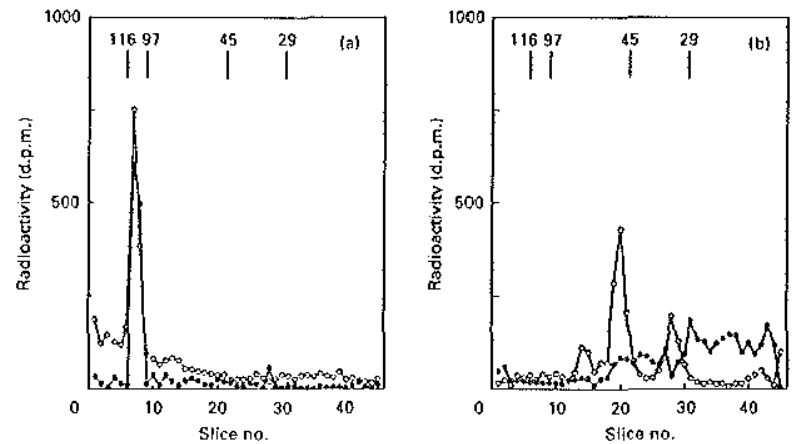

Figure 3 Chymotrpsin cleavage of "p. and "H-R1881-photolabelfed androgen receptor

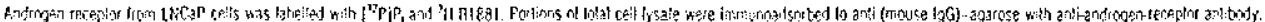

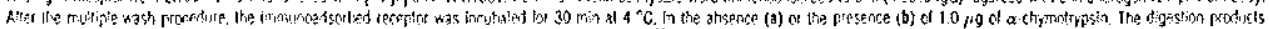

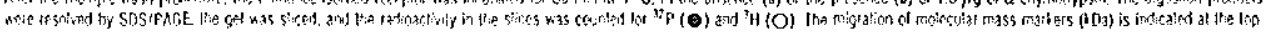

Fabie 2 Hatlo of ${ }^{12} \mathrm{P}$ and ${ }^{\mathrm{H}} \mathrm{H} \cdot \mathrm{H} 1881$ of the Inlact receplor and the tgenerated chymoliyplic tragements

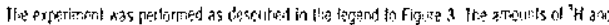

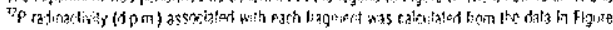

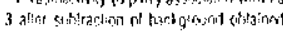

\begin{tabular}{|c|c|c|c|}
\hline 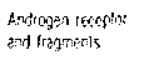 & $\begin{array}{l}y_{p} \\
\left\{y_{p \times 1} \mid\right.\end{array}$ & $\begin{array}{l}\text { 'H } \\
(\mathrm{Ap} m)\end{array}$ & Ma: \\
\hline Intel & $10: 57$ & 875 & 12 \\
\hline$\sim 70$ Hed ldy & 18 & 123 & 014 \\
\hline$-45+0.3+209$ & 85 & 695 & 012 \\
\hline 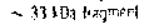 & 15 & $23 \pi$ & 006 \\
\hline
\end{tabular}

prolenlysis, a Iryptic fragenent of $\sim$ 3ll $k$ Dil contrining the sleroisl-bimaling elominin ankl a $\sim 45 \mathrm{kl}$ ) al clismostrytic fragment combaining the DNA- ant sterostl-binting domain iffe generated

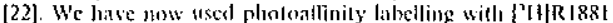

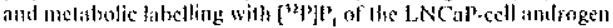
receptor to detcet possible plossphorylation siles within the DNA- atd/or ligand-himating domain. Double-1ithelled rescpinis

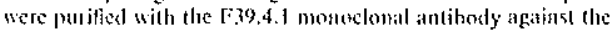
introgen receptor, hefore grolenlysis with a-chymolrypsin. Fragments were subsequeatly anilysed by SDS $/$ PACE, followed by liquid-scinlillialion counting of gel stices. Figure $3($ al) shows

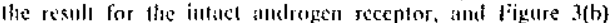
slows the restit after patrial difgestion will a-cliynmotrosin.

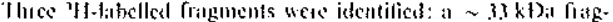
ment conbataing the ligand-himeling dounim. a $\sim 45 \mathrm{kD}$ a liagment cncompissing the ISNA- amet ligind-binting domain.

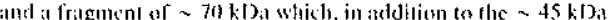
fraphent, also contatios piert of the N-1esmimat domain of the receplar (sce atso Jigure 5). All lluce lialgunents reiteded on immmmblnts wilh lles splas antisermm, which is directed to the

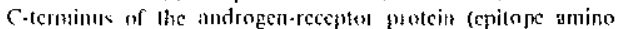
acit $\times 59917$, indicating that the Jragments contatinesl at leasl

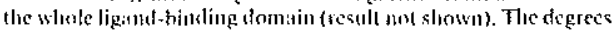

of phosphorytation of the various fragments generated by $\alpha$. cliymotrypsin and the intact recentor were determined and expressed as the ${ }^{32} \mathrm{P} / \mathrm{N} / \mathrm{F}$ ratio (1)ible 2). The ${ }^{32} \mathrm{P} /{ }^{3} \mathrm{H}$ ratio for the intace receptot protein was more than fol times thitt for the vitious fralgments generalcd conlitining the DNA- and sicroidhinding domains.

It ean he concludeal that $90 "$ "is or more of the phosphorylation sites are oulstile tle DNA- and ligatd-binding domain. In Figure 3(b) a large amount of ${ }^{72} \mathrm{P}$ is associated with fragnents of $<29 \mathrm{kI})_{31}$, probialily protentytic fragments of the $\mathrm{N}$-termital domain of the androgen receptor.

To andlyse in more detail the proposed N-1ermimal domain phosphorylation of the LNCaP.cell androgen receplor. immunoprecipitated receptor was incubaled with limilesl amounts $(12.5-100 \mathrm{ng})$ of $\alpha-$ chymntrypsin. The partial digests of :P-fabelled attedrogen receptor were analysed by SDS/PACE, immomoblofting and autoradingraplyy. Tile resulls of linese experimenls are slinwn in Figuse 4. In this Figuse, lane If, contaiuing the intact androgen receptor, displatycd the prescice of a single phosplarylated species of $110 \mathrm{kD}$ a. Lanes $\mathrm{l}-3$ reflect the receptor preparations incutated witl decreasing anounts of

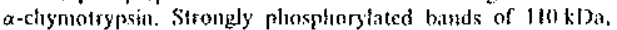
$85-90 \mathrm{kD}$ il, $\sim 50 \mathrm{kDa}, \sim 40 \mathrm{k1}$ a, $\sim 25 \mathrm{kDa}$ ankl a weakly pliosphorylated hand of $\sim 15 \mathrm{k} \mathrm{D}_{\mathrm{a}}$ were observed

In bares 4 o the corresponding immunoblos is slown atier slitining with the spllat antisertam (epitope amino acid residues $301-320)$. All the plosplinglated bands from the attoradingram (hnes I-3) react will this antihody, cxeent for tle $-25 \mathrm{kl}$ a hand. Particularly interssting is the - $50 \mathrm{kDa}$ fratgment, which reacls with the spnal antiboty and is strengly phosphorylated. slonsing latal indect the N-terminal fomain is lieavily plusplinglatcal. This $\sim$ so kloa fragment also reacts on hlats witl the sol97 antiser(II), which is directco aganst an epitope at the N-terminus (aumino acid residues $I-20$ ), showing that this frugnent encompases the whote N-termimal dismain of the receptor (sct lanes 8 and 9). The $\sim 50 \mathrm{kD}$ a fragment does not reat wilh lise $s$ pho6 antiscrum (cpitope atminn acid residtes 899. 917; result mol slows). On (he immunnblot an atditional fragment of $-70 \mathrm{kDa}$ is not phosphoryfated (cf. lanes .3and 6). 


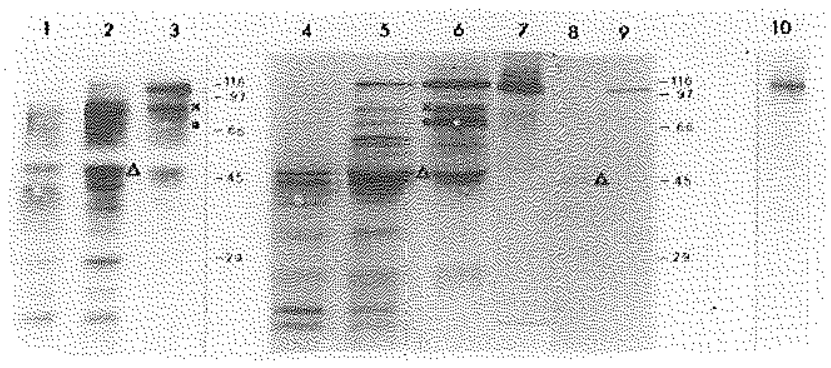

Flgure 4 Proleotytlo dlgestion of phosphorylated androgen receplors wilh $x$-chymolrypsin

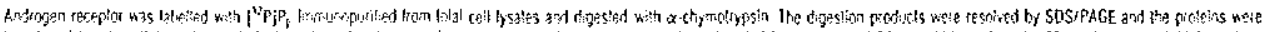

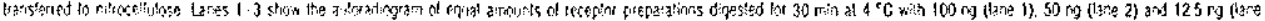

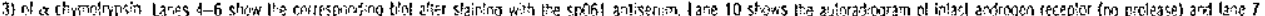

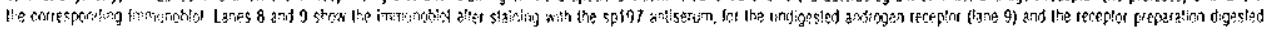

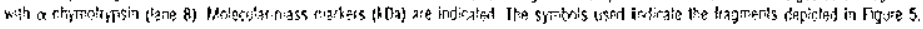

This is mot likety identicil with the $-70 \mathrm{kDa}$ fragnent showin

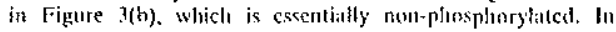
addition, a sl rongly phosphorylated fritgment of $85.90 \mathrm{kDa}$ was observed (cl. Halles 3 and 6). 'This frameat reacts on immutuoblots

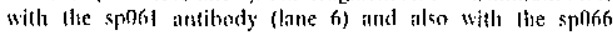
intiscrum directed against an epilone at the C-lerminus tamino icid restidues 8y9-1)17; result ant shown).

l:oun these resulls, it is very likely that the main phosphorylation sites of the LNCar-cell andinget receptor are tocaled in the N-terminat demain, probably in the regien of amino acill residues I- . In (Figure S)

Parlial nortenlysis of plossphorylated androgen recepter from conlrol cells (not inculated in the presence of hormons) revealed al similar phosphopegtide pattern (o) litit shown in Figure 4 for recentor in the presence of homme. The only alifference was the less strong labdling intensity of the intact recepter and the proteolytic fritgments.

\section{DISCUSSION}

In tle pesent study we thive compatred live degece of phosplustylition, in hermone treated cells, of cyloseslte receptors and 0,4 $\mathrm{A}$ NilC-extrated recepters from nuelei. It wals concluded that there is no nel cliange in degree of phissplorylitlion between non-ltimsformed receptor and receptor latusformed to the tight nucicitr hinding form). This is antolngous to resulis ohtained for the glacocorticoid receptor in motase $\mathrm{L}$ cells $\{23]$ and W W.1II.7 cels |24\}.

Since our methosds nnis meitsure the tostat imount of phosphate issesciated wilh the receptor, it is still pussible that these

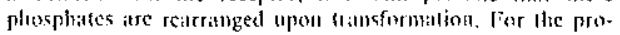
gesterone reeptor in T47D eclls, il has been shown lhat horere ate at least wo diflecent pirosplopeptides in (he trats sformed nucleat recepter, compared with the eylosolic non-11:tnstormed recepter

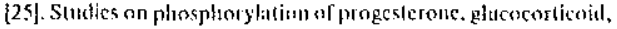

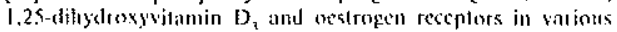
sysicms provieled evidence for hermone-dependent calat plosphinatiation $\{6,12,\{4,26-2$ ' $\}$.

Also in the present straly, using double latolling with $\left.\right|^{n}{ }^{2} P \mid P_{1}$

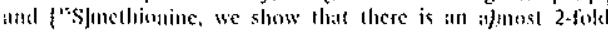

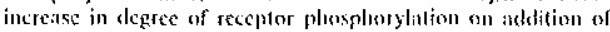

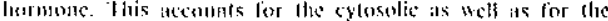

nutcicar-extractable anörogen receptor. This hormone-induced cxtsa phosphorylation is a rapid process, reaching an optimum within 3.9 min. The hatr-tife of the atudrogen receptor in LNCap cells is $2 \% 3 \mathrm{~h}$. in the presence as wctl as in the ahsence of ligant [16.30]. Only ifter longer incubations of LNCaP cells with androgens $24 \mathrm{~h}$ or longer could a significant increase of indfogen receptor protein be detected [31]. A possible slahilizing effect of andsogens on receptor protein, mintocking receptos hyperplosphoryiation, as recently shown for the indrogen recepior in COS cells [32], can thesefote be excluded.

Figure 5 presents a model for the location of phosphotylittion sitcs with respect to the finclional domains of the androgen receptor. It is possthe that, when the receptor is cleaved by a proleatse, cerlain fragments become more sensitive to dephoş̧forylation, thereby giving the faise impression that a certain fragment is not glinspleorylated. Hotsever, digestious were carries out with immunoadsorbed receptor, which had been

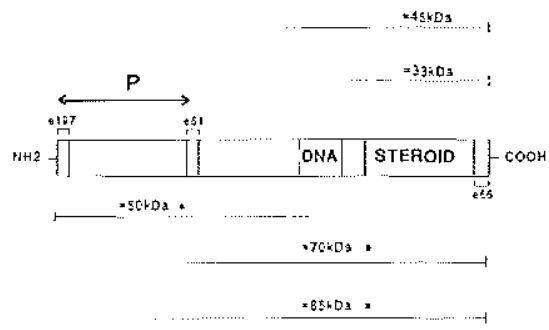

Figure 5 Model of phosphorylated region and funclional domains of the humian aAdrogen receptor

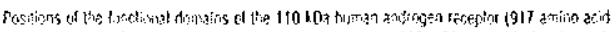

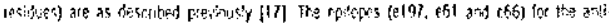

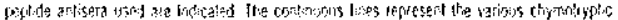

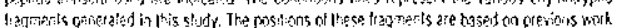

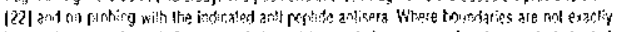

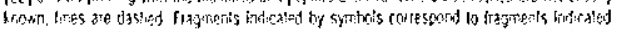

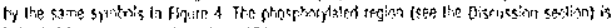
inst: at? 
llwornghly washof free of cellular constituenls, and we regard (his possifility as highly unlikely. The clymmetrytic frigments of $245 \mathrm{kD} ; \mathrm{a}$ (Figme 3) and $-50 \mathrm{kDa}$ (Figure 4) react with polyclonit antibodies directed against the $\mathrm{C}^{-}$and $\mathrm{N}$-teminus respeclisely. The possibilicy of missing phosphorylatesl sites in bolh termini can therefore be excluted. The predominant locilization of phosplorylation siles in the N-terminal domain of the amtrogen receptor is consistent with reperts on $\mathrm{nro}$ gesterane and glucocorticoid reseptors [R-12]. Recently seven pluesplorylited siles were identificel in the N-leminus

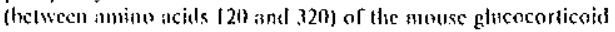
secenter [13]. Aks, ifter transfection of progesternie [3.3] and glecocorticovid [12] teceptors into COS or CV-I cells, it was shown thit all phosphorylated sites were located in the $N$ terminal demiain.

It is notcworthy that the region shown to be heavily phosphorylated (anino acid residues $J-300$ ) has also becn sitown In be essential for transcriptinnal activation [17]. A detetion mutsut lacking anvino acids $5 f-211$ ( $p \wedge R 7$ ) slowed a slrongly decreased transcriptional activation capacity, which was only $5 "$ of that of the wild-type androgen recepter. The will-lype androgen receplor expressed in cOS-1 cells migrated as a $110-112 \mathrm{kD}$ a douthlet when analysed hy S1DS/PAGE. This dnublet represcfits androgen-recentor isoforms produced by phosphorytation [15, 17,30]. The defetion mutant nAR7, however, migrated as a single hand witl an apparent molecular mass of $\sim 84 \mathrm{kDa}$ after expression in COS cells [17]. It is tempting to speculate that in the deleted region one or more serine or threntine residues hecome phosphorylated in the wifd-type ind frogen receptor, giving rise to the described toublet.

A possible mechasisu hy which phosphorylation might modulate tfanscription is by altering the transcriptional aclivition notential of a transcription factor. Evidcnce for this lype of regulation has heen provisled by studies in which a correlation wiss fotund between the plosphorylation state of certatin transcription fictors and their ithifity to activate Iranscription, despite phosphorylation inving no effect on line ability of these fuctors to bind to DNA [14]. Stch a model could atso he applied to members of the steroid-seceptor superfamily. No definitise evidence has heen provided so fits that phosphorylation of sleroid recepters directly influences DNA binding capacity [2] Also, in the present stukly we kate shown that there is no net change in the degree of receptor phosphorytation upon transformition in the intact cefl.

The mose definitise indication for a role of phosplorylation in regulating members of the receplos superfanily of tratuscription factors thas been mrovided for the progesterone receptor and the $\forall$ - rh A protein [35, 36]. It wis stomsn by site-directed mutagchesis that phosplinrylation of a particular serine restuse in the $N$. terminal part of $v$ erh $A$ regulates biological acdivity, without affecting nuclear localizattion or DNA-binding capacity [3S\}. The progesterone receptor in the chicken oviducl is a phosplioprotein, and trealment with pogesterone in rist stimulistes phosphorylation of the receptor [14]. In CV-I cells Irinsfecled wilf the chicken progesteronc receptor, it wits slonw'n that treatment of cells will kinase activutors or plosphatase inhibitors minicked progestcrone-dependent receptor-mediated transcription in the absence of progestcrone [36]. This suggested thit phosphorylation of the progesterone recepter or ollier proleins in the transcription complex morlulate progeslerone-receptormediated transeription.

The N-termintit receptor region definct here to the pratomimantly plosplorylated in the LNCal'-cell androgen receptor contains a total of 12 palentiat plinsphorylation siles for Ser-Pro-directed kinase, ciscin kinases and double-slatmuled-
DNA-depentenm kinase, on the basis of mublished comsensus sequences [37]. Idenlification of the actuil sites of phosphorylation strould allow slefinitive delermination of the role of plosphorylation in the mode of aclion of the androgen receptor.

This work was supnoteri by the Netherlands Organizaling for Selentitic flesearch

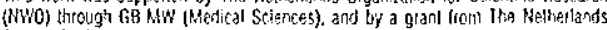
Cancet Soxtaly.

\section{BEFERENCES}

1 Besion, 14 (1959) Ct: 56. 335-344

2 Moudgl. V.K (1990) Biochim Eiophys Ada 1055. 243-258

3 Hossey, P, R and Fia!I, W. B (19R3) J Einl Chiem 258. 46.30-4\$35

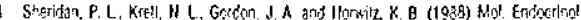
2. 1329-1342

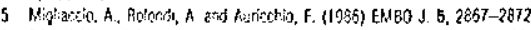

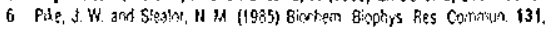
$378-3 \hat{85}$

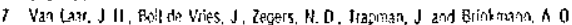

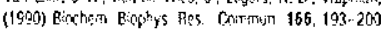

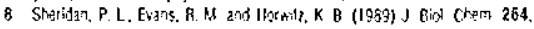
$6520-6528$

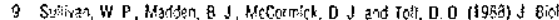
Che? 263. $14717-14723$

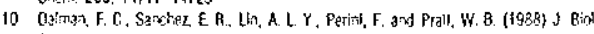
Chen 263. 12259-1226?

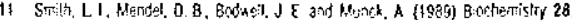
4190- $\$ 998$

12 Howh, W. and Ginter, 8 (1990) J. Bint chem 265. 5403-5408

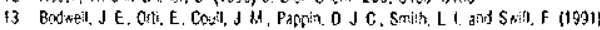

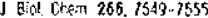

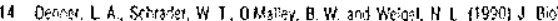
Chan 265 16548-16555

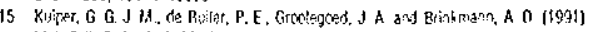
Whot Cefl Estominol 80, 65-73

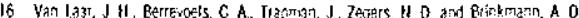
(1931) J Bind Chẹm, 266, 3734-3/23

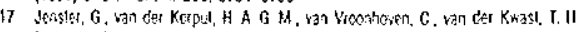

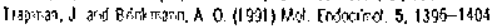

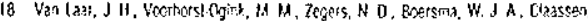

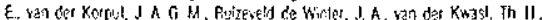

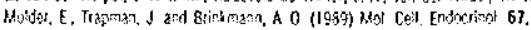
23-38

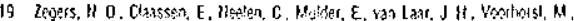

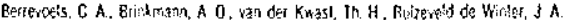

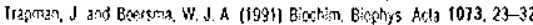

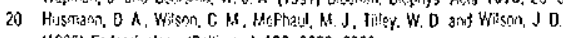

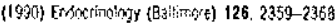

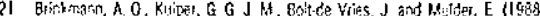
J. Stersid Bingtem 30. 257-261

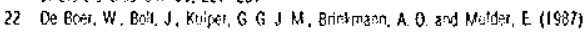
J. Stertid bicktem 28, 9-19

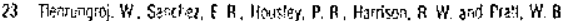
(1991) J Bial Chem 282, 17342-17369

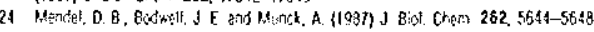

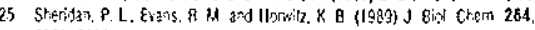
$6520-6528$

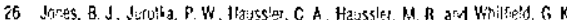
(1991) Mol Enderion 5. 1137-1145

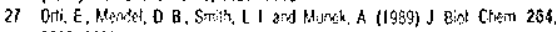
$9728-9731$

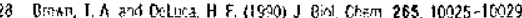

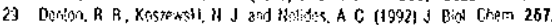
126?-7268

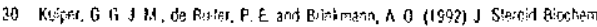
Mol Bint $41,677-700$

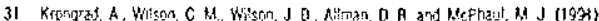
Hol Celt Emocting 76, 79-83

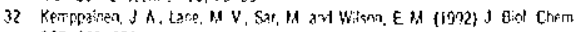
267. 958-974 


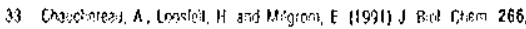
$182 B O-182 \hat{B} 5$

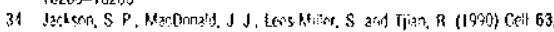
155.165

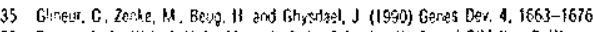

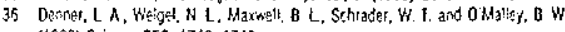
(1990) Scierce 250, 1740-1743

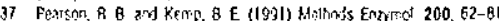

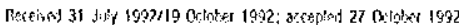




\section{CHAPTER 5}

\section{PHOSPHOTRYPTIC PEPTIDE ANALYSIS OF THE HUMAN ANDROGEN RECEPTOR: DETECTION OF A HORMONE-INDUCED PHOSPHOPEPTIDE}

George G.J.M. Kuiper and Albert O. Brinkmann

Biochemistry, (1995) $\underline{34}$, in press. 


\title{
Phosphotryptic Peptide Analysis of the Human Androgen Receptor: Detection of a Hormone-Induced Phosphopeptide ${ }^{\dagger}$
}

\author{
George G. J. M. Kuiper*t and AJbert O. Brinkmann \\ Deparment of Endocrinology and Reproduction Faculty of Medicine and Hcalh Sciences, Erasmus University Rotterdam. \\ P. O. Box 173R, 3000 DR Rotterdam, The Netherlands
}

Received June 13, 1994; Revised Manuscript Receired September 26, $1994^{\circ}$

\begin{abstract}
Phosphorylation of the androgen receptor (AR) in human prostate tumor cells (LNCaP) is increased by androgens. The AR is expressed as two isoforms with apparent molecular masses of 110 and $112 \mathrm{kDa}$. Metabolic labeling experiments with [ $\left.{ }^{32} \mathrm{P}\right]$ rthophosphate revealed that only the $112 \mathrm{kDa}$ isoform is radioactively labeled. Phosphoanino acid analysis revealed only phosphorylation on serine residues. Phosphotryptic peptide analysis of human AR protein by two-dimensional peptide mapping and by reverse-phase HPLC showed phosphorylation at multiple sites. Comparison of phosphopeptide maps of AR protein from cells incubated in the absence or presence of the synthetic androgen R1881 indicated that the ligand-stimulated phosphorylation is probably due to induction of phosphorylation at a new site rather than increased phosphorylation at an existing site. This result suggests that hormonedependent AR phosphorylation might play a role in the signal transduction pathway of androgens.
\end{abstract}

Steroid hormone receptors are transacting gene-regulatory proteins, involved in the accomplishanent of steroid hormoneinduced cellular responses. Upon binding of hormone, the receptor hormone complex undergoes a conformational change called transformation, which is thought to precede binding of the receptor to homone-responsive elements in the target cell genome (Bagchi et al, 1992; Jensen, 1991).

Ample evidence has been provided that the progesterone, glucocorticoid, estrogen, androgen, and 1,25-dihydroxyvitamin D, receplors are phosphoproteins (Moudgil, 1990; Orti et al, 1992; Kuiper \& Brinkmann, 1994). Additional phosphorylation has been observed upon hornone binding. All steroid receptors investigated thus far have multiple phosphorylation siles (Moudgil, 1990; Orti et al., 1992). Steroid hormone receptor phosplyorylation has been directiy implicated in activation of homone binding capacity, nuclear-cytoplasmic shutling of steroid receptors, modula. tion of binding to hommone response elements, and regulation of receptor transactivation function (Takimoto \& Horwitz, 1993; Kuiner \& Brinkmann, 1994).

Previously we have studied androgen receptor (AR) ${ }^{1}$ synthesis and heterogeneity in the hunzan LNCaP cell line (Van Laar et al., 1990; Kuiper et al., 1991). In these cclls, the $A R$ is synthesized as a protein with an apparent molecular mass of $110 \mathrm{kDa}$, which becomes rapidly phosphorylated,

'This study was supported by The Netherlands Organization for Scfentific Research (NWO) through Gn-MIV (Niedical Sciences), and by The Nelherlands Cancer Socicly.

tPresent address: Center for Biolechnology, CBT, Novum, \$.14157 Iluddinge, Sweden. Fax: 46.8-7745538.

\& Abstract published in Adrance ACS Absiracts, December 1. 1994.

1 Abbreviations: TFA, trifluososcetic acid; SDS, sodium dodecy] sulfate; PAGE, polyacrylamide gel electrophoresis; DTT, dithothreitol; $H P L C$, high-performance liquid chromalography; $A R$, androgen receptor; LNCaP, Iymph node catcinomn of the prosiale; MEN, minimum essential medium; TPCK, N-tosyl-L-phenylalanine chloromethyl kelone; TLCK, $N$-losyl-l.-lysine chloromethyl ketone; R188I, 17 $\beta$-hydroxy. 17(n-methyl-4,9,1 l-estratrien-3-nne; DOC, sodium deoxycholate; PMSF, phenylmcthanesulfonyl fluoride; BSA, bovine senum altumin; TCA, isichloroacetic acid. resulting in an upshift to $112 \mathrm{kDa}$ on SDS-PAGB (Kuiper et al., 1991). In addition, metabolic labeling experiments using $\left[{ }^{32} \mathrm{P}\right] \mathrm{P}_{1}$ indicated that the $A R$ is a phosphoprotein in homone-depleted LNCaP cells, and also in COS cells after transfection with an $A R$ expression vector (Van Laar et al., 1990; Kemppainen et al., 1992). Upon addition of hormone to LNCaP cells, a rapid 2-fold increase in AR phosphory. lation degree was observed (Van Laar et al., 1991; Kuiper et al., 1993). Partial proteolysis of AR protein labeled with $\left.{ }^{32} \mathrm{P}\right] \mathrm{P}$, revealed that phosphorylation occurs mainly in the N-terminal transactivation domain (Kuiper et al., 1993). Also progesterone, glucocorticoid, and estrogen receptors are predominantly phosphorylated in the $\mathrm{N}$-terminal transcription activation domain, suggesting that phosphorylation might play a role in regulation of receptor transactivation function (Orti et al., 1992; Kuiper \& Brinkmann, 1994).

The N-terminal region of the AR, found to be predoninantly phosphorylated, contains 12 potential phosphorylation sites for Ser/Thr-Pro-directed kinases, casein kinases, and double-stranded DNA-dependent kinase, on the basis of published consensus sequences (Kenneily \& Krebs, 1991 ; Finnie et al., 1993; Kuiper et al., 1993). These kinases have been shown to phosphorylate various transcription factors and are supposed to be involved in the regutation of transcription factor activity (Hunter \& Karin, 1992). No data are available on the number of AR phosphorylation sites, their regulation by hormone, and the kinases involved. In the present study, we have used monoclonal antibodies against the AR to purify receptor protein from total cell lysates of LNCaP cells, after metabolic labeling with [ $\left.{ }^{32} \mathrm{P}\right]-$ $P_{i}$. The purifted AR protein was digested with trypsin, to estimate the number of phosphorylation sites and the effect of homme incubation on the various sites. The resulting phosphopeptides were resolved by 2D phosphopeptide mapping and by reverse-phase HPLC. It is described herein that the AR contains multiple phosphorylation sites and that a new phosphopeptide is detectable upon homone treatment, indicating the induction of phosphorylation at a site which 
is not phosphorylated in AR from cells incubated in the absence of hormone.

\section{MATERIALS AND METHODS}

Materials. $\left[{ }^{35} \mathrm{~S}\right]$ Methionine ( $\left.>1000 \mathrm{Ci} / \mathrm{mnol}\right)$ and $\left[{ }^{32} \mathrm{P}\right]-$ orthophosphate (carrier free) were obtained from Amersham (Little Chalfont, Bucks, U,K.). Cutture media were obtained from Gibco (Life Technologies, Breda, The Netherlands) The synthetic androgen $17 \beta$-hydroxy-17a-methyl-4,9,11estratrien-3-one (R1881) was purchased from NEN-Dupont ('s Hertogentrosch, The Netherlands). The monoclonal antibody against the AR (F39.4.1, epitope amino acid residues $301-320$ ) and the polyclonal antiserum sp061 have been described previously (Van Laar et al., 1989, 1990). Trypsin (TPCK-treated) was from Sigma (St. Louis, MO), and bovine $\alpha$-chymotrypsin was from Merck (Datmstadt, Germany). Sequencing-grade endoproteinase Glu-C (V8 protease) and 'TLCK (trypsin inhibitor) were oblained from Boefringer Mannhein (Germany). Thin-layer cellulose plates and all solvents for $2 \mathrm{D}$ phosphopeptide mapping were obtained from Merck. HPLC reagents were from Merck, and from J. T. Baker Chenical Co. (Phitlipsburg, NY), All other chemicals and reagents were from commercial sources and high purity.

Cell Culure. The LNCaP cell line was cultured as described previously (Van Laar et al., 1991). LnCaP cells between the 66th and $741 \mathrm{t}$ passage in vitro were used for the present studies.

Metabolic Labeling. For phosphorylation studies, LNCaP cells were incubated for $12-16 \mathrm{~h}$ at $37^{\circ} \mathrm{C}$ in phosphatefree $\mathrm{MEM}$ (Signa) with $0.25 \mathrm{mCi} / \mathrm{mL}\left[{ }^{32} \mathrm{P}\right.$ ]orthophosphate, in the presence or absence of $10 \mathrm{nM} \mathrm{R} 1881$. Each $175 \mathrm{~cm}^{2}$ flask contained about $7 \times 10^{7}$ cells in $10 \mathrm{~mL}$ of medium, and was kept in a humidified atmosphere of $5 \% \mathrm{CO}_{2}$ in air. For labeling with $\left[{ }^{35}\right.$ S] methionine, $7 \times 10^{7} \mathrm{LNCaP}$ cells were incubated for $60 \mathrm{~min}$ at $37{ }^{\circ} \mathrm{C}$ with $20 \mu \mathrm{Cl} / \mathrm{mL}\left[{ }^{35} \mathrm{~S}\right.$ methionine in $5 \mathrm{~mL}$ of methionine-free RPMI 1640 medium. Incubations were stopped by removal of the medium, immediately followed by a wash with PBS at $20^{\circ} \mathrm{C}$.

Preparation of Cellular Lysates. Cells were lysed at $6-8$ ${ }^{\circ} \mathrm{C}$ with $1.5 \mathrm{~mL}$ per flask of lysis buffer [ $40 \mathrm{mM}$ Tris-HCI (pH 7.4), $5 \mathrm{mM}$ EDTA, $10 \mathrm{mM}$ sodium phosphate, $10 \mathrm{mM}$ DTT, $10 \%$ v/v glycerol, $10 \mathrm{mM}$ sodium molybdate, $50 \mathrm{mM}$ $\mathrm{NaF}, 0.5 \mathrm{mM}$ sodium orthovanadate, $1 \%$ Triton X-100, $0.5 \%$ w/v DOC, 0.08\% SDS, $0.6 \mathrm{mM}$ PMSF, and $0.5 \mathrm{mM}$ bacitraciti]. The lysate was cleared by centrifugation ( 30 min, $100000 \mathrm{~g}$ ) at $6^{\circ} \mathrm{C}$.

Immunoprecipitation and Gel Electrophoresis, Cell lysates were immunoprecipitated with anti-AR F39.4.1 monoclonal antibody linked to agarose beads (Van Laar et al., 1991). Typicaliy, $1.5 \mathrm{~mL}$ portions of lysate were incubated with $25 \mu \mathrm{L}$ (packed gel) of F39-agarose $(\sim \mathrm{f} \mu \mathrm{L}$ of F39 ascites) for 2 in at $4^{\circ} \mathrm{C}$ with gentle shaking. As a control, lysates were immunoprecipitated with anti-PSA (prostatespecific antigen) monoclonal antibody linked to agarose beads. The agarose beads were then washed extensively with delergent and salt-containing buffers, as described previously (Kuiper et al., 1991). Proteins were extracted with sample buffer [40 mM Tris-HCl (pH 6.8), 5\% (v/v) glycerol, $2 \%$ (w/v) SDS, and $10 \mathrm{mM}$ DTT], boiled for $3 \mathrm{ntin}$, and centrifuged. The supernatants were separated on 7\% SDSPAGE gels in a mini Protean Il cell (Bio-Rad) and subsequently blotted to nitrocellulose as described previously (Kuiper et al., 1991). The nitroceltutose membrane was dried for 30 min or longer, and incubations with polyclonal AR antiserum sp061 and sccondary alkaline phosphalaseconjugated antibodies were done as described (Kuiper et al., 1991). The blot was air-dried and autoradiographed using Amersham Hyperfilm MP.

Generation of Phosphopeptides and Two-Dimensional Separation. Immunopurified receptors were separated on SDS-PAGE gels as described. The gels were washed with water and dried during $12 \mathrm{~h}$. Dried gels were autoradiographed, and the autoradiogram was used as a guide to excise AR protein. Dried gel slices containing ${ }^{32} \mathrm{P}+$ labeled $\Lambda \mathrm{R}$ (equivatent to one flaski see Metabolic Labeling) were reliydrated in $0.75 \mathrm{~mL}$ of $50 \mathrm{mM} \mathrm{NH} \mathrm{HCO}_{3}$ (pH 8.0) and incubated for $16 \mathrm{~h}$ at $37^{\circ} \mathrm{C}$ with $50 \mu \mathrm{g}$ of TPCK-treated trypsin. Three more additions of $25 \mu \mathrm{g}$ of trypsin each were made with $6-12 \mathrm{~h}$ intervals. The fractions were combined and tyophilized, For two-dimensional separation, tryptic phosphopeptides were separated first on thin-layer cellulose plates, by electrophoresis at $500 \mathrm{~V}$ for 45 min at room temperature in $1 \%$ w/v ammonium carbonate buffer (pH 9.1) in a chamber as described by Gracy et al. (1977). After drying, chromatography in the second dimension was done for $6-8 \mathrm{~h}$ at room temperature in butanol/isobutyric acid/ pyridine/glacial acetic acid/water (2:65:5:3:29) (Scheidtnann et al., 1982). Plates were dried and subjected to autoradiography for $3-5$ weeks at $-70^{\circ} \mathrm{C}$.

MPLC Analysis. Immunopurified AR proteins from five to seyen flasks of LNCaP cells (total $10-15 \mathrm{mCl}$ of $\left[{ }^{32} \mathrm{P}\right]$. orthophosphate) were separated on SDS-PAGE gels and treated with trypsin as described. After lyophilization, the phosphopeptides were taken up in $30 \mu \mathrm{L}$ of $0.1 \%$ TFA. Peptides were separated by reverse-phase HPLC using a 2 $\times 150 \mathrm{~mm}$ Waters Delta Pak C18 column (Waters Chro. matography Division, Millipore Corp., Milford, MA). The HPLC equipment consisted of a Waters 62SLC system with a $600 \mathrm{E}$ systern controllet and a Waters 486 UV detector. The sample $(25 \mu \mathrm{L})$ was applied on the column in $0.1 \%$ TFA, and a linear gradient of $0-60 \%$ acetonitrile in $0.1 \%$ TFA was generated in $240 \mathrm{~min}$. The flow rate was $0.18 \mathrm{~mL} /$ min, and fractions were collected every $1.5 \mathrm{~min}$ with an ISCO Retriever Il fraction collector. Radioactivity of the fractions was determined by Cerenkov counting in a Packard 2500 TR counter (approximately $30 \%$ efficiency).

Phosphoamino Acid Analysis, Inımunopurified AR protein was eluted from the $F 39 \mathrm{mAb}-$ agarose beads with $0.75 \mathrm{~mL}$ of buffer $\left[50 \mathrm{mM} \mathrm{NH}_{4} \mathrm{HCO}_{3}(\mathrm{pH} 8.0) / 0.1 \%\right.$ SDS/ $10 \mathrm{mM}$ DTT] for 3 min at $90{ }^{\circ} \mathrm{C}$. After addition of $100 \mu \mathrm{g}$ of BSA as carrier protein, precipitation occured with $20 \% \mathrm{w} / v$ TCA on ice. The precipitate was dissolved in $100 \mu \mathrm{L}$ of $6 \mathrm{~N}$ ultrapure $\mathrm{HCl}$ (Pierce Chemical Co., Rockford, IL) and hydrolyzed for $1 \mathrm{~h}$ at $110^{\circ} \mathrm{C}$. After repeated jyophilization steps, the sample was resuspended in $10 \mu \mathrm{L}$ of bidest containing $2 \mathrm{mg} / \mathrm{mL}$ phosphoamino acid standards each (Sigma) and spolted on a cellulose thin-layer plate. Twodimensional electrophoretic separation of the partial hydrotysis products was done at $\mathrm{pH} 1.9$ in formic acid/acetic acid/ bidest (50:156:1794), and at pH 3.5 in acetic acid/pyridinel bidest (100:10:1890), for 90 min at $500 \mathrm{~V}$ in each dimension (van der Geer et al, 1993). Plates were autoradiographed for $1-2$ weeks at $-70^{\circ} \mathrm{C}$. 


\section{Rinchenitstry}

Sinichiometry of Phosphorylation. These experiments were performed as described for pp60.ss and plospholipase C- $\gamma$ (Meisenbelder et al., 1989; Sefton et al., 1982; Sefton, 1991). In brief, $(2-3) \times 10^{3}$ LNCaP cells were incubated for $24 \mathrm{~h}$ in $11 \mathrm{~mL}$ of a mixture of methionine-free and phosplate-free MEM/phosphate-free MEM (80;20), supplemented with $\mathrm{NaH}_{2} \mathrm{PO}_{4} \cdot \mathrm{H}_{2} \mathrm{O}$ to a final concentration of 0.95 nM. To this medium was added either approximately 100 $\mu \mathrm{Ci}$ of $\left[{ }^{3} \mathrm{~S}\right]$ methionine or $4 \mathrm{mCi}$ of $\left[{ }^{32} \mathrm{P}\right]$ orthophosphate. The specific activity of the phosphate in the medium was calculated from the measured amonnt of ${ }^{32} \mathrm{P}$ in the medium at the end of the incubation and the known amount of phosphate. Cells were lysed at $6-8^{\circ} \mathrm{C}$, and the AR protein was immunoprecipitated as described and separated on a $7 \%$ SDS-PAGE gel. Following autoradiography, either the ${ }^{35} \mathrm{~S}$ or the ${ }^{32} \mathrm{p}$-labeled $A R$ bands were cut out from the dried gel and solubilized with Soluene (Packard) at $60^{\circ} \mathrm{C}$ for $4 \mathrm{~h}$ before being counted in scintillation fiuid. Total cellular protein was measured in a sample of the lysate by the Bradford dye method, using BSA as standard (Rubin \& Warren, 1977). The radioactivity ("'S) of the cellular protein was measured in a fraction of the lysate, by $\mathrm{TC} \Lambda$ precipitation of protein onto a glass fiber filter which was counted in parallel with the "S-labeled gel bands.

\section{RESULTS}

Andragen Receptor Protein Heterogeneity and Phosphorlation. Pulse-labeling studies with [ $\left[{ }^{3}\right.$ S $]$ methionine showed that the $\mathrm{AR}$ is syntlesized as a $100 \mathrm{kDa}$ protein which is rapidly converted to a $112 \mathrm{kDa}$ protein. Alkaline phosphatase tratment of cytosols either from LNCaP cells or from $C O S$ cells transiently expressing $A R$ protein caused an elimination of the $112 \mathrm{kD}$ a isoform with a concomitant increase of the $110 \mathrm{kDa}$ isoform (Kuiper et al., 1991; G. Jetster et al., submitted for publication). These experiments indicated that the $112 \mathrm{kDa} A R$ isnform is phosphorylated, but did not provide information on the phosphorylation slatus of the $110 \mathrm{KDa} A R$ isoform. Therefore, LNCaP cells were metabolically labeled with [ ${ }^{35}$ S]methionine for $1 \mathrm{~h}$, and the AR protein was immunoextracted and separated on SDSPAGE gels. The autoradiogram as well as the immunoblot showed an AR doublet of 110-112 kDa molecular mass, indicating that de novo synthesized as well as preexisting AR proteins exist as two isoforms in LNCaP cells (Figure 1 , lanes 2 and 4). In a similar experiment, LNCaP cells were metabolicaliy labeled witla ${ }^{32}$ P)othophosplate for $16 \mathrm{~h}$. The half-life of the AR protein in LNCaP cells is between 2 and $3 \mathrm{~h}$, allowing the turnover of essentially all $A R$ molecules during 16 h incubation (Van Laar et al., 1991). The autorationgram (Figure 1, lane 6) showed only one radioactively labeled band, comigrating with the 112 kDa $A R$ isofotm. Also after incubation of cells with $10 \mathrm{nM}$ of the synthetic androgen R1881, only the $\mathrm{t} 12 \mathrm{kDa}$ band was tadinactively labeled (Figure 1, lane 7). From this experiment, we concluded that the $112 \mathrm{kDa}$ AR isoform sepresents phosphorylated $A R$ and that the $110 \mathrm{kDa} A R$ isoform represents nonphosphorylated AR protein. From the immunoblots (Irigure 1, lanes 1 and 2), it is not possible to calculate the ratio between both $A R$ isoforms.

In an attempt to determine the extent to which AR protein is phosphorylated in LNCaP cells, we labeled cells for $24 \mathrm{~h}$ with either [ "S]methionine or ["2P]othophosphate, and isolated $A R$ protein by immunoprecipitation and SDS-
Phosphorylation of the Human Androgen Receptor

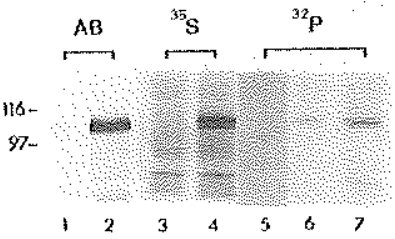

Figure 1: AR prolein hetetogeneity and phosphorytation. LNCaP cells were incubated for $16 \mathrm{~h}$ with [32 $^{32}$ Jorthophosphatc (lanes 5, 6 , and 7), is the presence (lane 7) or absence (lanes 5 and 6) of 10 nM R1881. Another set of cells was incubated with (35) 3 methionine for i h (lanes 1-4). Receptors immunoprecipitated from total cell lysates with the F39 monoclonal antibody (lanes $2,4,6$, and 7) or nonspecific mouse IgG (lanes 1, 3, and 5). Afler SDS-PAGE on a $7 \% \mathrm{gel}$, the proteins were transferred to a nitrocellulose membrane and incubated with polyclonal $\mathrm{AR}$ antisentm sn061 and secondary alkaline phosphatase-conjugated antibodles (AB), as described (lanes 1 and 2). The gels prepared from the LNCaP cells incubated with ["'S]methionine (lames 3 and 4 ) or $\left[{ }^{32}\right.$ P]orthophosphate (lanes $5-7)$ werc autoradiogranted. Molecular nass markers (kDa) are indicated on the left.

\begin{tabular}{|c|c|c|c|c|c|}
\hline & \multicolumn{4}{|c|}{ flask } & \multirow[b]{2}{*}{$x \pm s D^{x}$} \\
\hline & 1 & 2 & 3 & 4 & \\
\hline $\begin{array}{l}\text { "P (cpm) } \\
" \text { PA SA (cpm/pmol) }\end{array}$ & $\begin{array}{l}1180 \\
660\end{array}$ & $\begin{array}{l}1058 \\
659\end{array}$ & $\begin{array}{l}894 \\
614\end{array}$ & & \\
\hline $\begin{array}{l}P \text { in AR (pmol) } \\
\text { ss } S(d p m)\end{array}$ & & & $\begin{array}{l}1.46 \\
666\end{array}$ & 431 & $1.62 \pm 0.16(n=3)$ \\
\hline${ }^{31} \mathrm{SSA}^{\circ}(\mathrm{dpm} / / \mathrm{gg})$ & 2790 & 3022 & 2982 & 3216 & \\
\hline $\mathrm{AR}^{c}(\mathrm{pmol})$ & 1.18 & 1.62 & 2.28 & 1.37 & $1.61 \pm 0.47(n=4)$ \\
\hline \multicolumn{6}{|c|}{ 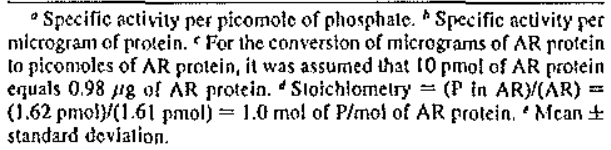 } \\
\hline
\end{tabular}

PAGE. The number of moles of phosphate incorporated per mole of AR protein was calculated, with the assumptions that (1) after 24 b the specific activity of the phosphoamino acids in AR protein is the same as that of the plosphate in the labeling medium and that (2) the specific activity of the methionine in AR protein is the same as that in bulk cellular protzin (see Materials and Methods). It was calculated that the AR protein contains $1.0 \mathrm{~mol}$ of phosphate per mole of protein $(n=3)$ when the LNCaP cells were not incubated with R188I (see Table 1). Since only an aggregate value was measured, we cannot calculate exactly which fraction of the total population of $A R$ molecules is phosphorylated. Since also after R 1881 incubation of LNCaP cells the AR protein is detected as a $110-112 \mathrm{kDa}$ doublet on immunoblots (Kuiper et al., 1991), we conclude that a significant fraction of AR molecules remains nonphosphorylated (110 $\mathrm{kDa}$ isoform) in the presence of hormone.

Phosphoamino Acid Analysis of AR Protein. In order to obtain some information on the type of kinases which phosphorylate human AR protein, we analyzed the phosphoamino acids of $A R$ protein isolated from $\mathrm{LNCaP}$ cells incubated in the presence or absence of R188I. Conditions of acid hydrolysis $(1 \mathrm{~h})$ were optimal for the preservation of phosphoamino acids, especially phosphotyrosine (Duclos et al, 1991). After (wo-timensional electrophoresis of the acid hydrolysate of immunopurified AR protein from cells incubated with $10 \mathrm{nM}$ R 1881, only phosphorytation on serine 


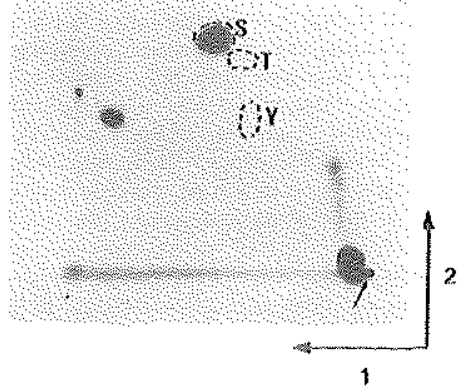

Fioure 2: Phosphoantino acid analysis of AR protcin. LNCaP cells wese incubated for $16 \mathrm{~h}$ with $\left[{ }^{32}\right.$ P] subscquently AR protein was immunopurified as described under Materials and Mcthods. The "2p.labeled AR protein was subjected to partial actd hydrolysis $\left(6 \mathrm{~N} \mathrm{HCl}, \mathrm{I} \mathrm{h}\right.$ at $110^{\circ} \mathrm{C}$ ). Partial hydrolysis producls were mixed with untabeled phosphoamtno acid standards and resolved on thin-layer cellulose plates by electrophresis at pH 1.9 (first dimension, 1) prior to efectrophoresis at pH 3.5 (second dimension, 2), Unlabeled phosphoamino acids were visualized by ninhydrin staining and "2p-labeled phosphoamino acids by autoradiography. The position of the phosphoserine (S), phosphothreenine (T), and phospholyrosine $(Y)$ standards is indicated. The origin is indicated by a small arrow.

residues was observed (see Figure 2). During onedimensional electrophoresis, there was, apart from ${ }^{32} \mathrm{P}$ activity comigrating with the phosphoserine standard, also ${ }^{32} \mathrm{P}$ activity wholly or partially overlapping with the phosphotyrosine and phosphothreonine standards (result not shown). However, during $2 \mathrm{D}$ electrophoresis, this ${ }^{32} \mathrm{P}$ activity separated from the phosphotyrosine and ghosphothreonine standards (see Figute 2), and probably results from nucleosicte monophosphates, arising from RNA degradation during acid hydrolysis (Duclos et al., 1991). Also when AR protein was isolated from cells incubaled without $R 188 \mathrm{I}$, or after elution of intact AR protein from SDS-PAGE gels, only phosphorylation on serine residues was detected (not shown).

Peptide Analysis of the "P-Labeled Androgen Receptor, In previnus studies, it was shown that the phosphorylation degree of tlie AR protein in LNCaP cells increases 2-fold upon incubation of cells with $R 1881$ and that predominantly the $\mathrm{N}$-terminal domain is phosphorylated (Van Laat $\mathrm{ct}$ al., 1991; Kuiper et al., 1993). In order to obtain infomation on the nimber of AR phosphorylation sites and the effect of hormone treatment on individual sites, two-ditnensional phosphopeptide maps were prepared. Immunopurified and SDS-PAGE gel-purified ${ }^{32} \mathrm{P}$-labeled AR was digested with TPCK-treated trypsin (see Materials and Metlods), and the phosphopeptides were sep̧arated on thin-layer cel!ulose plates by electrophoresis in the first dinension and by chromatog. raphy in the second dimension. In initial studies, various buffers for electrophoresis and chromatography were used, and the maps obtained were analyzed. When electrophoresis was performed at $\mathrm{pH} 3.5$ or $\mathrm{pH} 1.9$, all the phosphopeptides remained at or neas the application site (results not shown). A possible explanation for this lack of mobility could be the fact that the $N$-terninal domain of the human $A R$ is very hydrophilic and contains a large number of acidic amino acid resikues, especially between amino acid residues 100 and 325 (Faber et al, 1989). When the $\mathrm{pH}$ of the electrophoresis buffer was raised to 9.1 , most phosphopeptides moved toward

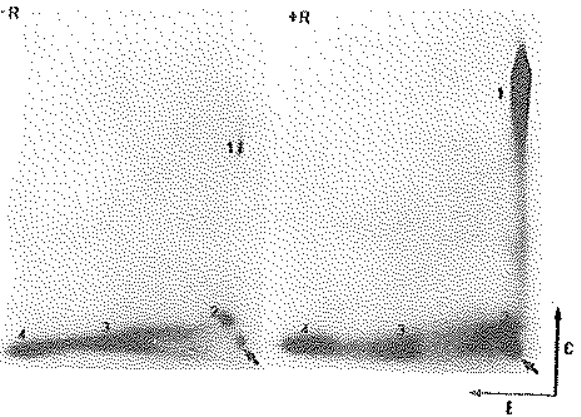

Figure 3: Two-dimensional phosphopeptide maps of trypsindigested AR prolein. AR protein was labeled in LNCaP cells with [32 $\mathrm{P}$ ]orthophosphate during an incubation for $12 \mathrm{~h}$, in the presence or absence of $10 \mathrm{nM}$ R 1881 , and subsequentiy immunoprecipitated frent tolal cell lysates. The proteins were resolved on a 7\% SDSPAGE gel (see Figure 1 , lanes 6 and 7 ), and phosphoproteins were detected by autoradiography of the dried get. The labeled AR protein was excised from the gel and digested with trypsin. Twodimensional maps of the phosphopeptides were prepared on thinlayer cellulose plates through clectrophotesis (E, anode on the left) and chromatogranhy (C), and described under Materiats and Methods. Shown are the autoradiograms ( 3 weeks exposure at -70 ${ }^{\circ} \mathrm{C}$ ) of AR protein from cells incubated in the presence of $10 \mathrm{nM}$ Ri881 (+R) or without R $1881(-R)$. The origins are indicaled by arrow's.

the anode, indicating the relative enrichment of acidic anino acid residues in these peptides (see Figure 3). Duting chromatography in "isobutyric acid buffer", designed to resolve hydrophilic phosphopeptides (Scheidtmann et al., 1982), only one phosphopeptide moved in the second dimension, showing that most AR phosphopeptides are extrenely hydrophilic (see Figure 3). In tolal, four phosphopeptides were identified, although it should be emphasized that the resolution of the hydrophilic peptides which do not move in the second dimension during chromatography is not optimal. In Figure 3, a comparison is shown between tryptic phosphopeptide maps of ${ }^{37} \mathrm{P}$-labeled AR protein isolated from cells incubated either in the presence or in the absence of $10 \mathrm{nM}$ R1881 (see also Figuse 1, lanes 6 and 7). The location and number of phosphopeptides were the same in each case. A significant increase in the phosphorylation degree of the peptides which are moving in the second dimension during chromatography, however, was observed after hormone treatment of the cells. No significant changes in the phospliorylation degree of the other peptides were detccted. The homone-induced phosphopeptide spot is very broad, possibly due to phosphorylation of the same peptide at different positions, which affects its hydrophobicity 10 different degrees due to the context of the phosphorylation site (Boyle et al., 1991).

Although the two-dimensionat thin-layer separation method was sensitive to quantitative changes in the phosphorylation degree of AR phosphopeptides, the resolution of most of the hydrophilic peptides was not optimal. Therefore, separa. tion of tryptic phosphopeptides by reverse-phase HPLC was performed. The peptides were generated by tryptic digestion of AR protein as described (Materials and Methods) and applied to a $\mathrm{C} 18$ column in $0.1 \%$ trifluoroacetic acid. A total of 15 separate ${ }^{32} \mathrm{P}$-labeled peaks above background $(20$ $\pm 2 \mathrm{cpm}$ ) were detecled (see Figure 4). This was clearly 


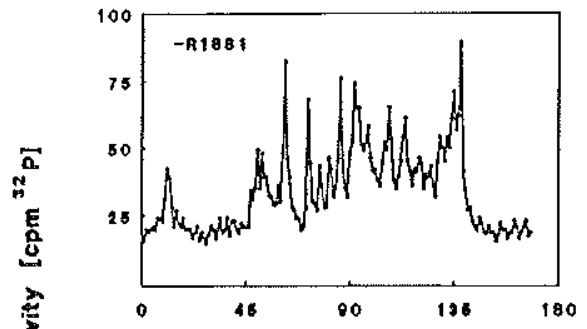

옳

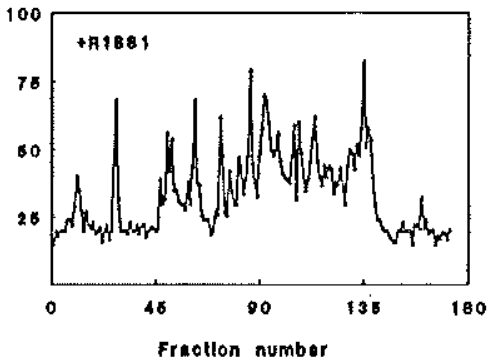

FIGURE, 4: HPLC elution profiles of tryplic phosphopeptides of AR ptotein from LNCaP cells. AR protein was labeled in LNCaP cells with ["Plorthophosphale during incubation for $12 \mathrm{~h}$ in the presence $(\Delta ;$ lower graph) or absence ( 6 ; upper graph) of 10 nst R 1881, and immunoprecipitated from total cell tysates. Following electrophoresis, the labeled AR protein was excised and digested with trypsin. The peptides were acidified and applied to a $\mathrm{Cl}$ column. The column was developed with a linear $0-60 \%$ acetonitrile gradient in $0.1 \%$ TFA, in 240 min. The flow' rale $\mathrm{H}^{\prime \prime 3}$ $0.18 \mathrm{~mL} / \mathrm{min}$, and fractions were collected every $1.5 \mathrm{~min}$. Ftactions were analyzed by Cerenkov counting.

more than the number of phosphopeptides detected by thinlayer separation (see Figure 3). Incubation of LNCaP cells with $\mathrm{R} \mid 881$ induced ptosphorylation of a site in a peptide eluting in fractions $27-28$ (retention time $40 \mathrm{~min}$ ). Only minimal differences in the phosplionylation degree and elution positions of the otler peptides were observed (Figure 4), indicating that the homone-stimulated AR protein hyperphosphorylation is to a large extent due to phosphorylation of a new site.

\section{DISCUSSION}

Steroid hormone receptors, including the $A R$, are heterogeneous proteins that exist as multiple isoforms, migrating as doublets or triplets on SDS-PAGE gels. Upon ligand binding, the isoforms of progesterone, androgen, estradiol, and vilamin $D$ receptors undergo an increase in appasant molecular mass, concomitantly with additionat phosphoryJation (Jurułka et al., 1993; Brown \& DeLuca, 1990; Le Golf et al., 1994; Wastburn et al., 1991; Beck et al., 1992; G. Jenster, personal communication). The reason for these mobitity shifts is not clear, since the actual increase in molecular mass of the protein by phosphorylation is very sinall. A discrepancy exisis between the theoretical calculated molecular mass of the AR protein $(98 \mathrm{kDa})$ and the appatent molecular mass on SDS-PAGE gels (110-112 $\mathrm{kDa}$ ). In the present study, it was shown that the nonphos- phorylated AR protein has an apparant molecular mass of $110 \mathrm{kDa}$, indicating that this discrepancy is not due to phosphorylation. In another study, this discrepancy has been ascribed to some unknown features of the region between amino acid residues 51 and 211 of the human $A R$ protein (Jenster et al, 1991). For the mouse glucocorticoid receptor, a similar discrepancy in molecular mass bas been ascribed to the region between amino acid residues 108-324 (Hutchison et al., 1993). The two regions have in common a relatively high content of acidic amino acid residues, which might influence in both cases the association of SDS and thereby the mobility during SDS-PAGE. An alternative posttranslational modification, such as glycosylation, causing anomalous behavior on SDS-PAGE gels, cannot be excluded.

In the present study, it was calculated that the $A R$ protein contains $1 \mathrm{~mol}$ of phosphate/mol of protein. The stoichiomelify measurements may be an underestimation, if the specific activity of the phosphoamino acids in the AR protein is not equal to that of the phosphate in the labeling medium or if cellular phosphatases are active during cell lysis. It was attempted to minimize these factors by labeling the cells for $24 \mathrm{~h}$ and by adding phosphatase inhibitors to the lysis buffer. Phosphorylation after cell lysis was blocked by the addition of EDTA and nonradioactive phosphate to the lysis buffer. Given the rapid turnover of phosphate groups on proteins, this renders the labeling of the phosphoryl moieties in phosphoproteins to equilibrium much easier than the labeling of the polypeptide backbone. The average halflife of cellular proteins $(40 \mathrm{~h})$ is long relative to the length of time that many kinds of cells can tolerate radiolytic damage (Weber, 1972; Sefton, 1991). On the other hand, the specific activity ( ${ }^{35}$ S $]$ methionine labeling) of a protcin with a stort hatf-life would be greater than that of bulk cellular protein if the labeling period was 100 short. The AR half-life is between 2 and $3 \mathrm{~h}$ (van Laar et al, 1991; Syms et al., 1985), so that after a labeling period of $24 \mathrm{~h}$ all $A R$ protein molecules have been renewed.

In the present investigation, it is show'n that the AR protein is exclusively phosphorylated on serine residues. Nuclear, but not cytosolic, AR protein from rat ventral prostate was shown previously to react with anti-phosphotyrosine antibodies, indicating that these receptors or associated protein(s) are possibly phosphorylated on tyrosine residues (Golsteyn et al., 1989; 1990). However, it should be noted that no intact $110 \mathrm{kDa} A \mathrm{R}$ protein was identified in these studies. Phosphoamino acid analysis has revealed that the glucocorticoid, progesterone, and 1,25 -dihydroxyvitamin $D_{3}$ receptors are phosphorylated on serine residues (Dalman et al., 1988; Sheridan et al., 1988; Brown \& DeLuca, 1991). Results on phosphoamino acid analysis of estrogen receptors are not conclusive. While Auricchio (1989) showed that estrogen receptors are only phosphorylated on tyrosine residues, other investigators reported phosphorylation only on serine residues (Washburn et al., 1991; Denton et al., 1992; LeGoff et al., 1994; Lahooti et al, 1994). Separation of tryptic phusphopeptides from human $A R$ protein revealed that the $A R$ is phosphorylated at multiple sites. When a comparison was made between cells inctibated with $R 1881$ and cells incubated without R1881, it was found that one additional phosphopeptide appeared after hormone treatment. No further signiftcant changes (quantitatively and/or qualitatively) were detected in the two separation systens which were used. 
It is difficult to give an accurate estimation on the number of AR protein phospherylation sites. The $N$-terninal region shown to be heavily phosphorylated in the $A R$ protein contains 33 serine residues and 12 consensus phosphorylation sites for casein kinases, Ser-Pro-directed kinases, and DNAdependent kinase. Partial trypsin digestion products can be generated at aljacent arginine and/or lysine residues and also at arginine/lysine-aspartic acid/glutamic acid bonds (Boyle ct al., 1991). Between amino acid residues $I$ and 300 of the AR protein, six of these combinations known to cause partial digests are present, so that it is possible that a single phosphorylation site gives rise to several different phospho. peptides. Nevertheless, from the present results, it can be inferred that the number of AR phosphorylation sites is in the same otder as those reported for the glucocorticoid and progesterone receptors. In the mouse glucocorticoid receptor, seven phosphorylation sites were identified, and in the chicken progesterone receptor, four sites were foind (Poletti \& Weigel, 1993; Bodwell et al., 1991; Poletti et al., 1993). Digestion of AR protein with a-chymotrypsin produced seven phosphopeptides after HPLC (result not shown). Digestions with V8 protease were not conclusive. The appearance of new phosphopeptides after homno treatment was also shown by phosphopeptide mapping for the human and chicken progesterone receptor, the calf uterus estrogen receptor, and the rat glucocorticoid receptor (Denner et al, 1990; Sheridan et al., 1989; Nakao et al., 1992; Denton et al., 1992; DeFranco et al., 1991). In contrast, for the human estrogen receptor and the avian progesterone receptor, it was found that hormone-induced phosphorylation was not due to phosphorylation at a new site, but rather incteased phosphorylation of existing sites (Sullivan et al., 1988; L.eGoff et al., 1994).

Efforts will now be focused on the identification of the hormone-stimulated AR phosphorylation site(s), in order to be able to identify their significance in nuclear cytoplasmic $A R$ shuttling, DNA binding of the AR protein, and transcriptional activation by the AR. Since the amount of $A R$ protein which can be purified from LNCaP cells is rather limited, this will involve the use of an AR protein overexpression system in yeast cells or insect cells.

\section{ACKNOWLEDGMENT}

We thank Mr. M. Edixhoven, Mr. Th. Hoogenboezem, and Dr. H. R. de Jonge for helpful suggestions, Mrs. P. E, de Ruiter for technical assistance, and Dr. J. A. Grootegoed for belpful discussions and for teading the manuscript.

\section{REFERENCES}

Auricclio, F. (1989) J. Stersid. Biochem, 32, 613-622.

Bagchi, M. K., Tsai, M. J., O'Malley, B. W., \& Tsai, S. Y. (1992) Endocr. Rev. 13, 525-535.

Beck, C. A., Weigel, N. L., \& Edwards, D. P. (1992) $\mathrm{Mol}$. Endocrinol. 6, 607-620.

Boúsell, J. E., Orti, E., Coull, J. M., Pappin, D. J. C., Strith, L. l., \& Swift, F. (199l) J. Biol, Chemt. 266, 7549-7555.

Boyle, W. J., Van der Geer, P., \& Hunter, T. (1991) Methods Enzynol. 201, 110-149.

Brown, T, A., \& DeLuca, H. F. (1990) J. Biol. Chem. 265, 10025- 10029.

Brown, T, A., \& DeLuco, If. F. (1991) Arch. Bincliem. Biophys. $286,466-472$.
Dalman, F. C., Sanchez, E. R., Lin, A. L. Y., Perini, F., \& Pratt, W. B. (1988) J. Biol, Chem. 263, 12259-12267.

De Franco, D. B., Ming Qi, Borrer, K. C., Garabedian, M. J., \& Brautigan, D. L. (1991) Mol. Endocrinol. 5, 1215-1227,

Denner, L. A., Schrader, W. T., O'Malley, B. W., \& Weiget, N. L. (1990) J. Biol. Chem. 265, 16548-16555.

Denton, R. R., Koszewski, N. J., \& Notides, A. C. (1992) J. Biol. Chem. 267, 7263-7268.

Duclos, B., Marcandier, S., \& Cozzone, A. J. (1991) Methods Enzymol. 201, 10-21.

Faber, P. W., Kuiper, G. G. J. M., Van Rooij, H. C. J., Van der Korput, J. A. G. M., Brinkniann, A. O., \& Trapman, J. (1989) Mol. Cell. Endocrinol. 61, 257-262.

Finnie, N., Gottlieb, T., Hartley, K., \& Jackson, S. P. (1993) Biochen. Soc. Trans, 21, 930-935.

Golsteyn, E. J., Graham, J. S., Goren, H. J., \& Lefebvre, Y. A. (1989) Prostate 14, 91-10t.

Golsteyn, E. J., Goren, H. J., Lehoux, J. G., \& Lefebvre, Y. A. (1990) Biochem. Biophys. Res. Commun. 171, 336-341.

Gracy, R. W. (19.77) Methods Enzymol. 47, 19\$-204.

Hunter, T., \& Karin, M1. (1992) Cell 70, 375-387.

Hutchison, K. A., Datman, F. C., Hoeck, W., Groner, B., \& Pratt, W. B. (1993) J. Steroid Biochem. Mol. Biol. 46, 681686.

Jensen, E. V. (1991) Curr. Top. Pathol, 83, 365-431.

Jenster, G., van der Korput, H. A. G. M., van Vroonhoven, C., van der Kwast, Th, H., Trapman, J., \& Brinkmann, A. O. (1991) Mol. Endocrinol. 5, 1396-1404.

Jurutka, P. W., Terpening, C. M., \& Haussler, M. R. (I993) Biochentistn 32, 8184-8192.

Kemppainen, J. A., Lane, M. V., Sar, M., \& Wilson, E, M. (1992) J. Biol. Chem. 267, 968-974.

Kennelly, P. J., \& Krebs, E. G. (1991) J. Biol. Chem. 266, $15555-15558$.

Kuiper, G., \& Brinkmann, A. O. (1994) Mol. Cell. Endocrinol. $100,103-107$.

Kuiper, G. G. J. M., de Ruiter, P, E., Grootegned, J. A., \& Brinkmann, A. O. (1991) Mol. Cell. Endocrinol. 80, 65-73.

Kuiper, G. G. J. M., de Ruiter, P. B., Trapman, J., Boersma, W. J. A., Grootegoed, J. A., \& Brinkmann, A. O. (1993) Biochent. J. 291, 95-101.

L.ahooti, H., White, R., Danielian, F. S., \& Parker, M. G. (1994) Mol. Endocrinol. 8, 182-188.

Le Goff, P., Montano, M. M., Schodin, D. J., \& Kattenellenbogen, B. S. (1994) J. Biol, Chen, 269, 4458-4466.

Meisentelder, J., Suh, P. G., Rhee, S. G., \& Hunter, T. (1989) Cell $57,1109-1122$.

Moudgil, V. K. (1990) Binchim. Biophys. Acta 1055, 243-258.

Nakao, M., Mizutani, T., Bhakta, A. Ribarac-Stepic, N., \& Moudgil, V. K. (1992) Arch. Biochem. Bisphys. 298, 340348 .

Orti, E., Bodwell, J. E., \& Munck, A. (1992) Endocr. Rev. 13, $105-128$.

Poletti, A., \& Weigel, N. L. (1993) Mol. Entocrinnl. 7, 241246.

Poletti, A., Conneely, O. M., McDontiell, D. P., Schrader, W. T., O'Malley, B. W., \& Weigel, N. L. (1993) Biochemistry $32,9563-9569$

Rubin, R., \& Watren, R. (1977) Anal. Biochem. 83, 773-778.

Scheidimann, K. H., Echle, B., \& Walter, G. (1982) J. Virol. $44,116-133$

Sefton, B. M. (1991) Methods Enzymol. 20I, 245-251.

Sefton, B. M., Patschinsky, T., Berdot, C., Hunter, T., \& Elliott, T. (1982) J. Virol. 4I, 813-820.

Sheridan, P. L. Krett, N. L., Gordon, J. A. \& Horwitz, K. B. (1988) Mol. Endocrinol. 2, 1329-1342. 
Binchenistry

Sheridan, P. L., Evans, R. M., \& Horwitz, K. B. (1989) J. Biol. Chem. 264, 6520-6528.

Sullivan, W. P., Madden, B. J., McCotmick, D. J., \& Tof, D. O. (1988) J. Biol. Chen. 263, 14717-14723.

Syms, A. J., Notris, J. S., Panko, W. B., \& Smith, R. G. (1985) J. Diol. Chem. 260, 455-461.

Takimoto, G. S., \& thorwit7, K. B. (1993) Trends Endocrinol. Metab, 4, 1-7.

Van der Geer, P., Luo, K., Sefton, B. M., \& Hunter, T. (1993) in Protein Phosphorylation, A practical Approach (tlardie, D. G., Ed.) pp 31-59, Oxford University Press, Oxford.

Van Lasr, J. H., Voorhorst-Ogink, M., Zegers, N. D., Boersma, W. J. A., Claassen, E., Van der Korput, J. A. G. M., Ruizeveld
Phospherylation of the Human Androgen Receptor

de Winter, J. A., Van der Kwast, Th. H., Mulder, E., Trapman, J., \& Brinkmann, A. O. (1989) Mol. Cell. Endoctinol. 67, 29-38.

Van Laar, J. H., Bolt-de Yries, J., Zegers, N. D., Trapman, J., \& Brinkmann, A. O. (1990) Biochem. Biophys. Res. Commun. $166,193-200$

Van Laar, J. H., Berrevoets, C. A., Trapman, J., Zegers, N. D., \& Brinkmann, A. O. (1991) J. Biol, Chem, 266, 3734-3738. Washbum, T., Hocutt, A., Brautigan, D. L., \& Korach, K. S, (1991) Mol. Endocrinol. 5, 235-242.

Weber, M. J. (1972) Nature (London), New Biol. 235, 58. 


\section{CHAPTER 6}

\section{IN VITRO TRANSLATION OF ANDROGEN RECEPTOR cRNA RESULTS IN AN ACTIVATED ANDROGEN RECEPTOR PROTEIN}

George G.J.M. Kuiper, Petra E. de Ruiter, Jan Trapman, Guido Jenster and Albert O. Brinkmann

Biochem. J. (1993) 296, 161-167. 


\title{
In vitro translation of androgen receptor cRNA results in an activated androgen receptor protein
}

\author{
George G. J. M. KUIPER; $\ddagger$ Pelra E. oE RUITER; J Jan TRAPMAN, $†$ Guldo JENSIER* and Albert 0. BRINKMANN"

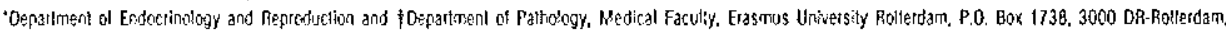 \\ Zhe Nethailands
}

Transiation of androgen receptor (AR) cRNA in a reticulocyte lysate and subsequent analysis of the translation products by SDS/PAGE showed a protein with an apparent molecular mass of $108 \mathrm{kDa}$. Scitchard-plot analysis revealed a single hinding component with high alfinity for R188I $\left(K_{\mathrm{d}}=0.3 \mathrm{nN}\right)$. All $\mathrm{AR}$ molccules synthesized specifically bound sleroid. No evidence for AR phosphorylation dusing in ritron synthesis was found. When $A R$ was habelled with [ $\left.{ }^{3} \mathrm{H}\right] \mathrm{R} 1881$ and analysed on sucrosedensity gradients, a complex of approx. $6 \mathrm{~S}$ was observed. The complex was shified to a higlier sedimentation coeflicient after incubation witl a nonoclonal $\Lambda \mathrm{R}$ antibody directed against an epitope in the DNA hinding domain. In the presence as well as the absence of hormone, AR molecules were able to hind to DNA-cellulose without an activation step. Gel retardation assays revealed that the $A R$ formis complexes with a DNA element containing gfucocorticoid-responsive element/androgen-resnonsive element sequences. Recentor-DNA juteractions were stabilized by different polyclonal antibodies directed against either the $\mathrm{N}$ - or C.terminal part of the $A R$ and were abolished by an antibody directed against the DNA-binding domain of the receptor. In conclusion, translation of AR cRNA in ritro yields an activated $A R$ protein which binds steroid with high aflinity. It is proposed that AR antibodies enhance AR-DNA binding by stabjlizing $A R$ dimers when bound to DNA.

\section{INTRODUCTION}

The androgen recepter (AR) can he isolated in the cytosol of target cell extracts as a large non-activated (i.e. non-DNA. binding) $8 \mathrm{~S}$ complex. Recently, it was shown that this complex contains the $90 \mathrm{xDa}$ hent-sheck protein (hsp 90 ), the $70 \mathrm{kDa}$ heat-shock protein (hsp70) and a 56-59 kDi nrotein [I]. This large multiprolein non-activaled conplex dissociates on bormone binding, thereby revealing the DNA-binding donaain of the receptor [2]. The AR then binds to specific enlancer sequences referred to as homone-responsive elements present in the $5^{\prime}$ flanking region of target genes and is supposed to regulate transcrijtion via protein-DNA interactions ans hy interactions with other transcription factors [3]

the primary structure of the $A \mathrm{R}$ has becu elucifaled, and the domains respensible for ligand binding. DNA hinding, nuelcar localization and transcriptional modulation thave been identified [4,5]. $A R$ belongs to a superfamily of nuclear proteins including the receptors for the other classes of steroid homones, thytoid hormone, vitamin $\mathrm{D}$ and relinoids [6-8]

It is iniportant to understand the intracellular dynanics of steroid receptor proteins and the factors that control their steroid-hinding capacity and DNA-binsling activity. Expression of $A R$ in a suilable host system coutd facilitate our ability to study the physical propertics of the AR protein and the molecular hasis of andirogen action. A variety of systems has heen used for the (over)expression of steroid receptors. The full-fength progcsterone and glucocorticoid receptors lave been expressed in ycast, using fitch horomices ceremisiac as a host system $[9,10]$. Segments of the glucocorticuid. progesterone and androgen receptor cDNAs were expressed in Escherichio coll and were found to exhithit similar biofogical activitics when compared with the native teceptors [11-14]. Attempts to produce full-Jength AR protein by expressing human AR in $E$. coll, yeast or insect cells have heen problematical, resulting, in general, in the synthesis of insoluble proteins [13-16]

Rabbit reticulocyte lysates contain quite targe amounts of several hsps such as hsp 90 and $h s p 70$ and are useful for the study of steroid-receptor complex formation with hsps as well as for the study of requirements for sternid binding and interaction with DNA [17-19].

In the present paper, the in litrn synthesis of the full-length human AR is described as well as the analysis of the stcroidbinding properties, hydrodynamic characteristics and speciffe finding to att androgen-responsive element (ARE).

\section{MAIERIALS AND METHODS}

\section{Materlats}

["S]Mctlionine (specific radioactivity >1000 Ci/nimol) and [y. ${ }^{3}$ P\}ATP were obtained from Amersham (Little Claalfont,

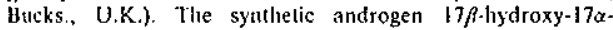
['H]nethyl-4,9,]]-oestratrien-3-one ([3I]R I88I : specific radioactivity annrox. $87 \mathrm{Cj} / \mathrm{nm}$ ol and unlabelled $\mathrm{R}\{881$ were purclased from NEN-Duspent de Nemours ('s-Hertogenbosch, The Netherlands).

Recombinant RNasin and rabbit reticulocyle lysate were obtained from Promega Biotech (Mladison, W1, U.S.A.). RNA transciption kit contaiting $\mathrm{T} 7$ and $\mathrm{T} 3$ RNA polymerase (EC 2.7.7.6) and nelluescript cionitig vector were obtained from Stratagene (La Jollio, CA, U.S.A.).

The antisera spo60 (epitope amino acid residues 20I-222). spoto (cnitope anino acid residues 899-917), sp197 (epitope anino acid residues $I-20$ ) and spo63 (epitope amino acid residues

Abbreviations used: AR, androgen receptor; hsp, heal-shock prolein; GRE. glucocorticold-responsive e'ement: ARE, androgen-responsive e'ement ERE, oestrogen-tesponsive e!errent; RIg81, 17R-hydroxy-17a-melinyl-4,9.11-oesitalien-3-oxte; DIT, dilholhreitol.

t To whom correspondence should bo addressed. 
593-612) were prepared by previously mublisiced procedures $[2,20,21]$. The antisera spl97, sporo and sp063 contain high-titre $A R$ antibodies, as slown by immunoprecipitation and Western blotting $[20-22]$. The antiserum spofo recognizes the 110 II $2 \mathrm{kDa} A \mathrm{R}$ ก

Mouse nonocional antihody $F$ 39.4.I (designated F.39) was prepared against the $\mathrm{N}$-tesminal domain of the androgen receptor [20]. Mouse monoclonal antibody F \$2.24.4 (designated F52) was prepared against the C-terminal patt of the DNA-hinding domain of the androgen receptor [2].

Calf-thymus DNA-cellulose (4 $\mathrm{mg}$ of DNA/g of cellulose) was obtained from Sigma Chemical Co. (St. Louis, MO, U.S.A.). All other chemicals and reagents were purchased from Merck (Darmstadt, Germany).

\section{In vitro transcription and Iranslation}

The coding sequences of human $A R$ CDNA were excised from the expression vector pSVARn [23] at the $\$ \pi / 1$ (EC 3.1,23.37) sites and inserted into the dual promotor $(\mathrm{I} 7 / \mathrm{T} 3)$ vector pBluescript It-KS (Stratagene) and was designated mARO. For transcrintion the vector $(1 / \mathrm{g})$ was linearized with $X / h o l$ (EC 3.1.23.42) (sense CRN $\Lambda$ ) or BamHI (EC 3. 1.23,6) (antisense cRNA) and transcribed in vifro with either T7 RNA polymerase (sense cRNA) or T3 RNA polynerase according to manufacturers' instructions.

Translation reactions $(\$ 0 / 1)$ in rabbit reticulocyte lysates were carried out as recommended by the supplier. Fach reaction nixture included $35 \mathrm{fl}$ of rabbit reticulocyte Iysate, 40 units of RNasin, $10 / \mathrm{A} \mathrm{ZnCl}_{2}, i /$ of I mM amino acid mixture without methionite, $45 / \mathrm{Ci}$ of " $^{\mathrm{S}} \mathrm{S}$ methionine and $1-2 / \mathrm{g}$ of human $\mathrm{AR}$ RNA transcrint. Tlee samples were incubated for 1 li at $30^{\circ} \mathrm{C}$ and thereafter stored at $-20^{\circ} \mathrm{C}$ or used directly. In order to measure the amount of ["Sjinethionine incorporated, samples were subjected to SDS/PAGE ( $7 \%$ geis), sample lanes sere cut in $2 \mathrm{~mm}$ slices and counted in likpuid-scintillation cocktail for ${ }^{3 s} \mathrm{~S}$ radioactivity.

\section{Elactrophoresis, electroblotting and autoradlography}

These were cartied out according to previsusly described procedures [24].

\section{Metabolls labelling of lymph nods carcinoma of the prostale (LNEaP) cells with ["S S]methlonine}

For labelling studies, $6 \times 10^{2}$ LNCaP cells $\{24\}$ were incubated for $60 \mathrm{~min}$ at $37^{\circ} \mathrm{C}$ sith $20 \mu \mathrm{Ci} / \mathrm{ml}$ [ $^{25} \mathrm{~S}$ nnethionine (total $100 \mu \mathrm{Ci}$ ) in methionine-free RPMI 1640 medium. Cell lysis and $A R$ immunopuriffeation were by published procedures [24]

\section{Sterold blading}

Translation reaction mixtures prepased with non-radioactive mathionine were diluted fous fimes with bufter $\wedge[40 \mathrm{mM}$ Tris/HCl, pH 7.4, $1 \mathrm{mM}$ EDTA, $10 \%$ (w/v) glycerol, $10 \mathrm{mM}$ dithiothreitol (DTT), $10 \mathrm{mM} \mathrm{Na} \mathrm{MoO}_{1}, 50 \mathrm{mM} \mathrm{NaF}$ ) and incubated for $3 \mathrm{~h}$ at $4{ }^{\circ} \mathrm{C}$ with $0.1-10 \mathrm{nM}$ ['H]R 1881 in the presence or absence of a 100-fold excess of unlabelled R1881 Thereafter, boutul and anbound steroid were separated with dextran-coated cliarceal.

\section{Sucrose-densily-gradient centrifugalton}

Sucrose density gradients $[10-30 \%(w / v)$ sucrosej were prepared in butrer $A$ with or without $0.4 \mathrm{M}$ NaCl. Reticulocyte lysate containing translation products $(50 \mu$ ) was mixed with $50 \mu 1$ of buffer $A$ ankl incubated with $10 \mathrm{nM}\left[{ }^{3} \mathrm{H}\right] \mathrm{R}[881$ in the presence or absence of a 100 . Fold excess of tinlabelled R 188 I for $2 \mathrm{~h}$ at $4^{\circ} \mathrm{C}$ When appropriate, ascitic huid $(\mathrm{f} / \mathrm{h})$ with monoclonal antibody F39 or F52 or a nor-specific antibody was added. Samples of $40 \mu$ were loaded on to the gradients. The gradients were sun for $20 \mathrm{~h}$ at $50000 \mathrm{rev} / \mathrm{min}$ in a SW-60 rotor (Beckman) at $4^{\circ} \mathrm{C}$ in a Beckman L70 centrifuge. "C.1abelled BSA (4.6 S) and $\left[{ }^{14} \mathrm{C}\right]$ aldolase $(7.9 \mathrm{~S})$ were used as internal markers. Fractions of the gradicnts were collected from the bottom and assayed for radionctivity.

When [ ${ }^{3}$ S J methionine was used to label AR protein during in vitro synthesis, samples of the fractions were incubaled for $\mathrm{I} \mathrm{h}$ at $37^{\circ} \mathrm{C}$ with $\mathrm{I}$ ml of $1 \mathrm{M} \mathrm{NaOH} / 2 \%$ (v/v) $\mathrm{H}_{1} \mathrm{O}$. Proteins were then precipitated hy the addition of $3 \mathrm{ml}$ of $16 \%(\mathrm{w} / \mathrm{v})$ trichloroacetic acid $/ 2 \%(w / v)$ casamino acids, at $4^{\circ} \mathrm{C}$. After centrifugation ( $15 \mathrm{~min}$ at $3000 \mathrm{~g}$ ), pellets were washed witit $0.5 \mathrm{ml}$ of $5 \%$ tricliloroacetic acid and thereafter solubilized in I $\mathrm{M} \mathrm{NaOH}$. After neutralization with cone. $\mathrm{HCl}$, samples were analysed for ${ }^{\text {is }} \mathrm{S}$ radioactivity by liquid-scintillation counting.

\section{DNA-cellutose chromalography}

Reticulocyte iysate containing ["s] $\$$ methionine-lahelled transIation products or non-radioactive receptor was diluted five times with TEDG butTet $(40 \mathrm{mM}$ Tris/HCl, nH 7.4, I mM EDT $\Lambda, 10 \mathrm{mM}$ DTT and $10 \%(w / v)$ glycerol $)$ and incuhated for

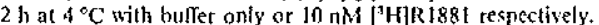

A DNA-cellutose suspension $(12.5 \%, w / v)$ of $750 \mu$ was added to $300 \mathrm{pl}$ of diluted lysate and incubated for $60-120$ min at $4{ }^{\circ} \mathrm{C}$ with consiant mixing. The mixture was poured into a smail column and washed with TEDG buffer until no free radiolahelled steroid could be monitored. Bound "H-labclled steroid was eluted with TEDG buffer containing I $\mathrm{M} \mathrm{NaCl}$; fractions of 100 / were collected. Alternatively, bound ' $\mathrm{H}$-labelled steroid was eluted with a gradient ranging from 50 to $300 \mathrm{mM} \mathrm{NaCl}$ in TEDG huffer. Conductivity was measured with a Philips PW9SOS conductivity meter equipned with a PW-9513 measuring cell (constant 1,62). Conduclivity was compared with a standard curve of known $\mathrm{NaCl}$ concentration in the appropriate huffer. When ["s]melhionine-labelled lysates were uscd, fractions of the cloate were run on an SDS $/ 7 \%$ nolyacrylamide gel and blotted to nitroceilutose. After autoradiography, the blot was sliced and the stices were counted after solubilization in Fittercount cocktail (Packard Company).

\section{Gel rolardation assay}

A glucocorticoid-responsive element (GRE) consensus oligonucleotide sequence $5^{\prime}$-TCGACTGTACAGGATGTTCTAGC 'TACT-3' was obtained from Promega. Double-stranded oligonucleotide was labelled using T4 polynucleotide kinase with $\left[\gamma-{ }^{32}\right.$ P]ATP to a specific radioactivity of $5 \times 10^{9} \mathrm{~d} . \mathrm{p} \cdot \mathrm{m} . / 1 \mathrm{~g}$

The binding reaclion mixture $(15 \mu)$ contained typically $2 \mu \mathrm{I}$ of reticulocyte lysate (1.5-2 fmol of $A R$ protein) with $2 \mu \mathrm{g}$ of poly (di-dC) poly(dl-dC) in bufter [to mM Hepes, $\mathrm{pH} 7.9$, $60 \mathrm{mAI} \mathrm{KCl}, \mathrm{ImM} \mathrm{DTT}, 1 \mathrm{mMI}$ EDTA, $4 \%$ Ficoll and $0.2 \mathrm{ng}$ (12 fmol) of lahelled GRE. After incubation for 30 min on ice, the protein-hound DNA complexes were separated from free probe on a $4 \%$ polyacrylamide gel (45:1) fun in $0.25 \times$ THE $(1 \times \mathrm{TBE}=50 \mathrm{mM}$ Tris base, $50 \mathrm{mM}$ boric acid, $1 \mathrm{mM}$ EDTA, pli 8.6) for $1.52 \mathrm{l}$ at room temperature. Gels were fixed for 
$15 \mathrm{~min}$ in $10 \%$ acetic acid $/ 10 \%$ methanol, dried and autotadiograplied.

In experiments with AR antibadics, $0.1 / 1$ portions of antisera were preincuhated for $I$ in at $4^{\circ} \mathrm{C}$ with reticulocyle lysates before addition of reaction mixture.

Bcsides unlatelled GRE, two other oligonticleotides wese used for competition experiments: one containing an ARE from the prostate-specific antigen promotor (position -170 to -156 ) sequence 5'GATCCAGCTAGCACTTGCTGTTCTGCAAG$y$ according to Riegnan et as. [25] and one containing an oestrogen-responsive elcment (ERE) [26] from the apo-very-fowdensity lipoprotein II promotor region (position -165 to -177 ), sequence 5'-GATCCTCAGGTCAGACTGACCTTCG-3: kindly provided by Dr. G. AB, Departnent of Biochemistry, Universily of Groningen, The Netherlands.

\section{Site-dlected mulagenesis}

The AR mutant in which Cys-602 and Cys-605 were mutated to Ser residues was constructed by site-directed mutagenesis using PCR DNA-amplification techiniques on PSVAR0 [23]. The primer used to introduce the mutation was $5^{\prime}$-CCGAAGGAAGAATTCTCCATCTTCTCGTC- 3 . From the resulting mulant plasmid pSVAR6S, a $700 \mathrm{hp} B s t$ EH - Aspl fragnent was excised and exchanged with pAR0. The mulant transcription vector was designated pAR6s.

\section{MESULIS}

\section{Characterizallon of All syntheslzed in rabblt reliculocyte fysate}

The rabhit reticulocyte lysate was programmed for protein synthesis with in vitro transcribed human $A R$ cRNA in the presence of $[$ "S]methionine. Analysis of the translation products by SDS/PAGE showed a predominant band with an apparent molecular mass of $108 \mathrm{kDa}$ (Figure 1). For comparison, the result of a labelling experiment with $L N C a P$ ceils is shown. The AR from LNCaP cells migrates as a closely spaced doublet of $110-112 \mathrm{kDa}$ on SDS/PAGE as described previously [24]. This heterogeneity reflects diferential AR phosphorylation $[22,24]$. From the results shown in Figire 1 , it is clear that the $A R$ in reticulocytè lysate is synltesized as a single $108 \mathrm{kDa}$ protein, intlicating that it is not phosploorylated during in vitrn synthesis $\mathrm{j}$ in the same way as during synthesis in LNCal' cells. $\Lambda$ lso, after incubation of reticulocyte lysates witl [ $\gamma^{-3}$ "P] $\mathrm{ATP}$ during $\Lambda \mathrm{R}$ synthesis, it was not possible to detect phosphorylated $A R$ after inmunopurification, whereas several other unknown phosphorylated proteins could be detected in the lysate (resula not shown).

In order to analyse the steroid-binding properties of $A R$ synthesized in tisro, the reticulocyte lysate was incubated at $4{ }^{\circ} \mathrm{C}$ for $3 \mathrm{~h}$ with increasing concentrations $(0.1-10 \mathrm{nM})$ of ['H $\mathrm{H}$ R 1881 in the presence ot absence of a 100-fold molar excess of unlabetled R/881. Lincar transformation of saturation data revealed a uniform non-interacting propulation of hinding sites for RI881 wilh a maximum hinding capacily of $480 \mathrm{fmol} / \mathrm{ml}$ and a dissociation constant of $0.3 \mathrm{nM}$ (Figure 2).

In pasallel experiments, the amount of synthesized $A R$ protein was determined hy incorporation or [ ${ }^{13}$ S'ntethionine. The amount was estimated from methionine pool size ( $5 / \mathrm{M}$ according to the manufacturer), the amount of ["S|methionine incornorated and the number of methionine residues in the receptor molecule. It is calculated that each of the intact (108 kDa) AR proteins binds $1.0 \pm 0.1(n=2)$ molccules of R1881 at a saturating ligand concentration.
When the $A R$ was lahelled with ['H]R 188 and analysed on sucrose density gradients, a single neak of specifically bound radionctivily (rigure 3a) was observed. The sedimentation coeflicient of this complex was approx. $6 \mathrm{~S}$. In the presence of high salt $(0.4 \mathrm{M} \mathrm{NaCl})$, the sedimentation coeflicient of $A R$ shifted to $4 \mathrm{~S}$. When the $A \mathrm{R}$ was synthesized in the presence of $\left[{ }^{3 \text { "Slmethioninc, }}\right.$ the sedimentation coeflicient was also approx. $6 \mathrm{~S}$, and slifted to $4 \mathrm{~S}$ in the presence of high salt (results not shown).

The monocional antibody $F 39$ is directed against an epitope in the N-terminus of AR (aminn acio residues $301-320$ ) and was able to shift the 6 S AR complex to a sedimentation coefficient of about $10 \mathrm{~S}$. Also, the monoclonal antibody F52 which is directed against an epitope in the DNA-binding domain (amisto acid residues $593-612$ ) was able to stift the $6 \mathrm{~S}$ complex to a higher sedimentation coefficient $(8 S$ ) (Figure $3 b$ ). This indicates that the DNA-binding elomain is exposed in the $6 \mathrm{~S} \mathrm{AR}$ complex. $A$

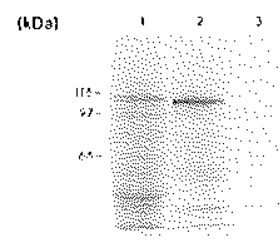

\section{Flguro 1 Synthesls of AR in fabbit rellculocyle lysate and in LNCaP cells}

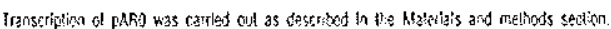

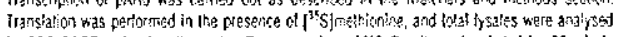

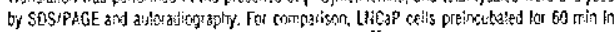

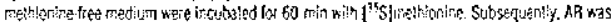

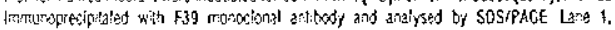

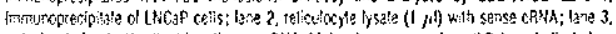

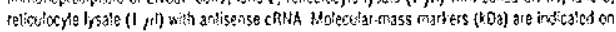
the lest

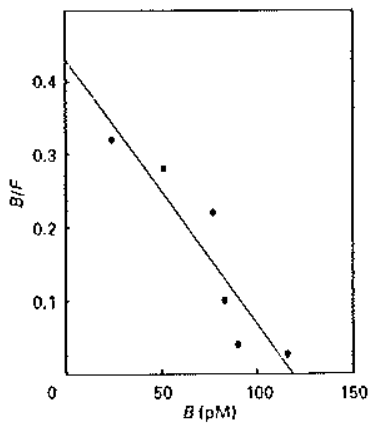

Flgute 2 Scalchard plot of ['H]R 1881 binding to AR syntheslzed in vitro

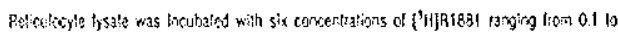

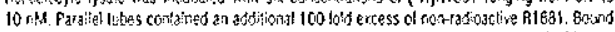

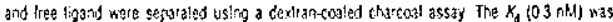

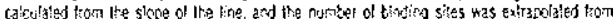

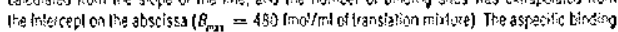
was less than 58 of wit bi:sing 


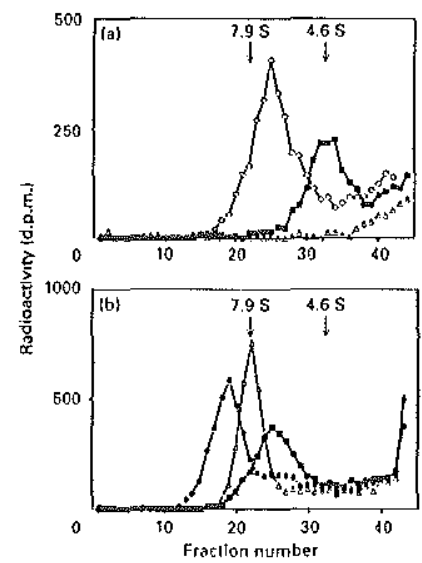

Flgure 3 Sucrose-density-gradient profles of kaman Af syntheslaed in vilro

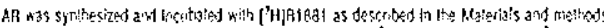

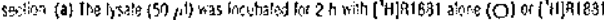

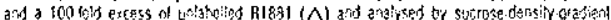

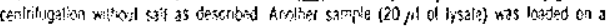

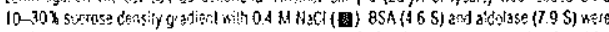

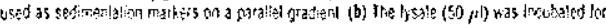

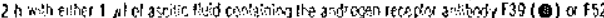

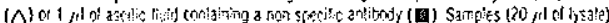

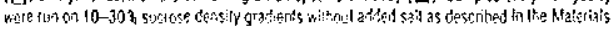
and methinds section

control sample of mouse ascitcs containiug menoclonit antihodies against the Fos oncoprotein was not able to change the scdimentation coelticient of the $6 S A R$ complex (Figure $3 h$ ).

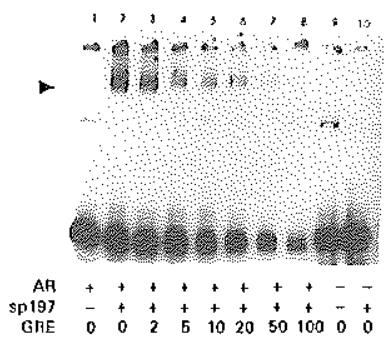

Figure 5 Binding of AH syatheslied In vifro to a GRE

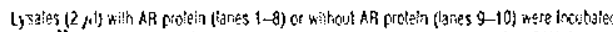

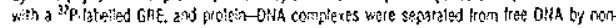

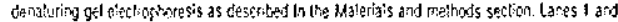

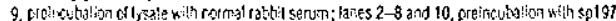

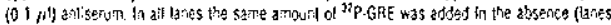

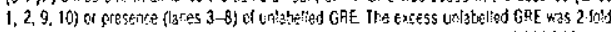

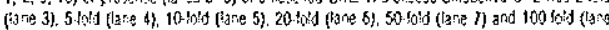
8) The AR- GAE complen is findicaled ty on arrow.

\section{DNA-blnding properties of human Ah synthesized in viltro}

1futeraction of receptors witl? DNA-cellulose is generally used as a measure of activation to the DNA-binding state of steroid seceptors. Human AR synthesized in ritro s'as tested for binding ability to DNA-cellulose after bcing habelled with $\left[^{3} \mathrm{H}\right] \mathrm{R} / 881$ for $2 \mathrm{l}$ at $4^{\circ} \mathrm{C}$. Figure $4($ a) estolltished that $A R$ synthesized $m$ sitrn is retained on a DNA-cellutose coltumn. The AR was alsn eluted from the DNA cellulose with a linear salt gradient and was obtainesl in the fractions containing $120 \mathrm{mM} \mathrm{NaCl}(t=2)$ (IFigure 4b). Experiments with "S-tabelled $A R$ incubated with DNA-cellulose in the atsence of R 1881 gave simiłar results. So it appears that the presence of hormone is not essential for $A R$ to be abie to bind to DNA-celfulose.

In further experiments, we have tested the ability of the $A R$

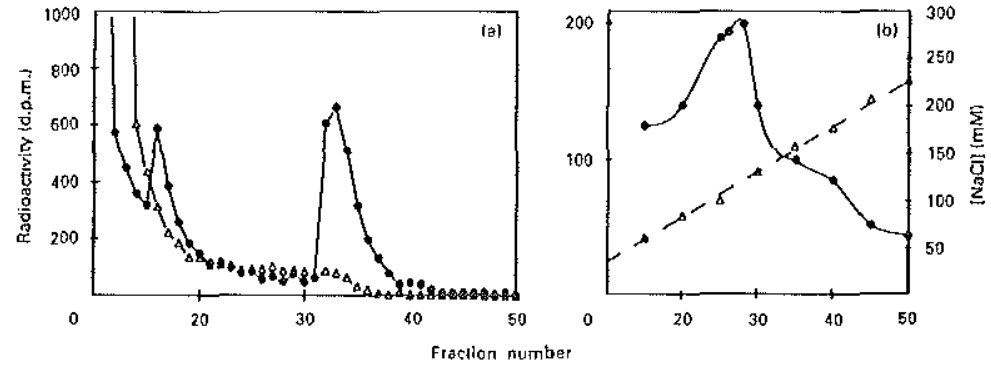

Figure 4 Etullon from ONA-cellufose of AR synthesized in vilro

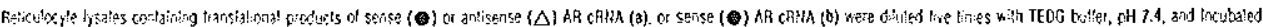

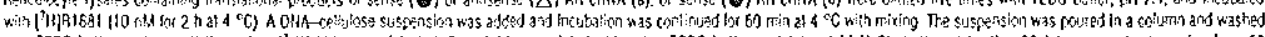

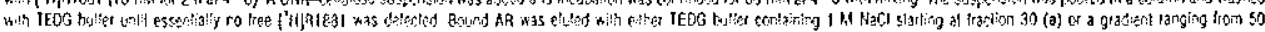

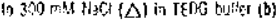


A

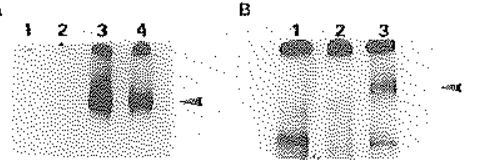

Flqure 6 Binoting ol AR synthesized in vilio to "p.labelled QnE: Inliuence of prelncubation with llgand or salt

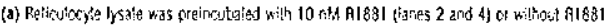

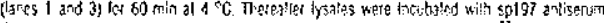

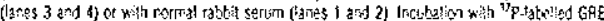

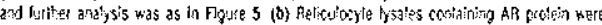

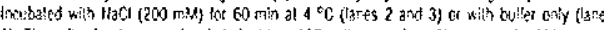

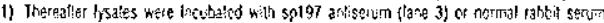

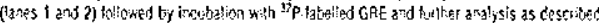
The AR-GRE complex is tonficaled by an arrext.

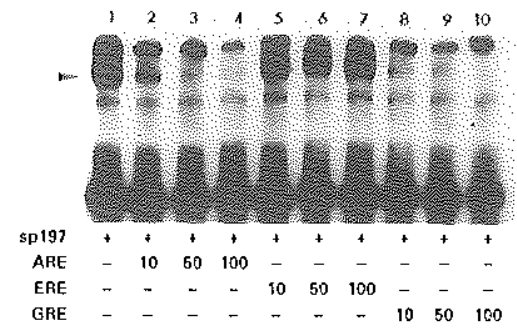

Flouse 7 DNA-blanding spectictily of AR synithesized in vifro

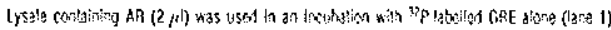

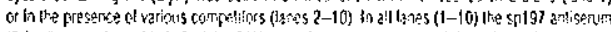

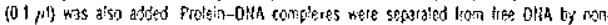

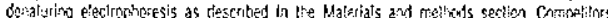

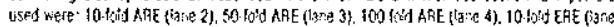

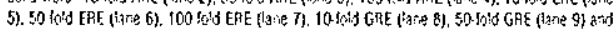

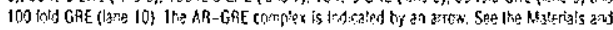

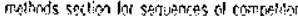

synlliesized in vitro to interact with specific DNA sequences, For these experiments, a consensus GRE was used, which has previously been shown to confer androgen-responsiveness to a repozter gene [4]. Reliculocyle lysiltes containing AR putein, but not lysatcs programmed with antisense $A R C R N \Lambda$, were able to interact with a 27 -mer oligonucleotide containing the abovementioned GRE, as shown by gel nobility-shift assays. However, the conplexes observed were very faint. likubation with an antiserwm ogainst $A R$, recognizing the first 20 anino acioss (sp 197), resulted in an apparent stibilization of the GRE-AR complexes (Figure 5). Addition of normal rabbit serum to reliculocyte lysates or antiscrum against $A R$ to a lysate not containing AR failed to show simikat complexes. Compctition with unlahelled GRE of the GRE-AR complex in the presence of antiserum sp197 was almost complete at a 20 -50-fold excess of untabelled GRE, confirming the specificity of the obsersed conplexes (Figure 5).

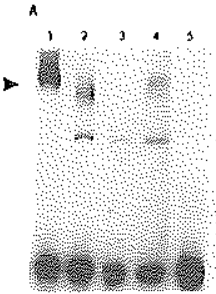

Antibody 197050063056 .

ARO
6

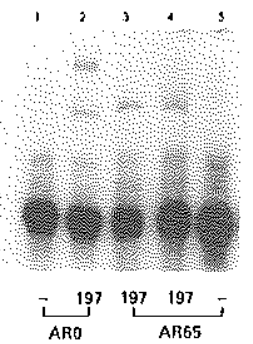

Flgure 8 (a) BInding of AR synitiestzed in vitro to "P.labelled GRE in the presence of valous AR antisera and (b) GaE blading of wild lypa and a mulant AR

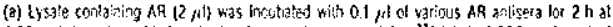

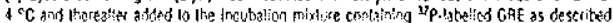

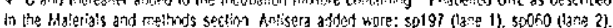

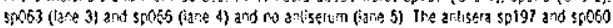

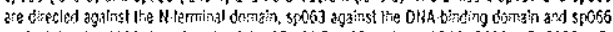

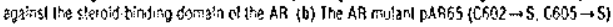

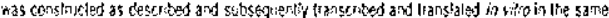

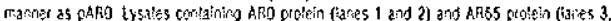

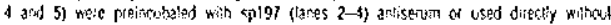

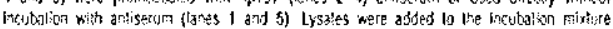

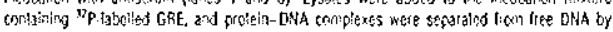

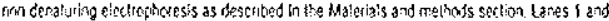

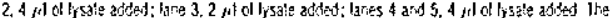

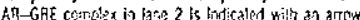

After preincubation of the reticulocyte fysate with R1881, specific GRE-AR complexes could also only be observed in the presence of $A R$ antiserum spl97 (Figure 6a). The reliculocyte lysates were pretreated with salt in order to convert the $6 S A R$ into the $4 \mathrm{~S} \wedge \mathrm{R}$ species (sce Figure 4), In this case also, GRE-AR complexes were ebserved only in the presence of the 5 p 197 antiserum (Figure 6 b). The GRE- $\wedge$ R complex can conpele with an ARE from the srostate-specific anligen promotor [25], which has been sliown to confer androgen-responsiveness on a reporter gene (Figure 7). In contrast, flie GRE-AR complex could not compete with an ERE from the ano-very-low-density lipoprotein II promotor region [26], confirming the specilicity of the GREAR interaction.

In addition to the sp197 antiserum, several other AR antisera were able to stabilize the GIRE-AR complex, although to at lesser extent (Figure 8a). Interestingly, after preincubation of the reticulocyte lysate witl an antiserum directed against the sccond zine finger of the DNA-binding domain (SPn63 antiserum), no labelled GRE-AR complexes were observed. This confirned that the DNA-binding domain of AR interacts with the labclled GRE

The DNA-binding domain of steroid receptors contains two zine ions which are tecrahedrally co-ordinated by cysteine residues. Mutagenesis experiments have shown that these cysteine residues are cssential for DNA-binding capacity [27]

The cy'sleituc residues at positions 602 and 605 in the DNAbinding domaist of the AR protein were mutated to serinc residues, an anino acid that is structurally closely related to cysteine but which has not been found to co-ordinate zinc ions in any zinc-containing protein [28]. The mutant obtained (designated pAR65) wax transcribed and translated in titro. Similar 
amounts of $A R A$ and $A R 65$ protein were tested in a gel mobility slift assay with labelled GRE (Figure 8h). No AR6S-GRE complexes were ohscred, showing that $A R$ dees indeed inleract vin the DNA-hinding domain with the GRE, an interaction that is apparently stahilized by the presence of anti- $\mathrm{AR}$ antisenum.

\section{DISCUSSION}

The rabbit reticulocyte lysatc appears to be a convenicnt system for the synthesis of $A R$ protein. The AR protein mroduced lias a bigh hindizg allntily for androgenic stcroids $\left(K_{t}^{*}, 0.3 \mathrm{nM}\right)$ which is in agreenent with previously reported dissociation constanls for human androgen receptors îl various cellular systems [29.31] The difference in apparent molecular mass between the AR synthesized in cilro (108 kDa) and the AR from LNCaP cells (1 $10 \mathrm{kDa}$ ) is due to a diliterence in the length of the polyglutamine stretch in the N-terminus. Varinus lengths of the Juman AR polypeptide, deduced from cDNAs isolated in different faboratories, have been reported [13]. The vector pSVAR0 [23], which has been used for the construction of the PARO vector, contains 20 glutamine codous, whereas the $A R$ cDNA isolated from the LNCaP cells contains 27 glutamine codons (J. Trapnian and $H$. Sleddens, unplublished werk). The doublet appeatance of the $A R$ from LNCaP cells (LIO-112 kDa) is caused by differential phosphoryfation [24]. Alkaline phosphatase treatment of cytosols from LNCaP cells caused a gradual elinination of the $112 \mathrm{kDa}$ isoform, with a concomitant increase in the $110 \mathrm{kDa}$ isoform [24].

All AR molccules synthesized were ahle to bind steroid, and there was no evidence available for $A R$ phospitorylation during in titro synthesis. I luis suggests that $\mathrm{AR}$ phesphorylation is not estential for bormene hinding, at least in t'fro. This conclusion is corroborated hy the finding that, in LNCaP cells, AR is not plosphorylated in the DNA- and steroid-binding domains [22] lis contrast, the in tifro synthesized oestrogen receptor binds ocstradiol with high affinity, but low efficiency. Only a kinase puriffed from calf uterus was able to convert most of the nonhormone-binding nestrogen receptor into a steroid-binding state [18,32].

Other than $\mathrm{AR}$, in mitro synthesized 1,25-dihydroxyvitamin $\mathrm{D}$, receptor and glucocorticoid receptor were also athle to bind steroid with high affinity willout previous phosphorylation hy an exogenous kinase $[17,3,3\}$. For the $i n$ sitro synthesized human progesterne receptor also, it has been shown that phosphorylation is not essentiat for steroid hinding [34].

Steroid trommone receptors can be isolated fiom the cylosol of target cell extracts as large non-activited $8 \mathrm{~S}$ complexes, containing hsj90, bisp 70 and $p 56[1-2]$.

In a recent study [2], the hormone-induced transformation of $A R$ in human prostale carcineina cells (LNCaP cell line) was described. On incubation of the cells with RI88I for 30 min at $37^{\circ} \mathrm{C}$, the sedimentation value of the cytosolic $A R$ decreased from $8 \mathrm{~S}$ (non-DNA-binding form of $A R$ ) to an intermediate form of $6 \mathrm{~S}$. The monoclonal antibody FS2 (directed against the DNA binding donain) specifically recognized the $6 \mathrm{~S}$ form of the $\Lambda \mathrm{R}$ from LNCaP cells, but not the non-DNA-binding $8 \mathrm{~S}$ $A R$ complex [2]. It appears that the $6 S A R$ detected in reticulocyte lysate is similar to the $6 S A R$ detected in the cytosol of LNCaP cells after incubation with R 1881 at $37^{\circ} \mathrm{C}$. The AR synthesized in reticuiocyte lysate $(6, S)$ can therefore be regarded as an activated protein. In previous studies, we have shown that the DNA-binding form of $A R$ in calf uterus cytosol also has a sedimetzation cocficient of $6 \mathrm{~S}$ [35]. whereas the non-DNAbinding $A R$ has a sedimentation coeflicient of $8 \mathrm{~S}$. In this respect it is interesting to note that $A R$ from calf uterus cytosol and
LNCaP cell nuclcas cxtracts and $A R$ synthesized in vifro (Figure 4b) are all eluted from DNA-cellulose at an $\mathrm{NaCl}$ concentration of [20-140 mM [35] (G. G. J. M. Kuiner, P. E. de Ikuiter, J. Trapman, G. Jenster and A. O. Brinkmann, unpublished work).

The composition of the $6 \mathrm{~S}$ AR complex in reticulocyte lysate is at present unknown. It could represent a receptor dimer or a complex with other proteins such as hşn70. After immunoprecipitation of AR fron reticulocyte lysate with F39 antibody and subsequent immunoblotting with anti-hsp 90 and anti-hsp70 antibodies, no signal above hackground was detected. We concluded that the amount of $A R$ protein present in reliculocyte lysate is not sulficient to produce a signal with ant: $-h s_{\text {sp }}$ antibodies on Western blots. In similar experiments, the $6 \mathrm{~S} A R$ complex from LNCaP cell cytosol was shown to contain hsp70 and essentially no hsp90 and p56 [2]. The anti-hsp70 anlibedy we used (N27 monoclonal antibody from Dr. W. J. Welch, University of California, San Francisco, CA, U.S.A.) does not recognize the native forms of the protein very well. Conseguently, it was not possible to shift the $6 \mathrm{~S}$ complex on stcrose density gradients with $N 27$ antibody, as we did with anti- $A R$ antibodies.

Under similar conditions to those in the present paper, the glucocorticoid receptor was detected as a $9 \mathrm{~S}$ non-DNA-binding protein [19]. Only after incubation of the $m$ visro synthesized glucocorticoid receptor with the agonist dexamethasone and licat-treatment were receptors able to bind to DNA-celtulose. In the present investigation it is shown that AR is able to bind to DNA-cellulose, even in the absence of homone and heattreatment, indicating that it is present as an actiyated protein.

It is not known at present why the $A R$ in reticulocyte lysate does not form a stahle $8 \mathrm{~S}$ conniex, despite the presence of molybdate. Molyhdate las been slown to stabilize the 8 S AR complex in calf uterus cytosol, alihough its presence is not essential for the detection of this connlex [35]. For the glucocorticoid receptor in reticulocyte Jysates, it has heen shown that 17 spo is necessary but not in itself sufficient for the formation of the non-activated (non-DNA-bilding) teceptor complex [36]. Other components might be needed for the formation of the $8 \mathrm{~S}$ $A R$ complex which are either not present at an in the reticulocyte lysate or not in sufficient amounts.

The human AR syntiesized in vifro displays specific binding to target DNA sequences as shown using the get inobihity-shift assay. The complexes formed are DNA-sequence-specific, as they form in the presence of high concentrations of poly(d)dC) poly (dI-dC) and can compete with low molar ratios of GRE/ARE secitences but not an unrelated ERE sequence. Ifowever, the affinity for these rcsponsive elements is rather low. Only in the presence of specific $A R$ antiscra can stable comptexes be delected. This is the case for the $4 \mathrm{~S} \mathrm{AR}$ protcin as well as for Ithe 6 S AR complex (Figure 6). Such a statilization has also been described in mobility-shift assays with antibodies directed against the progesterone receptor [.37], and more recently atso for complexes formed between a fragnient of $A$ R expressed in $E$. coli and $A R E / G R E$ oligonucleotides [38]. Stetoid hormone recentors can bind as symmetrical dimers to palindromic steroid responsive elements $\{27\}$. The stabilization of the AR-GRE complex in the presence of $A R$ antisera could be explained by antibody-induced $A R$ dimerization witt the result that high-afinity DNA binding is achieved. For the in witrn synthesized nouse oestrogen receptor, it has been shown that there is a direct correlation between sjecific DNA bitlding and dinerization [39].

Another explanation, other than the absence of AR dimerization, for the low-alinity DNA binding might be that ARassociated proteins entancing the interaction of $A R$ protein and DNA are missing from the present system. There is strong 
evidence available suggesting that receptors interact with other factors involved in transcriptional regulation and that such protcin protcin contacts might increase the affinity of receptors for responsive elements $[40-4,3]$. The present system, involving AR synthesized in reticulocyte lysate, could serve as a valuable probe in measuring and isolating stich putative factor(s) from nuciear extracts of target cells.

Thls witrk was supported by the Nelthealands Oiganlzation for Sciegatilic Research (NWO) Whough GB MW (Wedical Sclences), and by a grant from The Netheslands Carcer Sociely.

\section{BEFERENCES}

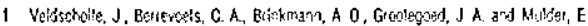
(1992) Bitherristry 31, 2393-2399

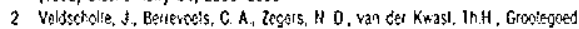
$J$. A and M.jker, $E$ (1932) Biochenis!ry 31, 7422-7430

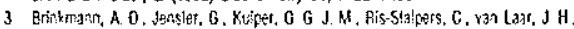

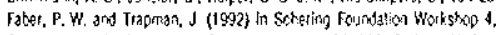

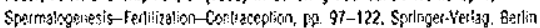

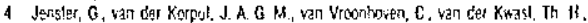
Trapris?. J and Grinkmasin, A 0. (I991) Ked. Endocrinot. 5. 1395-1404

5 Sirenenlat, J A. Sas, M. L are, M. V. Fiench, F. S and Wisco, \&. M. (1991) J. bict Chem 286. 510-518

6 Bealo. M. \{1989) Ce:1 56, 335-344

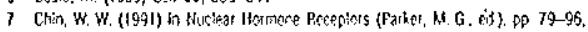
Acarterra'c Fiess, Londora

8 Ham, J a $\leadsto$ Folker, M. G. (1989) Catr. Opin. Cell Bonl. 1, 503-511

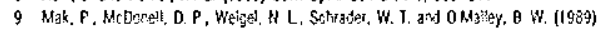
$J$ Eiol, chan 254, 21513-21518

10 Sctera, is and Yamamoia. $K$ R (1989) Sclence 241. $565-957$

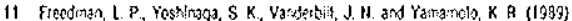
Scrience 245, 29B-301

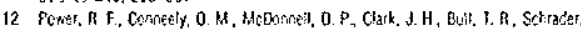

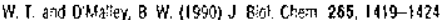

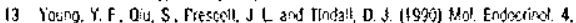
$184\{-1 B, 9$

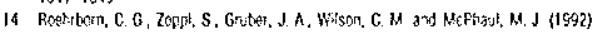
Mol Ceil Eniforinol. 84, 1-i4

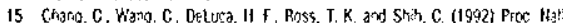
Acad Sol U.S.A $89,5936-5950$

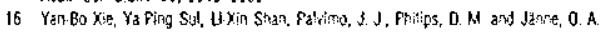
(1992) J Binl Chers 267, 4939-4949

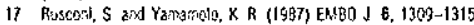

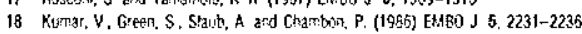

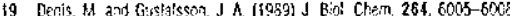

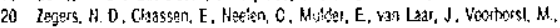

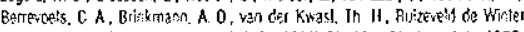

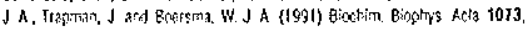
23-32

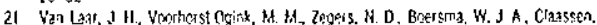

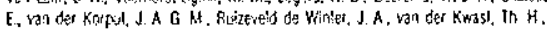

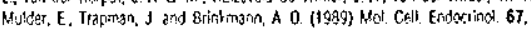
$29-38$

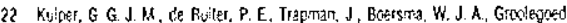
J. A and Brinkramn, A. 0 (1993) Birchem J. 291, 95-101

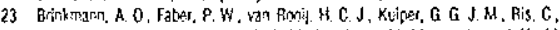

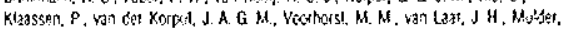
$E$ anf Irapman. J (1989) J Stercid Biactern. 34, 307-3 to

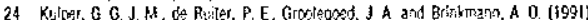
Nol. Cell Endocinol. 80, 65-73

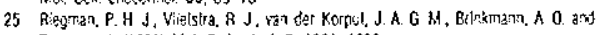
Trapiran, J. (1991) Mol Enifortiol. 5, 1921-1930

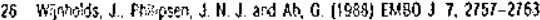

27 Freedrada, L P. (1992) Endacise Rev. 13, 129-146

28 Valtse. B.t and Al, of. D. S (1990) Bixchemis!ry $29,5547-5659$

29 Ris-Stalpers, C. Kuiper, G. G.J.M. Faher, P. W. Sthweiker, K. U, van Aopij.

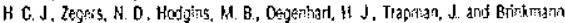
A 0 \{1990) froc Nall ACdd. Sct USA. 87, 7866-7870

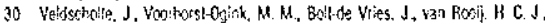

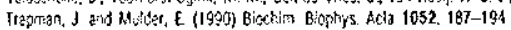

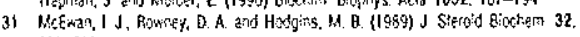
$789=795$

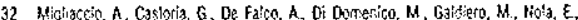

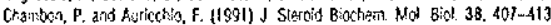

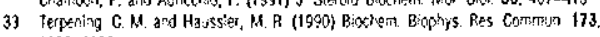
1129-1136

34 Allan, G F, Leng. X. Tsai, S Y. Yeingl, H L, Edwatds, D. P., Isal. M.J. and DHal!ey, a W (1992) J. Biol, CNem, 257, 19513-19520

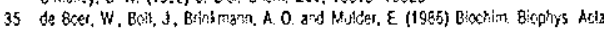
889. 240-250

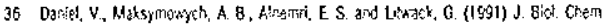
268. 1320-1325

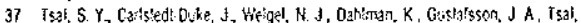
M. J. ard OMa!tey, B. W. (\$988) Ceil 55. 361-359

as Tan, J A, Matschle, X. B. Ho, K. C, Peny. S T, Wisga E M and Fiench, F. S (1922) $\mathrm{J}$ Bind Chern, 257, 4456-1456

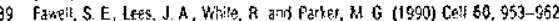

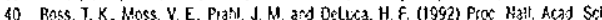
USA BS, 256, 260

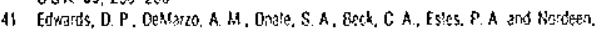
$S \times$ (1991) Steroids 56. 271-278

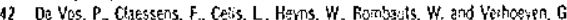
(1983) An N.Y. Arad. Srt 684. 202-204

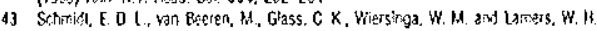
(1993) Bioctim Biopliys Asis 11\}2, 82-88

Recelived 8 March i993/25 June 1993; actenles 21 Jily 1993 


\section{CHAPTER 7}

\section{DISCUSSION}




\subsection{Androgen receptor protein in LNCaP cells}

In many experiments described in this thesis, the LNCaP cell line, derived from a fast growing colony of a Lymph Node Carcinoma of the Prostate, was used as a model system to study androgen receptor phosphorylation. This cell line contains a high amount of androgen receptor molecules, and shows androgenstimulated growth in culture (Horoszewicz et al., 1983; Schuurmans et al., 1988; van Steenbrugge et al., 1991). The growth of LNCaP cells was not only stimulated by androgens, but also by estrogens and progestins (Schuurmans et al., 1988). This was surprising, since the LNCaP cells do not contain estrogen and progesterone receptors (Berns et al., 1986; Schuurmans et al., 1988). Examination of the binding characteristics of the androgen receptor in LNCaP cells, in comparison with the binding characteristics of the wild type androgen receptor in COS cells, in normal human skin fibroblasts, and in PC-3 (prostate tumor) cells, revealed an abnormal high binding affinity for progesterone and estrogen of the LNCaP cell androgen receptor (Veldscholte et al.,1990A). A point mutation in the $\mathrm{LNCaP}$ cell androgen receptor gene was detected, which resulted in the substitution of Thr 868 by Ala (Veldscholte et al.,1990B). After transient expression of this mutated androgen receptor in COS or HeLa cells, it was shown that not only androgens, but also progestagens and estrogens, albeit it at high concentrations, could stimulate the expression of an androgen receptor responsive reporter gene (Veldscholte et al.,1990B; Ris-Stalpers et al.,1993). Nevertheless, the androgen receptor in $\mathrm{LNCaP}$ cells has a normal binding affinity for androgens ( $\mathrm{Kd} 0.4 \mathrm{nM}$ ) (Veldscholte et al., 1990A). After transfection of GRE/ARE containing reporter constructs in LNCaP cells, the endogenous androgen receptor was able to mediate enhancement of transcription, upon incubation of cells with T or DHT (Denison et al.,1989; Warrian et al, 1994). Prostate specific antigen (PSA) mRNA expression could be 
upregulated by androgens, as is the case in prostatic tissue (Riegman et al.,1991; Swinnen et al., 1994). No other properties of the androgen receptor in LNCaP cells, apart from the changed ligand binding specificity, are affected compared to the wild type androgen receptor, as far as is known. The high expression of androgen receptor protein and the androgen responsiveness make LNCaP cells a suitable model to study androgen receptor phosphorylation. Finally, the codon 868 mutation in the androgen receptor gene is not an unique property of LNCaP cells, nor an artefact of cell culture, since the same mutation was found in 6 out of 24 prostatic tissue specimens of patients with metastatic prostate cancer (Gaddipati et al.,1994). In another study, the codon 868 mutation was found in metastatic tissue from 1 out of 8 cases of endocrine therapy resistant prostate cancer (Suzuki et al., 1993). Possibly, the codon 868 mutant androgen receptor provides a selective growth advantage in the genesis of a subset of prostate cancers.

\subsection{Heterogeneity of the androgen receptor}

The androgen receptor isolated from LNCaP cells migrates as a closely spaced doublet of 110-112 kDa apparent molecular mass during SDS-PAGE (Chapter $3)$. The $112 \mathrm{kDa}$ isoform reflects the phosphorylated androgen receptor, and the $110 \mathrm{kDa}$ isoform the non-phosphorylated receptor (Chapters 5 and 6). Also other proteins, like for example the retinoblastoma protein (Buchkovich et al.,1989), pp60 c-src (Gould et al.,1985), and the Dictyostelium cAMP receptor (Hereld et al.,1994), show a decrease in their mobility on SDS-PAGE gels upon phosphorylation. These shifts are probably caused by variable binding of SDS, affecting the net charge of the protein-SDS complex (Blackshear,1984). The observed androgen receptor heterogeneity is not a characteristic of LNCaP cells 
only, since the same androgen receptor doublet was also observed in genital skin fibroblasts, and in CHO cells stably transfected with human androgen receptor cDNA (Ris-Stalpers et al.,1994; unpublished results). The androgen receptor doublet is already present in LNCaP cells which have not been incubated with hormone, indicating that the doublet is caused by a hormone independent phosphorylation step (Chapters 3 and 5; Kuiper et al, 1992). This is confirmed by the fact that in genital skin fibroblasts from individuals with androgen insensitivity, expressing androgen receptors which are unable to bind hormone, the androgen receptor is also a doublet on SDS-PAGE (Ris-Stalpers et al.,1994). The wild type human androgen receptor and six different androgen receptor proteins specifically mutated to obtain different amino acid residues at position 868, were transiently expressed in COS cells. Again, in all cases the androgen receptor migrated as a doublet on SDS-PAGE, irrespective whether or not the mutants were able to bind hormone (Ris-Stalpers et al.,1993). In labeling experiments with $\left[{ }^{32} \mathrm{P}\right]$-orthophosphate of $\mathrm{CHO}$ cells expressing the human androgen receptor protein, only the $112 \mathrm{kDa}$ isoform was labeled, as was shown for the androgen receptor from LNCaP cells (Chapter 5, and unpublished results).

In conclusion, these studies in different cell systems provide evidence for the existence of a hormone independent (basal) phosphorylation step and show that androgen receptor heterogeneity is caused by phosphorylation (Chapters 3 and 5). Furthermore, the fact that androgen receptor heterogeneity is observed in various cell types, even in cells not normally expressing androgen receptor protein, indicates that ubiquitous kinase(s) are involved.

\subsubsection{Heterogeneity of the androgen receptor and ligand binding}

Both isoforms of the androgen receptor are able to bind ligand, since both 
isoforms are able to undergo hormone dependent transformation to the tight nuclear binding form in LNCaP cells (Chapter 3). Also, both isoforms can be labeled specifically with $\left[{ }^{3} \mathrm{H}\right]-\mathrm{R} 1881$ upon photolabeling of androgen receptors in LNCaP cells (van Laar et al.,1990). Since the $110 \mathrm{kDa}$ isoform is not phosphorylated, this indicates that androgen receptor phosphorylation is not essential for the acquisition of ligand binding capacity in target cells. Previous studies showed that in rat prostate cells the androgen receptor protein is rapidly inactivated to a form that is unable to bind ligand upon treatment of cells with dinitrophenol (which results in uncoupling of mitochondrial respiration and ATP synthesis), and that this inactive form could be reactivated by an ATP dependent process (Rossini and Liao, 1982). However, there was no direct evidence provided that the ligand binding capacity is related to phosphorylation of the androgen receptor protein itself, although models were proposed in which androgen receptor phosphorylation was assumed to be essential for ligand binding (Rossini, 1984).

All the non-phosphorylated androgen receptor molecules synthesized in a cellfree system (reticulocyte lysate) were able to bind R1881 with similar affinity as receptors in target cells (Chapter 6). The fact that androgen receptors synthesized in reticulocyte lysate bind ligand, makes it also unlikely that phosphorylation of a putative target cell co-factor is essential for acquisition of ligand binding capacity.

\subsubsection{Heterogeneity of the androgen receptor and DNA binding}

Since both isoforms of the androgen receptor protein in $\mathrm{LNCaP}$ cells undergo transformation to the tight nuclear binding form, it is unlikely that phosphorylation is essential for DNA/chromatin binding by the receptor (Chapter

3). However, the possibility that both isoforms bind to different acceptor sites 
in the nucleus cannot be excluded. The human androgen receptor synthesized in vitro displayed specific binding to ARE/GRE containing oligonucleotides in an electrophoretic mobility shift assay (Chapter 6). The affinity of the androgen receptor for these oligonucleotides was rather low. Only in the presence of specific androgen receptor antisera stable complexes could be detected (Chapter 6). The androgen receptor antibodies probably stimulate. dimerization of the androgen receptor protein, thus enabling high affinity DNA binding. The low DNA binding affinity of the in vitro synthesized androgen receptor could in principle be due to the absence of phosphorylation or the presence in reticulocyte lysate of an inhibitor. In experiments using nuclear extracts of LNCaP cells in electrophoretic mobility shift assays, it was also impossible to detect specific complexes with GRE/ARE oligonucleotides. Only after the addition of specific androgen receptor antisera, stable complexes were detected (unpublished results). The androgen receptor in nuclear extracts is phosphorylated (Chapters 3 and 4), and lack of phosphorylation, is therefore, probably not the cause of the low DNA binding affinity. Moreover, Palvimo et al. (1993) showed specific binding of in vitro synthesized rat androgen receptor protein to the GRE/ARE from the tyrosine aminotransferase gene promoter in mobility shift assays. Complexes with DNA were already observed in the absence of androgen receptor antibodies. This is in contrast with the results described in Chapter 6. The reason for this discrepancy is at present unknown.

\subsubsection{Role of basal androgen receptor phosphorylation}

The role of the basal androgen receptor phosphorylation has not been elucidated. It is also not clear why only a part of the receptor population undergoes basal phosphorylation (Chapter 5). The basal phosphorylation is a rapid process (Chapter 3), and most likely occurs in the cytoplasm, before receptor 
translocation to the nucleus. It is possible that the unliganded androgen receptor is only a substrate for kinase(s) during synthesis or during a short period after synthesis, when the receptor is probably not yet associated with heat-shock proteins. The detection of both isoforms could reflect the existence of phosphorylation and dephosphorylation events, causing constant interconversion of both isoforms. The possible existence of such a cycle, however, was not confirmed in chase experiments after labeling of androgen receptors in LNCaP cells with $\left[{ }^{35} \mathrm{~S}\right]$-methionine. The rate of disappearance of the $112 \mathrm{kDa}$ isoform was 2-3 h, while the rate of disappearance of the $110 \mathrm{kDa}$ isoform was $<15$ min. (Kuiper et al.,1992). This indicates only phosphorylation of androgen receptor protein (110 $\mathrm{kDa}$ to $112 \mathrm{kDa}$ conversion), and no dephosphorylation. Or, alternatively, the protein half-life of the $110 \mathrm{kDa}$ isoform is very short in comparison with that of the phosphorylated $112 \mathrm{kDa}$ isoform. It should be noted that many proteins contain phosphorylated serine or threonine residues whose function does not appear to require reversible regulation. These phosphate groups turn over with the same half-life as the protein itself, and probably have a structural role. One could hypothesize that phosphorylation increases the halflife of androgen receptor protein in LNCaP cells. There is evidence that modulation of substrate proteins by covalent modifications, changes in hydrophobicity, and interactions with proteins or allosteric factors, may change the susceptibility of proteins to proteolysis and thereby functions to regulate protein degradation in the cell (Beynon, 1980; Holzer, 1980). It has been demonstrated that phosphorylation of serine residues reduces the sensitivity of polypeptides to proteolytic digestion (Holzer,1980). A possible influence of phosphorylation on androgen receptor stability can only be proven beyond doubt, after identification of all phosphorylation sites followed by measurement of the protein half-life of specific phosphorylation site mutants. 


\subsection{Hormone-stimulated androgen receptor phosphorylation}

The androgen receptor in $\mathrm{LNCaP}$ cells is already phosphorylated in the absence of hormone, and undergoes a hormone-stimulated additional phosphorylation. After incubation with R1881, an almost 2-fold increase in the phosphorylation degree over non-stimulated control cells was reached (van Laar et al.,1991). Similar results, that is a basal level of phosphorylation which was increased by incubation with mibolerone, were obtained after overexpression of the androgen receptor in Spodoptera frugiperda (Sf9) cells, using the baculovirus system (Alarifi et al.,1994). In Chapters 4 and 5, the hormone-stimulated phosphorylation was investigated in more detail. The hormone-stimulated phosphorylation is a rapid process, indicating that it does not require de novo protein synthesis (Chapter 4). A 1.8 fold stimulation was observed for the non-transformed androgen receptor (Chapter 4). For the transformed androgen receptor the stimulation factor is not known, since there are no androgen receptors present in the high salt nuclear extract of non-hormone incubated cells. The mean phosphorylation degree of transformed and untransformed receptors is the same after incubation with hormone (Chapter 4). This indicates that there is no direct causal link between hormone-stimulated phosphorylation and transformation to the tight nuclear binding form.

Part of the androgen receptor transformation process consists of the dissociation of receptor associated heat-shock proteins. Upon incubation of LNCaP cells with $\mathrm{R} 1881$ at $37^{\circ} \mathrm{C}$, most hsp90 is dissociated from the receptor within $3 \mathrm{~min}$ (Veldscholte et al., 1992). Thus the dissociation of heat-shock proteins is much faster than the increase in phosphorylation (Chapter 4), so that the substrate for the kinase(s) involved is the receptor free from heat-shock proteins. In fact, transformation as a whole is for most receptors a much faster process than the hormone-stimulated extra phosphorylation. Ultimately, about $40 \%$ of the total 
amount of the androgen receptor in LNCaP cells becomes transformed, and within 10 min of incubation with R1881 about $70 \%$ of that maximum is already reached (Veldscholte et al.,1992). Phosphorylation of transformed receptors continues to increase after 10 min incubation with R1881, indicating that at least a part of the extra phosphorylation of the transformed receptors occurs after chromatin binding (Chapter 4). Consequently, there could exist a difference in the phosphorylation pattern between transformed and untransformed receptors, despite the fact that both receptor types are phosphorylated to the same degree. In COS cells, hormone treatment induces an extra receptor isoform with an apparent molecular mass of $114 \mathrm{kDa}$, resulting in a 110-112-114 kDa triplet on SDS-PAGE (Jenster et al., 1994). Mutations in the DNA binding domain caused a reduction in the amount of the $114 \mathrm{kDa}$ isoform upon treatment of COS cells with R1881, indicating that part of the extra phosphorylation is influenced by the ability of the receptor to bind to DNA (Jenster et al., 1994). After incubation with R1881, a substantial amount of the $110 \mathrm{kDa}$ non-phosphorylated isoform is still present (Chapter 5). This accounts for the transformed as well as for the untransformed receptors (Chapter 3). Whether there is a functional difference between both isoforms (phosphorylated versus non-phosphorylated) of the transformed receptor is at present unknown. Also, after prolonged incubation of LNCaP cells with R1881 (12-16 h), still both isoforms were detected (Chapter 5). In another study, involving incubation of LNCaP cells with mibolerone for up to $49 \mathrm{~h}$, both isoforms were detected on immunoblots (Krongrad et al.,1991). For some proteins, multisite and hierarchal protein phosphorylation has been described (Roach, 1991). Whether such a hierarchy also exists for the androgen receptor, in a sense that only the basal phosphorylated receptor protein is a substrate for the hormone-stimulated extra phosphorylation, is presently unknown. 


\subsection{Identification and functional role of androgen receptor phosphorylation sites}

By using limited proteolysis of purified ${ }^{32} \mathrm{P}$-labeled androgen receptors it was established that most, if not all, phosphorylation sites are located in the $\mathrm{N}$ terminal domain. This accounts for the basal and the hormone-stimulated phosphorylation sites (Chapter 4). Only phosphorylation on serine residues was detected (Chapter 5). Many, but not all consensus phosphorylation sites for various kinases, known to phosphorylate nuclear proteins on serine residues, are located in the $\mathrm{N}$-terminal domain of the androgen receptor protein (see Table 7.1). From a comparison of many phosphoproteins it is known that multiple phosphorylation sites tend not to be randomly distributed, but are usually concentrated in relatively short segments of protein molecules. Often, these phosphorylated regions are located at the extreme amino- or carboxyl termini of proteins (Roach, 1991). The $\mathrm{N}$-terminal domain phosphorylation of the androgen receptor in LNCaP cells was confirmed in experiments involving the expression of androgen receptor mutants in COS cells (Jenster et al., 1994; Zhou et al., 1994). These studies provided evidence for phosphorylation at serine residues 80 and 93 , besides phosphorylation at other unknown sites in COS cells. Serine residues 80 and 93 are part of a Ser-Pro-X-X motif, which is recognized by the Ser-Pro directed kinase ( Vulliet et al.,1989). The Ser-Pro-X-X and Thr-Pro-X-X motifs are found much more frequently in gene regulatory proteins (such as homeotic gene proteins, segmentation gene proteins, steroid hormone receptor proteins, and certain oncogene proteins) than in DNA binding proteins that are not directly involved in gene regulation (such as the core histones) and also more frequently than in general proteins (Suzuki et al.,1989). Within the steroid/thyroid hormone receptor superfamily these motifs are not located in the zinc fingers and only seldom in the ligand binding region, but preferably in the 


\section{Table 7.1 POTENTIAL SERINE PHOSPHORYLATION SITES IN}

THE HUMAN ANDROGEN RECEPTOR

\begin{tabular}{|c|c|c|}
\hline Protein kinase & Consensus recognition motif & Potential sites in AR \\
\hline Casein kinase $\Pi$ & Ser-X-X-Glu/Asp & $\begin{array}{l}29 \\
118 \\
217 \\
255^{*} \\
290 \\
299 \\
641^{*} \\
653 \\
694\end{array}$ \\
\hline $\begin{array}{l}\text { cAMP-dependent } \\
\text { protein kinase }\end{array}$ & Arg-X-X-Ser & $\begin{array}{l}16^{*} \\
212^{*}\end{array}$ \\
\hline $\begin{array}{l}\text { DNA-dependent } \\
\text { protein kinase }\end{array}$ & $\begin{array}{l}\text { Ser-GIn in a } \\
\text { non-basic region }\end{array}$ & 114 \\
\hline $\begin{array}{l}\text { Ser-Pro directed } \\
\text { kinase }\end{array}$ & Ser-Pro-X & $\begin{array}{l}80 \\
93 \\
255^{*} \\
307 \\
506 \\
641^{*}\end{array}$ \\
\hline Protein kinase $\mathrm{C}$ & Lys/Arg-X-X-Ser & $\begin{array}{l}16^{*} \\
212^{*} \\
241\end{array}$ \\
\hline
\end{tabular}

* denotes serine residues which are part of the recognition motif of more than one kinase.

There are 17 potential phosphorylation sites for these kinases, of which 14 are located in the $\mathrm{N}$-terminal domain (exon 1, amino acid residues $1-528$ ).

Protein kinase consensus specificity motifs were obtained from Pearson and Kemp (1991) and Finnie et al., (1993).

The amino acid residue numbering is based on an AR cDNA coding for 910 amino acid residues, with 20 glutamine residues and 16 glycine residues in exon 1 (Faber et al., 1989). 
hypervariable $\mathrm{N}$-terminal domain or in the hinge region connecting the zinc fingers and the ligand binding domain. The strong evolutionary conservation in the otherwise variable N-terminus emphasizes the importance of these Ser-Pro motifs. Serine residue 114 of the human androgen receptor is within a consensus sequence for DNA dependent protein kinase (Table 7.1). DNA dependent protein kinase is a DNA-binding protein, and is active in vitro only when bound to the same DNA molecule as the substrate (Jackson et al., 1993). It has been suggested that restricting phosphorylation to DNA-bound substrates might be a mechanism to activate transcription factors only when they are ready to engage in transcription activation (Jackson et al., 1993). Whether the DNA bound androgen receptor protein is phosphorylated by DNA dependent protein kinase is unknown. Nine potential phosphorylation sites for casein kinase II can be found in the androgen receptor protein (Table 7.1). Casein kinase II is a ubiquitous cyclic nucleotide-independent protein kinase, and it has been reported to be activated by insulin, insulin-like growth factor, and epidermal growth factor (Pinna, 1990). Of the steroid hormone receptors only the estrogen receptor is known to be phosphorylated in vivo by casein kinase II (Arnold et al., 1994).

The N-terminal region of the androgen receptor, shown to be the predominant phosphorylated part of the androgen receptor, is essential for transcription activation (Jenster et al.,1991). There are some examples in which phosphorylation has been implicated in regulating the activity of transcription factors. One of the best examples of this type of regulation is provided by the transcription factor CREB (cAMP responsive element binding protein), which mediates transcription in response to activation of the cAMP-dependent protein kinase (PK-A) signal transduction pathway. PK-A appears to stimulate the transactivation capacity of CREB by phosphorylating CREB in a domain required for transcriptional activity (Gonzalez and Montminy, 1989). In addition, 
phosphorylation in or around the trans-activation domains of the human serum response factor protein, the CREM $\tau$ protein (cAMP responsive element modulator), and human c-myc, directly influence the trans-activation potential of these transcription factors (de Groot et al., 1993; Henriksson et al.,1993; Liu et al., 1993). The observation that negatively charged amino acid residues are important for the activity of many transcriptional activation domains, suggests that phosphorylation simply operates by adding extra negative charge (Ptashne, 1988). Indeed, the N-terminal trans-activation domain of the human androgen receptor is very hydrophilic and rich in acidic amino acid residues, especially between residues 100 and 325 (Faber et al.,1989), and phosphorylation in this area could add extra negative charge.

By tryptic phosphopeptide analysis it was shown that the androgen receptor contains multiple phosphorylation sites, and that R1881 treatment strongly stimulates the phosphorylation of one peptide, with only minor effects on other phosphopeptides (Chapter 5). Perhaps, this extra hormone-induced phosphorylation causes a major conformational change in the $\mathrm{N}$-terminal domain, thus enabling protein-protein contacts between the $\mathrm{N}$-terminal trans-activation domain and other transcription factors or coactivators on a target gene promoter, causing transcription induction. Evidence for such a model has been provided for the CREB protein, which after phosphorylation at serine residue 133 by protein kinase A undergoes a major conformational change, enabling interaction with CBP (CREB binding protein) which itself interacts with TFIIB and the RNA polymerase II holoenzyme (Arias et al., 1994; Kwok et al., 1994; Nordheim, 1994). Identification of all androgen receptor phosphorylation sites and subsequent site-directed mutagenesis is obviously essential. Unfortunately, microsequencing of several phosphopeptide peaks from the elution profile of the reverse phase separation analysis (Chapter 5, Figure 4), revealed that the samples were heterogenous, and therefore, sequences could not be determined 
(not shown). Since the amount of androgen receptor protein which can be purified from LNCaP cells is rather limited, a more rigorous purification of androgen receptor phosphopeptides is only possible after overexpression of androgen receptor protein in yeast or insect cells. Androgen receptor protein from these cells, purified to near homogeneity, could then be mixed with a small amount of $\left[{ }^{32} \mathrm{P}\right]$-labeled androgen receptor protein from $\mathrm{LNCaP}$ cells, followed by digestion with trypsin. Sequential cleavage of purified phosphopeptides with other protease(s), and re-purification by reverse phase HPLC could then provide material suitable for microsequencing and identification of phosphorylation sites. Functional studies on the role of phosphorylation of specific sites in androgen receptor action on the regulation of target genes, could then be undertaken. 


\section{REFERENCES}

Alarifi, A., Beitel, L.K., Alvarado, C., Farid, N.R., Pinsky, L. and Trifiro, M. (1994) Phosphorylation of human androgen receptor expressed at high levels using the baculovirus system. Abstract nr. 1423, The Endocrine Society 76th Annual meeting, Anaheim, USA.

Arias, J., Alberts, A.S., Brindle, P., Claret, F.X., Smeal, T., Karin, M., Feramisco, J. and Montminy, M. (1994) Activation of cAMP and mitogen responsive genes relies on a common nuclear factor. Nature $\underline{370}, 226-229$.

Arnold, S.F., Obourn, J.D., Jaffe, H. and Notides, A.C. (1994) Serine 167 is the major estradiol-induced phosphorylation site on the human estradiol receptor. Mol. Endocrinol. 8, $1208-1214$.

Berns, E., de Boer, W. and Mulder, E. (1986) Androgen-dependent growth regulation of and release of specific proteins by the androgen receptor containing human prostate tumor cell line LNCaP. The Prostate 9, 247-259.

Beynon, R.J. (1980) Protein modification and the control of intracellular protein degradation. In: The enzymology of post-translational modification of proteins. $1,363-385$.

Blackshear, P.J. (1984), Systems for polyacrylamide gel electrophoresis. Methods Enzymol. 104, 237-254.

Buchkovich, K., Duffy, L. and Harlow, E. (1989) The retinoblastoma protein is phosphorylated during specific phases of the cell cycle. Cell $\underline{58}$, 1097-1106.

Denison, S.H., Sands, A. and Tindall, D.J. (1989) A tyrosine aminotransferase glucocorticoid response element also mediates androgen enhancement of gene expression. Endocrinology 124, 1091-1093.

Driscoll, W.J., Lee, Y.C. and Strott, C.A. (1991) Adrenocortical pregnenolone binding protein activity requires a small heat-stable factor: evidence that regulation by phosphorylation/ dephosphorylation occurs at the level of the factor, not the protein. Mol. Endocrinol. $\underline{5}$, 1229-1238.

de Groot, R.P., den Hertog, J., Vandenheede, J.R., Goris, J. and Sassone-Corsi, P. (1993) Multiple and cooperative phosphorylation events regulate the CREM activator function. EMBO J. 12, 3903-3911.

Faber, P.W., Kuiper, G., van Rooij, H., van der Korput, J., Brinkmann, A.O. and Trapman,J. (1989) The N-terminal domain of the human androgen receptor is encoded by one, large exon. Mol.Cell.Endocrinol. 61, 257-262.

Finnie, N., Gottlieb, T., Hartley, K. and Jackson, S.P. (1993) Transcription factor phosphorylation by the DNA-dependent protein kinase. Biochem. Soc. Tr. 21 , 930-935.

Gaddipati, J., Mcleod, D., Heidenberg, H., Sesterhenn, I., Finger, M., Moul, J. and Srivastava,S. (1994) Frequent detection of codon 877 mutation in the androgen receptor gene in advanced prostate cancers. Cancer Research 54, 2861-2864.

Gonzalez, G.A. and Montminy, M.R. (1989) Cyclic AMP stimulates somatostatin gene transcription by phosphorylation of CREB at serine 133. Cell 59, 675-680.

Gould, K.L., Woodgett, J.R., Cooper, J.A., Buss, J.E., Shalloway, D. and Hunter, T. (1985) Protein kinase $C$ phosphorylates pp60 c-src at a novel site. Cell, 42 , 849-857.

Henriksson, M., Bakardjiev, A., Klein, G. and Luscher, B. (1993) Phosphorylation sites mapping in the $\mathrm{N}$-terminal domain of $\mathrm{c}-m y \mathrm{c}$ modulate its transforming potential. Oncogene $\underline{8}, 3199-3209$. 
Hereld, D., Vaughan, R., Kim, J.Y., Borleis, J. and Devreotes,P. (1994) Localization of ligand-induced phosphorylation sites to serine clusters in the C-terminal domain of the Dictyostelium cAMP receptor. J. Biol. Chem. 269, 7036-7044.

Holzer,H. (1980) Control of proteolysis. Ann.Rev.Biochem. 49, 63-91.

Horoszewicz, J.S., Leong, S.S., Kawinski, E., Karr, J., Rosenthal, H., Chu, T.M., Mirand, E.A. and Murphy, G.P. (1983) LNCaP model of human prostate carcinoma. Cancer Research 43 , 1809-1818.

Jackson, S., Gottlieb, T. and Hartley, K. (1993) Phosphorylation of transcription factor Sp1 by the DNA-dependent protein kinase. Adv. Sec. Messenger Phosphopr. Res. 28, 279-286.

Jenster, G., van der Korput, H., van Vroonhoven, C., van der Kwast, Th., Trapman, J. and Brinkmann, A.O. (1991) Domains of the human androgen receptor involved in steroid binding, transcriptional activation and subcellular localization. Mol.Endocrinol. $\underline{5}$, 13961404.

Jenster, G., de Ruiter, P., van der Korput, J., Kuiper, G., Trapman, J. and Brinkmann, A.O. (1994) Changes in abundance of androgen receptor isotypes: effects of ligand treatment, glutamine stretch variation, and mutation of putative phosphorylation sites. Biochemistry 33, 14064-14072.

Krongrad, A., Wilson, C.M., Wilson, J.D., Allman, D.R. and McPhaul, M.J. (1991) Androgen increases androgen receptor protein while decreasing receptor mRNA in LNCaP cells. Mol.Cell.Endocrinol. 76, 79-88.

Kuiper, G., de Ruiter, P.E. and Brinkmann, A.O. (1992) Androgen receptor heterogeneity in LNCaP cells is caused by a hormone independent phosphorylation step.

J.Steroid Biochem.Mol.Biol. $\underline{41}$, 697-700.

Kwok, R., Lundblad, J., Chrivia, J.C., Richards, J., Bachinger, H., Brennan, R., Roberts, S., Green, M.R. and Goodman, R.H. (1994) Nuclear protein CBP is a coactivator for the transcription factor CREB. Nature $370,223-226$.

Lee, Y.C., Oeda, T., Driscoll, W.J., Fales, H.M. and Strott, C.A. (1992) Purification and identification of the heat stable factor required for pregnenolone binding protein activity. Evidence that the factor is adenosine-3'-5'-diphosphate. J.Biol.Chem. 267, 10982-10987.

Liu, S.H., Ma, J.T., Yueh, A.Y., Lees-Miller, S.P., Anderson, C.W. and Ng, S.Y. (1993) The carboxyl terminal transactivation domain of human serum response factor contains DNAactivated protein kinase phosphorylation sites. J.Biol.Chem. 268, 21147-21154.

Nordheim, A. (1994) CREB takes CBP to tango. Nature 370, 177-178.

Palvimo, J.J., Kallio, P.J., Ikonen, T., Mehto, M. and Jänne, O.A. (1993) Dominant negative regulation of transactivation by the rat androgen receptor: roles of the $\mathrm{N}$-terminal domain and heterodimer formation. Mol.Endocrinol. 7, 1399-1407.

Pearson, R.B. and Kemp, B.E. (1991) Protein consensus phosphorylation site sequences and consensus specificity motifs. Meth. Enzymol. 200, 62-79.

Pinna, L.A. (1990) Casein kinase II: an eminence grise in cellular regulation. Biochim. Biophys. Acta 1054, 267-284.

Ptashne, M. (1988) How eukaryotic transcriptional activators work. Nature 335, 683-689.

Riegman, P., Vlietstra, R., van der Korput, H., Brinkmann, A.O. and Trapman,J. (1991) The promoter of the prostate specific antigen gene contains a functional androgen responsive element. Mol.Endocrinol. 5, 1921-1930.

Ris-Stalpers, C., Verleun-Mooijman, M., Trapman, J. and Brinkmann, A.O. (1993) Threonine on amino acid position 868 in the human androgen receptor is essential for androgen binding specificity and functional activity. Biochem.Biophys.Res.Commun. 196, 173-180. 
Ris-Stalpers, C., Hoogenboezem, T., Sleddens, H., Verleun-Mooijman, M., Degenhart, H., Drop, S., Halley, D., Oosterwijk, J., Hodgins, M., Trapman, J. and Brinkmann, A.O. (1994) A practical approach to the detection of androgen receptor gene mutations and pedigree analysis in families with X-linked androgen insensitivity. Pediatric Research 36, 227-234.

Roach, P.J. (1991) Multisite and hierarchal protein phosphorylation. J.Biol.Chem. 266, 1413914142 .

Rossini, G.P. and Liao, S. (1982) Intracellular inactivation, reactivation and dynamic status of prostate androgen receptors. Biochem. J. 208, 383-392.

Rossini, G.P. (1984) Steroid receptor recycling and its possible role in the modulation of steroid hormone action. J.Theor.Biol. 108, 39-53.

Schuurmans, A.L.G., Bolt, J., Voorhorst, M., Blankenstein, M.A. and Mulder; E. (1988) Regulation of growth and epidermal growth factor receptor levels of LNCaP prostate tumor cells by different steroids. Int.J.Cancer $\underline{42}$, 917-922.

Suzuki, H., Sato, N., Watabe, Y., Masai, M., Seino, S. and Shimazaki, J. (1993) Androgen receptor gene mutations in human prostate cancer. J.Steroid Biochem.Molec.Biol. 46, 759765 .

Suzuki, M. (1989) SPXX, a frequent sequence motif in gene regulatory proteins. J.Mol.Biol. 207, 61-84.

Swinnen, J.V., Esquenet, M., Heyns, W., Rombatts, W. and Verhoeven, G. (1994) Androgen regulation of the messenger RNA encoding diazepam-binding inhibitor/acyl-CoA binding protein in the human prostatic adenocarcinoma cell line LNCaP. Mol.Cell. Endocrinol. 104, 153-162.

van Laar, J.H., Bolt-de Vries, J., Zegers, N.D., Trapman, J. and Brinkmann, A.O. (1990) Androgen receptor heterogeneity and phosphorylation in human LNCaP cells. Biochem.Biophys.Res.Commun. 166, 193-200.

van Laar, J., Berrevoets, C., Trapman, J., Zegers, N.D. and Brinkmann, A.O. (1991) Hormone dependent androgen receptor phosphorylation is accompanied by receptor transformation in human Lymph Node Carcinoma of the Prostate cells. J.Biol.Chem. 266, 3734-3738.

van Steenbrugge, G.J, van Uffelen, C.J.C., Bolt, J. and Schröder, F.H. (1991) The human prostatic cancer cell line LNCaP and its derived sublines: an in vitro model for the study of androgen sensitivity. J.Steroid.Biochem.Mol.Biol. 40, 207-214.

Veldscholte, J., Voorhorst-Ogink, M., Bolt, J., van Rooij, H., Trapman, J. and Mulder,E. (1990A) Unusual specificity of the androgen receptor in the human prostate tumour cell line LNCaP: high affinity for progestagenic and estrogenic steroids. Biochim. Biophys. Acta 1052, 187-194.

Veldscholte, J., Ris-Stalpers, C., Kuiper, G., Jenster, G., Berrevoets, C., Claassen, E., van Rooij, H., Trapman, J., Brinkmann, A.O. and Mulder, E. (1990B) A mutation in the ligand binding domain of the androgen receptor of human LNCaP cells affects steroid binding characteristics and response to anti-androgens. Biochem.Biophys.Res.Commun. $\underline{173}$, 534-540.

Veldscholte, J., Berrevoets, C.A., Zegers, N.D., van der Kwast, Th. H., Grootegoed, J.A. and Mulder, E. (1992) Hormone-induced dissociation of the androgen receptor heat-shock protein complex: use of a new monoclonal antibody to distinguish transformed from nontransformed receptors. Biochemistry $\underline{31}, 7422-7430$.

Vulliet, P., Hall, F., Mitchell, J. and Hardie, D.G. (1989) Identification of a novel prolinedirected serine/threonine protein kinase in rat pheochromocytoma. J.Biol.Chem. 264, 16292-16298. 
Warrian, N., Page, N., Koutsilieris, M. and Govindan, M. (1994) Antiandrogens inhibit human androgen receptor dependent gene transcription in the human prostate cancer cells LNCaP. The Prostate 24, 176-186.

Zhou, Z-X., Wong, C-I., Sar, M, and Wilson, E.M. (1994) The androgen receptor. Rec.Progr.Horm.Res. 49, 249-274. 


\section{CURRICULUM VITAE}

De schrijver van dit proefschrift werd geboren op 23 mei 1961 te Maastricht. Na het behalen van het HAVO diploma aan het R.K. Veldeke College te Maastricht volgde hij de HBO-B opleiding tot analist aan het Van ' $t$ Hoff Instituut te Rotterdam. Vanaf 1 mei 1984 was hij werkzaam als analist binnen het Instituut Endocrinologie \& Voortplanting van de Erasmus Universiteit te Rotterdam. Vanaf september 1985 volgde hij tevens de deeltijd studie Biologie aan de Rijksuniversiteit te Utrecht. Het doctoraal examen met als hoofdvak Moleculaire Biologie werd afgelegd in september 1991. Vanaf 1 september 1991 tot 1 september 1994 was hij als wetenschappelijk onderzoeker werkzaam binnen het Instituut Endocrinologie \& Voortplanting van de Faculteit der Geneeskunde en Gezondheidswetenschappen van de Erasmus Universiteit te Rotterdam, alwaar het in dit proefschrift beschreven onderzoek werd verricht. Sinds 1 januari 1995 is hij werkzaam binnen het Center for Biotechnology (CBT), Karolinska Institute, te Huddinge, Zweden, op basis van een NWO stipendium. 



\section{NAWOORD}

In tegenstelling tot wat de enkele naam op de kaft doet veronderstellen, is dit proefschrift het resultaat van de inspanning van meerdere mensen. Ik ben aan veel mensen dank verschuldigd, waarvan ik er hier een aantal met naam wil noemen. Allereerst mijn co-promotor en begeleider in de afgelopen jaren, Albert Brinkmann. Albert, ik heb van jou geleerd wat wetenschappelijk onderzoek is, hoe het moet en hoe het niet moet. Je hebt me altijd geholpen, ook wanneer ik wel eens een beetje te eigenwijs was. Petra de Ruiter verdient bijzondere vermelding voor de goede uitvoering van een deel van de experimenten en de praktische ondersteuning bij de promotie, en alles wat daar zoal bij komt kijken. Mijn promotor, Anton Grootegoed dank ik voor het in mij gestelde vertrouwen, de discussies en goede suggesties. Een woord van dank dient ook uit te gaan naar de huidige en oud-medewerkers van "Androdroom". Ik dank Eppo Mulder, Joan Bolt, Els Berns, Willem de Boer, Alex Schuurmans, Marleen Voorhorst, Jos Veldscholte, Guido Jenster, Coos van Laar, Carrie Ris, Cor Berrevoets, Cor Kuil, Hennie Brüggenwirth, Marja Verleun, Annemie Boehmer, Annelies van der Linden, Theo Hoogenboezem, Erna Langeler en Pieter de Lange voor de gezelligheid, goede werksfeer en ondersteuning.

Ik denk nog steeds met veel plezier terug aan de tijd die ik heb mogen doorbrengen bij de groep van Jan Trapman in de vakgroep Pathologie. In september 1987 cloneerden Paul Klaassen, Jan Trapman en ikzelf (eigenlijk veel meer Paul en Jan dan ik), een "stukje DNA met een zink vinger". Een aantal maanden later bleek dat we inderdaad het zo fel begeerde androgeen receptor cDNA te pakken hadden. Het is goed om te zien dat de samenwerking tussen "de vijfde en de tiende" die zo klein begonnen is, nog steeds bestaat en zijn niet geringe vruchten afwerpt. Ik bedank bij deze Jan Trapman, Peter Riegman, Henri van Rooij, Hetty van der Korput, Paul Klaassen, Remco Vlietstra, Peter 
Faber en Hans Bluyssen voor de prettige samenwerking.

Tenslotte wens ik het Instituut Endocrinologie \& Voortplanting en alle medewerkers het allerbeste in de toekomst. 